\title{
Map and Data for Quaternary Faults and Fault Systems on the Island of Hawai'i
}

Prepared as part of the U.S. Geological Survey's Earthquake Hazards Program project to compile a Map of Quaternary Faults and Folds of the United States

Open-File Report 2007-1284 


\section{Map and Data for Quaternary Faults and Fault Systems on the Island of Hawai'i}

By Eric C. Cannon, Roland Bürgmann, Anthony J. Crone, Michael N. Machette, and Richard L. Dart

Open-File Report 2007-1284 


\title{
U.S. Department of the Interior DIRK KEMPTHORNE, Secretary
}

\author{
U.S. Geological Survey \\ Mark D. Myers, Director
}

\section{U.S. Geological Survey, Reston, Virginia: 2007}

For product and ordering information:

World Wide Web: http://www.usgs.gov/pubprod

Telephone: 1-888-ASK-USGS

For more information on the USGS--the Federal source for science about the Earth, its natural and living resources, natural hazards, and the environment:

World Wide Web: http://www.usgs.gov

Telephone: 1-888-ASK-USGS

Any use of trade, product, or firm names is for descriptive purposes only and does not imply endorsement by the U.S. Government.

Although this report is in the public domain, permission must be secured from the individual copyright owners to reproduce any copyrighted materials contained within this report.

Suggested citation:

Cannon, E.C., Bürgmann, R., Crone, A.J., Machette, M.N., and Dart, R.L., 2007, Map and data for Quaternary faults and fault systems on the Island of Hawai'i: U.S. Geological Survey Open-File Report 2007-1284,

81 p., 1 plate. 


\section{Contents}

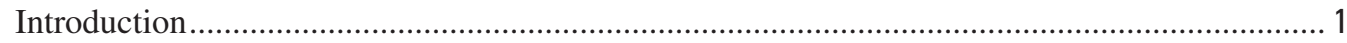

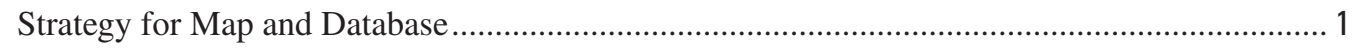

Overview of Quaternary Faults on the Island of Hawai 'i .............................................................. 4

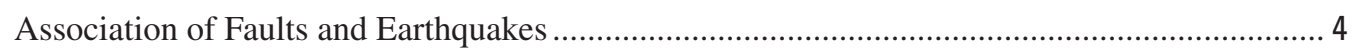

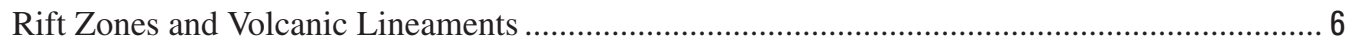

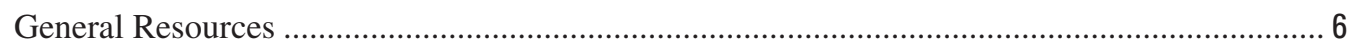

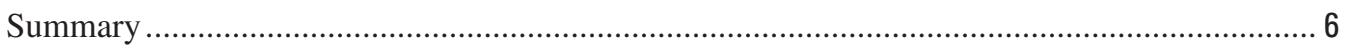

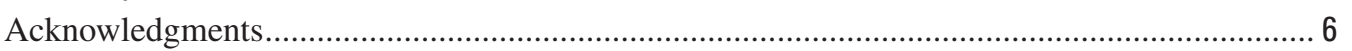

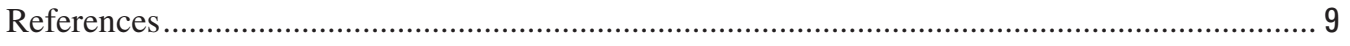

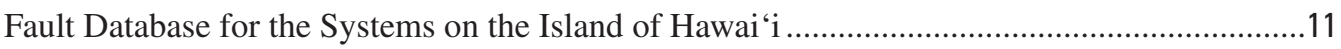

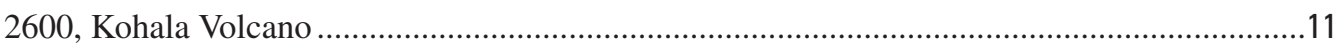

2600a, Northwest Volcanic Lineament, Kohala Volcano.................................................12

2600b, Southeast Volcanic Lineament, Kohala Volcano......................................................13

2600c, Kohala Graben Section, Kohala Volcano …….........................................................14

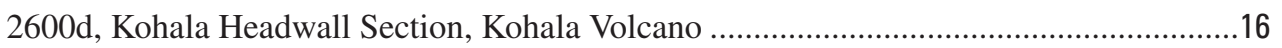

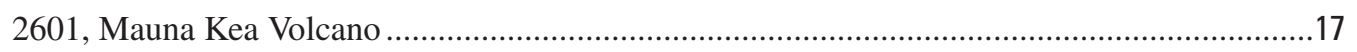

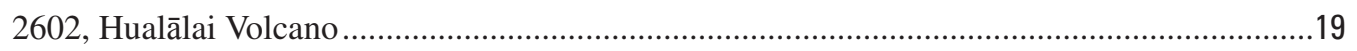

2602a, Northwest Volcanic Lineament, Hualālai Volcano .................................................20

2602b, North V olcanic Lineament, Hualālai Volcano ........................................................21

2602c, South-Southeast Volcanic Lineament, Hualālai Volcano .........................................23

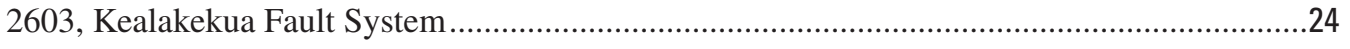

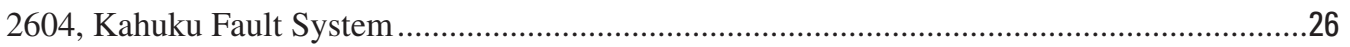

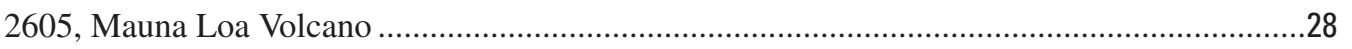

2605a, Moku ‘̄āweoweo Caldera, Mauna Loa Volcano ....................................................29

2605b, Northeast Rift Zone, Mauna Loa Volcano ………...................................................

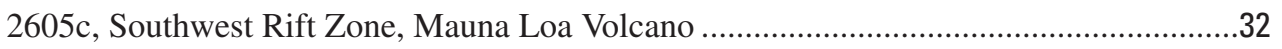

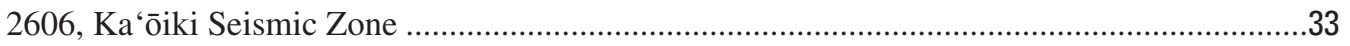

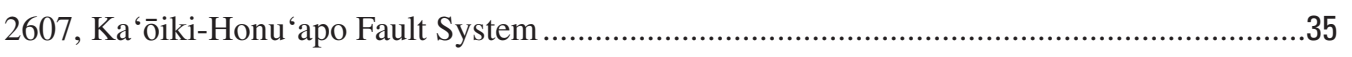

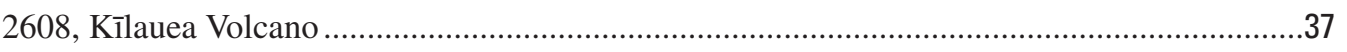

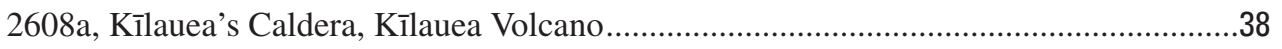

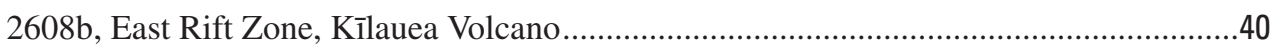

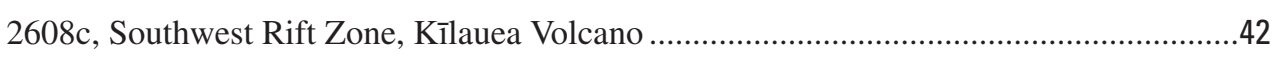

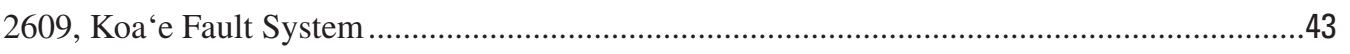

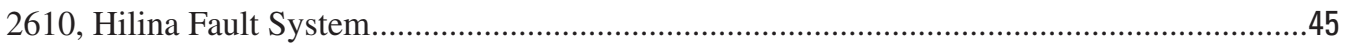

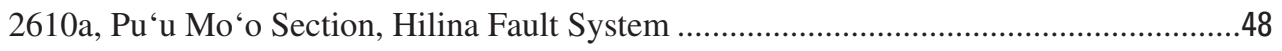

2610b, Kūkalau ‘ula Pali Section, Hilina Fault System....................................................

2610c, Hilina Pali Section, Hilina Fault System............................................................5

2610d, Keana Bihopa Section, Hilina Fault System …….................................................

2610e, Pu ‘u Ka'one Section, Hilina Fault System .............................................................

2610f, Pu ‘u Kapukapu Section, Hilina Fault System ..........................................................

2610g, Makahanu Pali Section, Hilina Fault System........................................................55

2610h, Pu 'u 'eo Pali Section, Hilina Fault System..............................................................56 
2610i, Kīpukapapālinamoku Section, Hilina Fault System ..................................................58

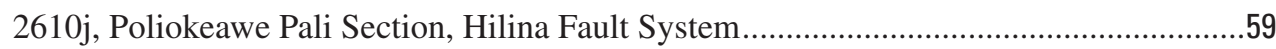

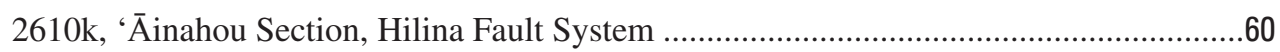

26101, Hōlei Pali Section, Hilina Fault System ..............................................................62

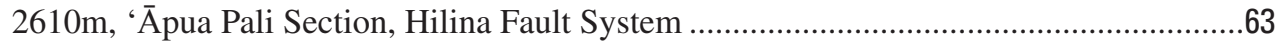

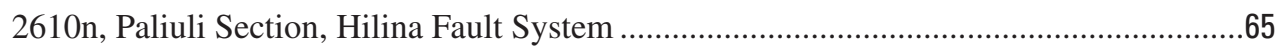

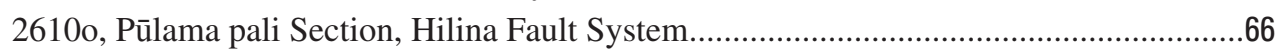

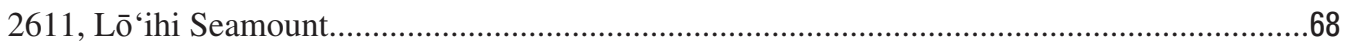

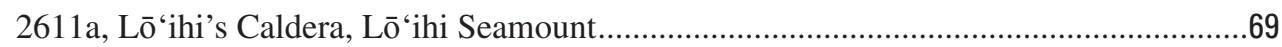

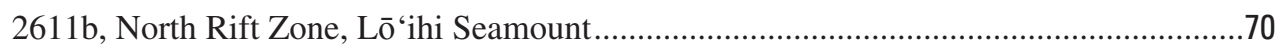

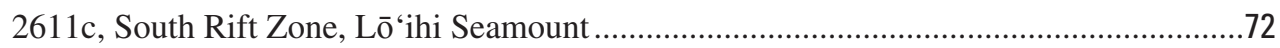

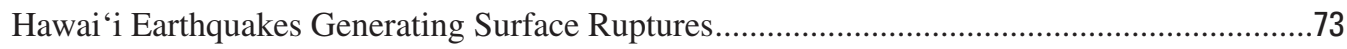

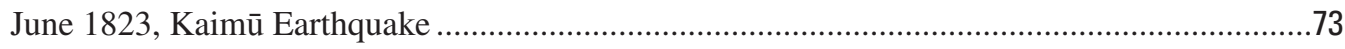

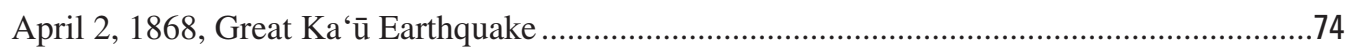

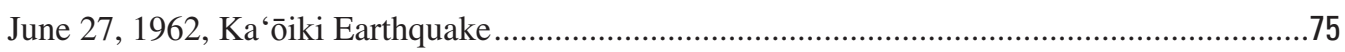

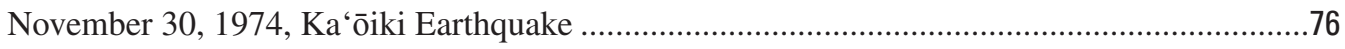

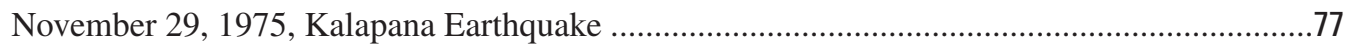

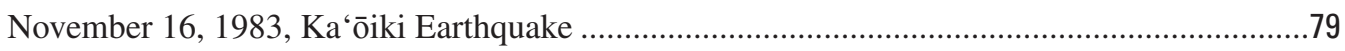

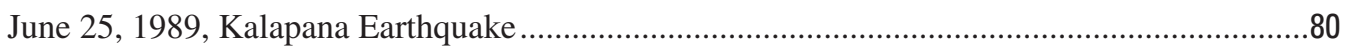

\section{Plate}

Plate 1. Map of Quaternary Faults and Fault Systems on the Island of Hawai 'i .........Attached

\section{Figures}

1. Generalized map of active faults, rift zones, and volcanic lineaments for Hawai ' 1 i............. 7

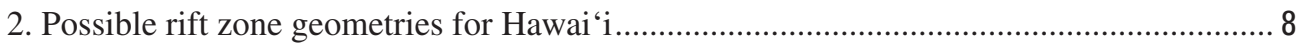

3. Location map of the Hilina fault system [2610] showing its 15 sections ...........................45

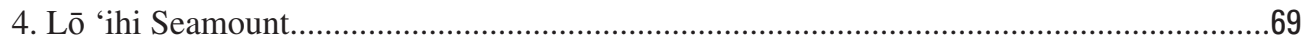

\section{Table}

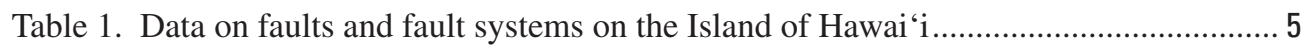




\title{
Map and Data for Quaternary Faults and Fault Systems on the Island of Hawai'i
}

\author{
By Eric C. Cannon, ${ }^{1}$ Roland Bürgmann, ${ }^{2}$ Anthony J. Crone, ${ }^{3}$ Michael N. Machette, ${ }^{4}$ and Richard L. Dart ${ }^{3}$ \\ Prepared as part of the U.S. Geological Survey's Earthquake Hazards Program project to compile a Map of Quaternary \\ Faults and Folds of the United States
}

\section{Introduction}

The World Map of Major Active Faults Task Group is compiling a series of digital maps for the United States and other countries in the Western Hemisphere that show the locations, ages, and activity rates of major earthquake-related features such as faults and fault-related folds; the companion database includes published information on these seismogenic features. While the Western Hemisphere effort is sponsored by International Lithosphere Program (ILP) Task Group II-2, the effort to compile a new map and database for the United States is funded by the U.S. Geological Survey's (USGS) Earthquake Hazards Program (EHP). The maps and accompanying databases were key contributions to the Global Seismic Hazards Assessment Program (ILP Task Group II-0) for the International Decade for Natural Disaster Reduction.

Guidelines for the compilation of the Quaternary fault and fold maps for the United States were published by Haller and others (1993) at the onset of this project. The compilation of Quaternary surface faulting and folding in Hawai' $i$ is one of several similar state and regional compilations that were planned for the United States. Reports published to date include West Texas (Collins and others, 1996), New Mexico (Machette and others, 1998), Arizona (Pearthree, 1998), Colorado (Widmann and others, 1998), Montana (Stickney and others, 2000), Idaho (Haller and others, 2005), and Washington (Lidke and others, 2003). Reports for other states such as California and Alaska are still in preparation.

This compilation is presented as a digitally prepared map product and catalog of data, both in Adobe Acrobat PDF format. The catalog provides referenced data on a variety of

\footnotetext{
${ }^{1}$ Present address: 7350 Bulen Drive, Anchorage, AK 99507; eccannon@gmail.com.

${ }^{2}$ Department of Earth and Planetary Science, University of CaliforniaBerkeley, Berkeley, CA 94720-4767; burgmann@seismo.berkeley.edu.

${ }^{3}$ U.S. Geological Survey, P.O. Box 25046, MS 966, Denver, CO 80225-0046; crone@usgs.gov; dart@usgs.gov.

${ }^{4}$ U.S. Geological Survey, P.O. Box 25046, MS 980, Denver, CO 80225-0046; machette@usgs.gov.
}

geographic, geologic, and paleoseismologic parameters related to surface faulting. The senior authors (Eric C. Cannon and Roland Bürgmann) compiled the fault data as part of ongoing studies of active faulting on the Island of Hawai' $i$. The USGS is responsible for organizing and integrating the State or regional products under their National Seismic Hazard Mapping project, including the coordination and oversight of contributions from individuals and groups (Michael N. Machette and Anthony J. Crone), database design and management (Kathleen M. Haller), and digitization and analysis of map data (Richard L. Dart). After being reviewed and released to the public as an Open-File Report, the data will become available online at http://earthquake.usgs.gov/regional/ qfaults/, the USGS Quaternary Fault and Fold Database of the United States.

\section{Strategy for Map and Database}

The primary intention of this compilation is to be used in seismic-hazard evaluations. In regions of low to moderate seismicity, it is particularly important to incorporate geologic information on discrete faults that have evidence of Quaternary movement because the historical record of earthquakes may be too short to identify all hazardous structures. Paleoseismic studies, which evaluate the history of surface faulting or deformation along a given structure, provide a long-term perspective that helps augment the relatively short records of historical seismicity in many regions. In particular, the frequency and location of large-magnitude earthquakes in many parts of the United States are poorly defined by the record of historical seismicity. Thus, knowledge of the seismogenic characteristics of prehistoric (Quaternary) faults can contribute to improved seismic-hazard assessments in critical regions of low to moderate historical seismicity.

The map and database are designed to accommodate information for well-studied faults in the United States; that is, those that have been the subject of extensive geologic and paleoseismic investigations. However, the bulk of seismogenic structures are only poorly studied, thus resulting in the 
appearance that the database is incomplete (for example, there may be unnamed faults, empty data fields, or sparse descriptions). Nevertheless, the fault map and database parameters provide a consistent framework for which these structures can be assessed as potential seismic sources and yet allow us to add information as new studies are completed. The database is dynamic and will be augmented and updated through time; this report is the first iteration of the data for the Island of Hawai' $i$.

The map (pl. 1) shows faults, volcanic rift zones, and lineaments that show evidence of Quaternary surface movement related to faulting, including data on the time of most recent movement, sense of movement, slip rate, and continuity of surface expression. The landform base image is a 10-m digital elevation model (DEM) from the State of Hawaii ( $h t t p / /$ www.soest.hawaii.edu/coasts/data/hawaii/dem.html). Fault traces were primarily from a 1:100,000-scale geologic map of Hawai 'i compiled by Wolfe and Morris (1996), available in digital format from Trusdell and others (2006). The traces were loaded into Arc/Info-geographic information system ${ }^{1}$ (GIS) software that permits rescaling, output in a variety of projections, and the ability to assign attributes to specific features (colors, line weights, and symbols). In addition to the location and style of faulting, the map shows the time of most recent movement and slip-rate category (as a proxy for fault activity) for each structure. These data, as well as name and affiliation of the compiler, date of compilation, and geographic and other paleoseismologic parameters are in the database. Published data or publicly available data (EHP contract reports, theses, etc.) are referenced extensively throughout the report. On the computer version of the database (http://earthquake.usgs.gov/regional/qfaults/), the user can search for data in a specific field or a combination of fields.

For purposes of map presentation, the time of the most recent fault movement (that is, surface rupture) is shown as one of five categories: historic ( $<150$ years with specific date), Holocene and latest Pleistocene ( $<15 \mathrm{ka})$, late Quaternary $(<130 \mathrm{ka})$, late and middle Quaternary $(<750 \mathrm{ka})$, and Quaternary or suspected Quaternary ( $<1.6 \mathrm{Ma})$. Of these categories, only the first four are represented on this map (that is, all but Quaternary or suspected Quaternary) in the colors red, orange, yellow, and blue, respectively. These categories define a maximum time of movement without constraining the minimum time, which typically requires more detailed studies. This strategy allows estimates to be made where published data are sparse or where there are conflicts in evidence for timing. For example, if Holocene or latest Pleistocene $(<15 \mathrm{ka})$ movement is suspected but only late Pleistocene (15-130 ka) movement can be documented, then the inclusive late Quaternary $(<130 \mathrm{ka})$ category is used for the time of the most recent movement. For this map, several faults are known to have had surface-rupturing earthquakes in historic time. In addition to

\footnotetext{
${ }^{1}$ Use of trade or brand names, such as Arc/Info, is for descriptive purposes and does not constitute endorsement by the U.S. Geological Survey or the Department of Interior.
}

known surface faults, some Quaternary faults that are suspected or inferred from topography or other data are shown as dotted lines (that is, buried structures).

In the Quaternary fold and fault database, individual features have been traditionally assigned to one of four fault categories (Classes A-D) based on demonstrable evidence or non-evidence of Quaternary tectonic movements (known or presumed to be associated with large-magnitude earthquakes). These classes were developed for features whose movement is driven by purely tectonic forces, such as those that result from plate-boundary movements. However, the forces that cause movement on structures in Hawai'i result from a combination of magmatic and gravitational processes that are different from those forces driven by plate tectonics that cause movement on nonvolcanogenic structures. Even though the structures in Hawai' $i$ are associated with brittle deformation in the form of ground cracks, fissure vents, dike injection, normal faulting, and basal detachment faulting, the driving forces and origin of the structures are distinctly different from purely tectonic faults. Given these significant differences, for this compilation, we do not assign the structures in Hawai' $i$ to the classes that have been used for other structures described in the Quaternary fault and fold database.

We graphically represent the slip rate on features in plate 1 by different line thickness, and use slip rate as a proxy for fault activity. The four slip rate categories comprise all geologic slip rates on a national scale and have been defined for this project as: less than $0.2 \mathrm{~mm} / \mathrm{yr}, 0.2-1 \mathrm{~mm} / \mathrm{yr}, 1-5 \mathrm{~mm} / \mathrm{yr}$, and greater than $5 \mathrm{~mm} / \mathrm{yr}$. Rift zones, which are typically broad zones of deformation (fissures, fractures, faults, and eruptive vents), and volcanic lineaments, inferred from the alignment of volcanic cones on topographic ridges, are shown by special symbols different from the more easily depicted faults (pl. 1). Slip rate is not indicated for rift zones and volcanic lineaments; their ages of movement are indicated by the color scheme given above.

Many faults for the Island of Hawai ' $i$ are characterized by published or inferred slip rates of less than $5 \mathrm{~mm} / \mathrm{yr}$, but faults in the southeastern part of the island [2605, 2606, 2608, 2609,2610 , and 2611] have published or inferred rates of $>5 \mathrm{~mm} / \mathrm{yr}$ owing to rapid southeast-directed extension and active volcanic activity. If no published slip rate exists (that is, "unknown"), the compiler assigned the fault to an appropriate slip-rate category as determined from his or her impressions of the activity based on geologic data for this and other associated structures in the region. Assigning a feature to a unique slip-rate category is required in order to portray the feature with a specific line thickness. Where available, the length of time for which the estimated slip rate applies is shown in the database. The absence or presence of recent movement over some time interval may be a basis for estimating a crude slip rate, and one can use a variety of geomorphic and geologic relations to place a fault in its most likely most recent movement (time) category. For example, a normal fault that does not cut latest Pleistocene (10-15 ka) deposits probably has an average slip rate of less than $1 \mathrm{~mm} / \mathrm{yr}$ because during this time 
interval (10-15 k.y.) at least $10-15 \mathrm{~m}$ of potential slip would be expected to accumulate, yielding an average rate of $1 \mathrm{~mm} /$ yr or greater. This amount of accumulated slip most likely would be released in several large surface-rupturing earthquakes. An exception to this generalization is faults that show evidence of temporal clustering; that is, episodes of movement (several faulting events) separated by longer intervals of tectonic quiescence. In such cases, the average slip rate could be considerably less than that calculated for an intracluster interval of time. This scenario is becoming more apparent in the literature as researchers conduct paleoseismic studies of faulting, especially in intraplate regions.

The database includes several fields that contain supporting information on the previously mentioned parameters, as well as additional descriptive information on geologic and paleoseismologic parameters not shown on the map. The descriptive information includes fault name and number, a brief synopsis, compilation information, and physical location of the structure. Because the USGS's Quaternary fault and fold compilation is integrating data from the entire United States, the database requires that each structure have a unique number (in the text, a fault's number is enclosed by square brackets, such as [2600]). In general, most of the structures in a given state or region are sequentially numbered on a geographic basis. Names are determined from the literature and/ or common usage. Some structures in different regions have the same name or a similar name, and no attempt was made to avoid such duplications. Geologic data include geologic setting, geomorphic expression, and age of faulted deposits, all in descriptive form. Additional paleoseismologic data include descriptions of detailed studies (for example, trenching) that we are aware of and estimates of recurrence intervals. Database field names are shown in bold and are defined in the online database (or see general guidelines published by Haller and others, 1993). The computer database version allows users to search for data in a specific field or a combination of fields. Fields that cannot be searched, such as "Comments," document the source of data as well as any provisions that might exist about its use.

Compilations such as this one provide a useful tool for making comparisons of spatial and temporal patterns of faulting at local, regional, and national scales. However, a database is a powerful tool only if it represents a systematic collection of data, which must inherently rely heavily on the knowledge of the compiler. With this in mind, we favor published or publicly accessible data and reference it as completely as possible. An effort has been made to include all pertinent data, especially where conflicts may be apparent. Where multiple interpretations exist in the literature, we use a hierarchy that defines what data will be presented in the primary database fields in order to achieve some level of consistency. We give highest priority to fault-related studies, particularly those addressing the Quaternary history of a fault (that is, paleoseismic investigations) over general geologic studies (for example, bedrock mapping). In most cases, more recent studies are given priority, although some older studies (pre-1970s) are quite helpful and authoritative. Fault data based on detailed mapping (for example, 1:24,000 scale) are given priority over those based on less detail (for example, 1:100,000 or 1:250,000 scale). Even though we give the most weight to recent topical studies of Quaternary faulting (that is, paleoseismology), alternative interpretations based on other types of studies are provided in the appropriate "Comments" field.

The majority of the twelve Quaternary faults and fault systems that we describe for the Island of Hawai' $i$ have received a limited amount of study, most of which have not been specifically oriented toward paleoseismology; however, as previously mentioned, the database is designed for well-studied faults in regions of high seismicity and historical faulting, such as California and Nevada. Two faults, the east [2608b] and southwest [2608c] rift zones of Kīlauea Volcano, have strong evidence of ongoing deformation based on data from geodetic monitoring. In order to accommodate large differences in the level of study from fault to fault, we established three types (simple, sectioned, and segmented) to simplify data compilation and readily convey the level of current knowledge. All structures in Hawai' $i$ are described as either simple faults or faults having sections.

In general, simple faults are poorly known, have few or no paleoseismologic studies, are characterized by a single time and slip-rate category for their entire length, and are typically less than 20-30 km in length. Sectioned faults are described as having geomorphic, geometric, or possible behavioral characteristics that suggest separate movement histories, although there typically are not enough detailed studies to prove such independence. At the other end of the spectrum are segmented faults - those composed of seismogenic and structural entities (segments) that are known to act independently of one another during large surface-rupturing earthquakes on the basis of detailed studies. By our standards and definitions, the time of surface-rupturing events on segments of a fault must be well established through trenching and dating studies or through the presence of historical surface ruptures. Also, there should be supporting geomorphologic and geologic data (scarp morphology, stratigraphic control on times of faulting, geologic structures that may control physical segmentation, etc.). In some cases, there are pronounced contrasts in the geomorphic expression of faulting exist along strike. This evidence and the paleoseismic studies that define the chronology of the youngest events are sufficient to discuss the structure in terms of individual segments. The term "segments" is popular but ambiguous because it has been applied to different kinds of segments (structural, geomorphic, rupture, behavioral, and others). Because of this ambiguity, we avoid using the term "segments" in this compilation; we use instead the term "sectioned" for those faults that were previously labeled "segmented." No faults on the Island of Hawai ' $i$ are described as having segments, but six of the 12 faults are described as having sections, particularly the Hilina fault system, which we subdivide into 15 sections. Sections can be defined on the basis of relative-age criteria; by fault geometry; by the presence, morphology, or preservation of scarps; from 
a single trench; or from other geologic data (gravity, structure, etc.). Altogether, the 12 faults and fault systems comprise 37 separate but related structures (faults and fault sections). The six simple faults (not subdivided into sections) are shown on the map and listed in the database by a four-digit numeric identifier (for example, [2601]). The six sectioned faults are identified by an additional lowercase alpha character ([2600a], [2600b], [2600c], etc.). The alpha characters are unique to each fault; the first letter $(a)$ is assigned to the northernmost or westernmost section (depending on the orientation of the sections), and the last letter ( $c$ in this example) is assigned to the southernmost or easternmost section.

\section{Overview of Quaternary Faults on the Island of Hawai' $i$}

The Island of Hawai ' $\mathrm{i}$ is the southeasternmost and youngest island in the Hawaiian-Emperor island-seamount chain. The island is composed of five subaerial volcanoes (fig. 1): Kohala Volcano has not been active in the Holocene, Mauna Kea Volcano last erupted approximately 4,000 years ago, Hualālai Volcano last erupted in 1800-1801, Mauna Loa Volcano last erupted in 1984, and Kīlauea Volcano is active and began its most recent eruptive cycle in 1983. Lō'ihi Seamount is an active submarine volcano located southeast of the Island, the youngest seamount in the island-seamount chain.

The Island of Hawai'i has 12 Quaternary fault systems related to its volcanoes (fig. 1, table 1). The following list gives brief summaries of the makeup of each fault system:

- Kohala Volcano [2600]. The fault system comprises the (a) northwest and (b) southeast volcanic lineaments, (c) the northwest-trending Kohala graben, and (d) a headscarp to a major submarine landslide off northeast Hawai' $i$.

- Mauna Kea Volcano [2601]. The system's scattered volcanic cones do not form well-defined volcanic lineaments.

- Hualālai Volcano [2602]. The (a) northwest, (b) north, and (c) south-southeast volcanic lineaments.

- Kealakekua fault system [2603]. The headscarp to a major submarine landslide offshore of western Hawai'i.

- Kahuku fault system [2604]. A normal fault system located on the southwestern flank of the Mauna Loa Volcano.

- Mauna Loa Volcano [2605]. A (a) summit caldera and the (b) northeast and (c) southwest rift zones.

- Ka'ōiki seismic zone [2606]. A seismically active zone displaying en echelon, left-stepping fractures, and right-lateral strike-slip motion, located on the southeastern flank of Mauna Loa Volcano.

- Ka'öiki-Honu'apo fault system [2607]. An extensional fault system situated on the southeastern flank of Mauna Loa Volcano.

- Kîlauea Volcano [2608]. A (a) summit caldera and the (b) east and (c) southwest rift zones.

- Koa'e fault system [2609]. An extensional fault system situated between Kīlauea's caldera and Kîlauea's mobile south flank.

- Hilina fault system [2610]. A long normal-fault system on Kīlauea's south flank; subdivided into 15 sections.

- Lo' 'ihi Seamount [2611]. A (a) summit caldera and the (b) north and (c) south rift zones located on the submarine volcano.

\section{Association of Faults and Earthquakes}

Seismicity and faulting on the Island of Hawai' $i$ and in other volcanic systems result from magmatic and gravitational processes and are responsible for building and destroying the volcanic edifice. Buoyant magma rises from depth and builds a volcanic edifice atop the ocean floor overlain by pelagic sediments (see Hill and Zucca, 1987). Magma is stored in the summit magma reservoir or emplaced into vertically-oriented rift zones through dike injection, then subsequently erupted onto the surface. Commonly one side of the rift zone is buttressed against an adjacent volcano while the opposite side of the rift zone, an unbuttressed flank, faces the sea. As dikes are injected into the rift zone, the rift zone extends and widens and the volcano grows by gravitational spreading (Fiske and Jackson, 1972). Large magnitude earthquakes can occur when accumulated stress from rift zone dike injections is released through the lateral sliding of the unbuttressed volcanic flank along the basal detachment, or decollement, the boundary lubricated by weak pelagic sediments between the volcanic edifice and the oceanic lithosphere. (For examples of such large-magnitude earthquakes, see the 1975 M7.2 Kalapana and $1868 \sim \mathrm{M} 8$ Great Ka' $\mathrm{u}$ earthquakes; Tilling and others, 1976; Lipman and others, 1985; Wyss, 1988.) In general, the earthquake faults described in this compilation are probably secondary structures activated by either (a) major faulting on the basal detachment, or (b) changes in magma reservoir volumes.

Surface deformation commonly associated with rift zones includes fissure vents, ground cracks, and normal faults with graben-style structures. Inflation and deflation of magma reservoirs produce ground cracks and fissure vents at the summit region. Major eruptions can produce caldera-concentric normal faults around steep caldera and crater walls. An 
Table 1. Data on faults and fault systems on the Island of Hawai 'i. Main fault zones or fault systems are shown in bold type. [MRE, time of most recent surface-faulting event; Ma, millions of years ago; ka, thousands of years ago; SR, slip-rate category in $\mathrm{mm} / \mathrm{yr}$.]

\begin{tabular}{|c|c|c|c|}
\hline No. & Name of structure & MRE & SR \\
\hline 2600 & Kohala Volcano & & \\
\hline $2600 \mathrm{a}$ & Northwest volcanic lineament & $<750 \mathrm{ka}$ & $<0.2$ \\
\hline $2600 b$ & Southeast volcanic lineament & $<750 \mathrm{ka}$ & $<0.2$ \\
\hline $2600 c$ & Kohala graben section & $<750 \mathrm{ka}$ & $<0.2$ \\
\hline $2600 d$ & Kohala headwall section & $<750 \mathrm{ka}$ & $<0.2$ \\
\hline 2601 & Mauna Kea Volcano & $<1.6 \mathrm{Ma}$ & $<0.2$ \\
\hline 2602 & Hualālai Volcano & & \\
\hline $2602 \mathrm{a}$ & Northwest volcanic lineament & $<750 \mathrm{ka}$ & $<0.2$ \\
\hline $2602 b$ & North volcanic lineament & $<750 \mathrm{ka}$ & $<0.2$ \\
\hline $2602 c$ & South-southeast volcanic lineament & $<750 \mathrm{ka}$ & $<0.2$ \\
\hline 2603 & Kealakekua fault system & $<130 \mathrm{ka}$ & $<0.2$ \\
\hline 2604 & Kahuku fault system & $<130 \mathrm{ka}$ & $<0.2$ \\
\hline 2605 & Mauna Loa Volcano & & \\
\hline $2605 a$ & Moku‘āweoweo caldera & Historic (1880-1984) & $>5$ \\
\hline $2605 b$ & Northeast rift zone & Historic (1843-1984) & $>5$ \\
\hline $2605 c$ & Southwest rift zone & Historic (1868-1984) & $>5$ \\
\hline 2606 & Ka'ōiki seismic zone & Historic $(1974,1983)$ & $>5$ \\
\hline 2607 & Ka'ōiki-Honu'apo fault system & $<15 \mathrm{ka}$ & $1-5$ \\
\hline 2608 & Kīlauea Volcano & & \\
\hline $2608 \mathrm{a}$ & Kīlauea's caldera & $<15 \mathrm{ka}$ & $>5$ \\
\hline $2608 b$ & East rift zone & Historic (1989) & $>5$ \\
\hline $2608 \mathrm{c}$ & Southwest rift zone & Historic (1983) & $>5$ \\
\hline 2609 & Koa'e fault system & Historic (1975) & $>5$ \\
\hline 2610 & Hilina fault system & & \\
\hline $2610 \mathrm{a}$ & Pu'u Mo'o section & $<15 \mathrm{ka}$ & $1-5$ \\
\hline $2610 b$ & Kūkalau'ula Pali section & Historic (1975) & $1-5$ \\
\hline $2610 \mathrm{c}$ & Hilina Pali section & Historic (1975) & $>5$ \\
\hline $2610 d$ & Keana Bihopa section & Historic (1975) & $1-5$ \\
\hline $2610 \mathrm{e}$ & $\mathrm{Pu}^{\prime} \mathrm{u}$ Ka'one section & Historic (1975) & $1-5$ \\
\hline $2610 f$ & $\mathrm{Pu}$ 'u Kapukapu section & $<15 \mathrm{ka}$ & $>5$ \\
\hline $2610 \mathrm{~g}$ & Makahanu Pali section & $<15 \mathrm{ka}$ & $1-5$ \\
\hline $2610 \mathrm{~h}$ & $\mathrm{Pu}{ }^{\prime} \mathrm{u}^{\prime} e o$ Pali section & $<15 \mathrm{ka}$ & $>5$ \\
\hline $2610 \mathrm{i}$ & Kīpukapapālinamoku section & $<15 \mathrm{ka}$ & $1-5$ \\
\hline $2610 \mathrm{j}$ & Poliokeawe Pali section & Historic (1975) & $>5$ \\
\hline 2610k & 'Āinahou section & $<15 \mathrm{ka}$ & $1-5$ \\
\hline 26101 & Hōlei Pali section & Historic (1975) & $>5$ \\
\hline $2610 \mathrm{~m}$ & ‘Āpua Pali section & Historic (1975) & $1-5$ \\
\hline $2610 n$ & Paliuli section & $<15 \mathrm{ka}$ & $1-5$ \\
\hline 26100 & Pūlama pali section & $<15 \mathrm{ka}$ & $>5$ \\
\hline 2611 & Lō'ihi Seamount & & \\
\hline 2611a & Lō‘ihi’s caldera & Historic (1996) & $>5$ \\
\hline $2611 b$ & North rift zone & $<15 \mathrm{ka}$ & $>5$ \\
\hline $2611 \mathrm{c}$ & South rift zone & $<15 \mathrm{ka}$ & $>5$ \\
\hline
\end{tabular}


additional type of fracture observed on volcanic flanks are radial vents, fissure vents that trend radially away from volcanic summits rather parallel to rift zone axes.

Mass movement is another faulting mechanism. Slumping can occur on the steep walls of a volcano, a crater, a caldera, or cliffs, possibly induced by groundshaking caused by major earthquakes. Along steep coastlines, landslides that slump catastrophically into the ocean can generate tsunamis, as has been well documented on the Island of O'ahu (see Smith and others, 2002) and off the coast of the Island of Hawai ' $\mathrm{i}$ (Morgan and Clague, 2003; Morgan and others, 2003). The fault map (pl. 1) shows "Tsunami Evacuation Zones" in purple color along coastal areas. The zones are based on the probable inundation of low-lying areas and are taken from the Hawaiian government website (http://www.Hawaii.gov/dbedt/gis/download.htm, under the section "Hazard Layers: Tsunami Evacuation Zones"). Coastal normal fault systems are often associated with submarine mass movement features, indicating that the subaerial normal faults may represent landslide headscarps for larger submarine slumps and debris avalanches (Moore and others, 1989, 1995). Faulting may require triggering from a major earthquake. Also, depending on the depth and size of the fault systems, the faults may not be large enough to generate large earthquakes. Nonetheless, movement on coastal fault systems is a significant geologic process that shapes volcanoes in Hawai' 'i. Geodetic and seismic monitoring of volcanic systems are crucial for assessing the seismic hazards associated with earthquakes and faults on the Island of Hawai' $i$.

\section{Rift Zones and Volcanic Lineaments}

Wolfe and Morris (1996) categorize all subaerial volcanoes in Hawai' $i$ as being either shield-stage or postshield-stage. Shield-stage volcanoes are growing at their fastest rates, producing fluid tholeiitic basalt that erupts from the summit caldera and along rift zones. Rift zones of shield-stage volcanoes have fissure vents, open cracks, and normal faults along the rift zone axes. In subsequent postshield-stage volcanism, volcanic growth declines greatly with more viscous basalt, and rift zone activity declines and ceases. Wolfe and Morris (1996) limit the term "rift zone" to shield-stage Mauna Loa [2605] and Kīlauea [2608] Volcanoes. The term "volcanic lineament" is used in this compilation to describe alignments of volcanic cones along topographic ridges for postshield-stage Kohala [2600] and Hualālai [2602] Volcanoes. The distribution of volcanic cones on Mauna Kea [2601] is scattered, and we do not attempt to define volcanic lineaments on Mauna Kea in this compilation. Although postshield-stage volcanic cones aligned in lineaments indicate Quaternary brittle deformation, dike injections into shield-stage "rift zones" and gravitational spreading of the volcanic flanks most likely ceased around the time of transition from shield-stage to postshield-stage volcanism.

\section{General Resources}

Useful resources used in this compilation include the 1:100,000-scale geologic map of Hawai' $i$ compiled by Wolfe and Morris (1996), available in digital format from Trusdell and others (2006), and the USGS Professional Paper "Volcanism in Hawaii" (Decker and others, 1987). The U.S. Board of Geographic Names now allows for the use of diacritical marks-the glottal stop ( '), known as the 'okina or 'u'ina in Hawaiian, and the macron $\left({ }^{-}\right)$- in Hawaiian geographic names (Takahashi, 1987; Neal and Lockwood, 2003). Takahashi (1987) provides a thorough guide to the pronunciation and spelling of Hawaiian place names and words.

Wyss and Koyanagi (1992) provide detailed descriptions and damage reports for historic earthquakes in the Hawaiian Islands. For additional seismicity references, the Hawaiian Volcano Observatory (HVO) produces annual summaries of seismicity data (for example, Nakata, 2005). Klein and others (2000) develop seismic hazard maps for Hawai 'i. Many U.S. Geological Survey reports and maps used in this compilation are available free in electronic file format from the http://pubs. usgs.gov website.

\section{Summary}

Driven by magmatic and gravitational processes, the Quaternary faults of Hawai'i represent deformation of the volcanic edifice. The deformation on most Quaternary structures are considered to be related to slip triggered by large earthquakes or by magmatic activity. The Kỉlauea rift zones are currently the most active features on the island. The 1975 M7.2 Kalapana earthquake and $1868 \sim \mathrm{M} 8$ Great Ka'ū earthquakes (Tilling and others, 1976; Lipman and others, 1985; Wyss, 1988) were caused by the sudden and lateral displacement of volcanic flanks along the basal detachments, which in turn was caused by the release of stress accumulated by dike intrusions in volcanic rift zones. Coastal faults may also be expressed by subaerial headwall landslide scarps from submarine slumps and debris avalanches (see Moore and others, 1989, 1995), which can cause tsunamis. Continued monitoring of volcanic systems and earthquake faults will lead to a better understanding of their behavior and the hazards associated with the Quaternary faults on Hawai 'i.

\section{Acknowledgments}

The senior author (Cannon) completed this work as a derivative product of his M.S. Geology thesis at the University of California Davis, under the direction of Roland Bürgmann. U.S. Geological Survey authors appreciate the support of the Earthquake Hazards Program (EHP), which funded much of the work cited in this report, and the assistance of numerous individuals who either reviewed portions of the report or supplied information for the report. In particular, 


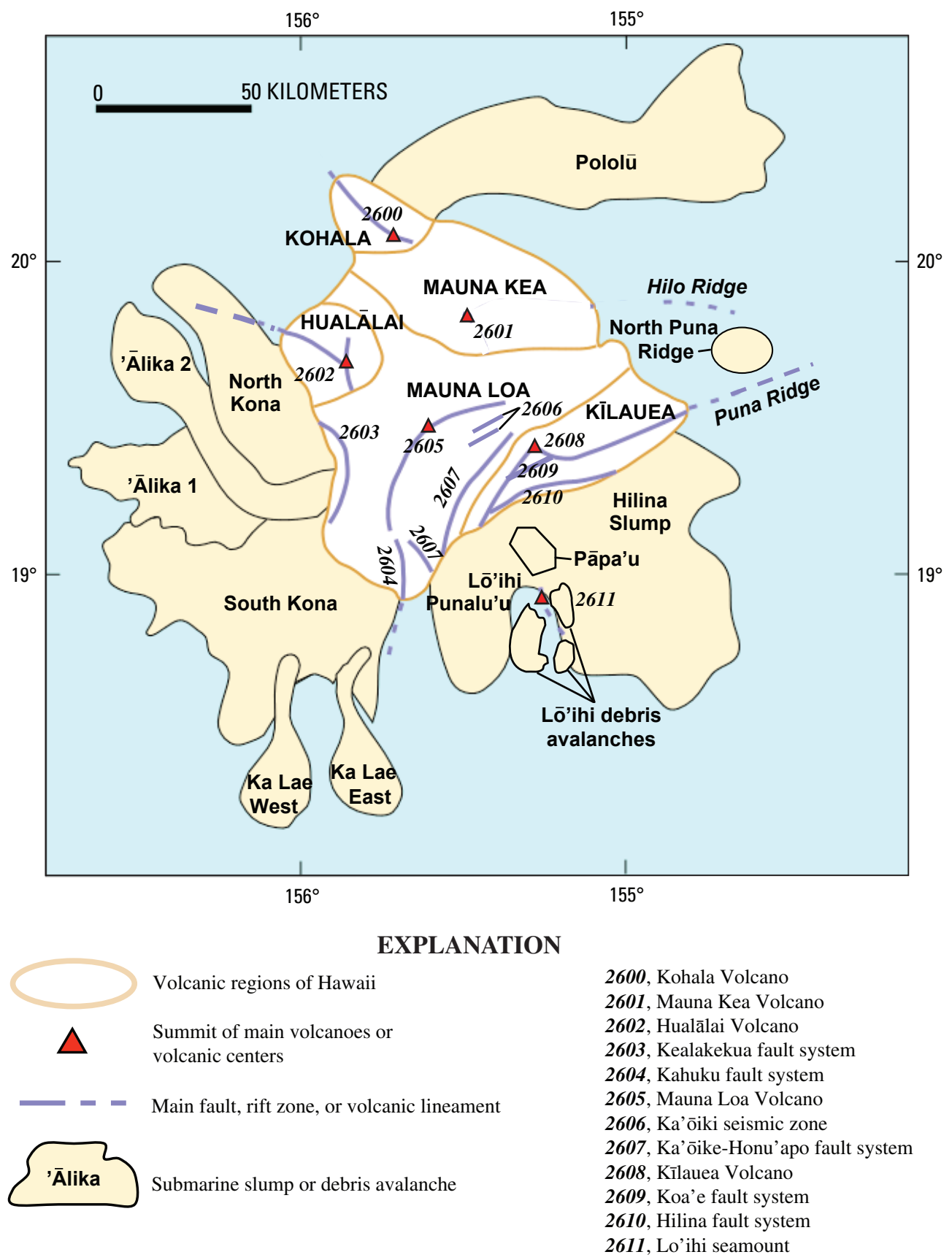

Figure 1. Generalized map of active faults, rift zones, and volcanic lineaments for Hawai' $i$. Modified from Peterson and Moore (fig. 7.2b, 1987) and Wolfe and Morris (fig. 1, 1996). Submarine slumps, debris avalanches, and rift zones taken from Fornari (1987), Moore and Chadwick (pl. 1, 1995), and Moore and others (fig. 1, 1995). List shows structure name and structure number as described in the fault database. 

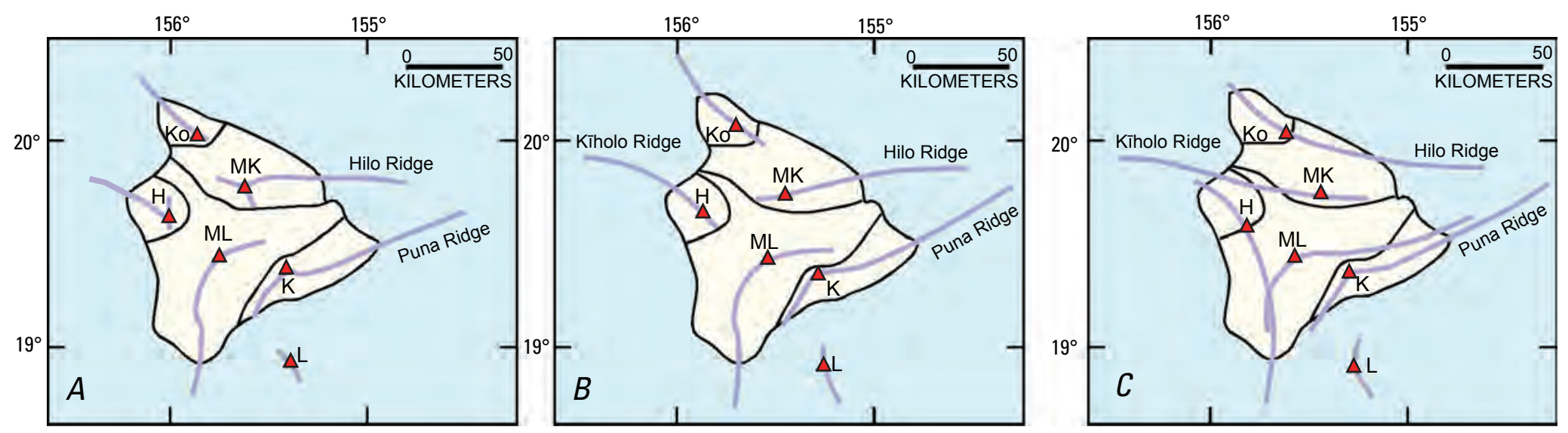

Figure 2. Possible rift zone geometries for Hawai'i. Volcanoes are abbreviated: (Ko) Kohala, (MK) Mauna Kea, (H) Hualālai, (ML) Mauna Loa, (K) Kīlauea, (L) Lō ‘ihi. Rift zones and volcanic lineaments are in purple. A, Modified from Peterson and Moore (fig. 7.2b, 1987), Fornari (1987), and Moore and Chadwick (pl. 1, 1995). B, Figure modified from Holcomb and others (2000). C, Alternate model from Holcomb and others (2000). 
we are grateful to Don Swanson (USGS-Hawaii Volcano Observatory) and Ed Wolfe (USGS-retired), who reviewed this report.

\section{References}

Collins, E., Raney, J.A., Machette, M.N., Haller, K.M., and Dart, R.L., 1996, Map and data for Quaternary faults in west Texas and adjacent parts of Mexico: U.S. Geological Survey Open-File Report 96-002, 74 p., 1 pl., scale 1:500,000.

Decker, R.W., Wright, T.L., and Stauffer, P.H., eds., 1987, Volcanism in Hawaii (2 vol.): U.S. Geological Survey Professional Paper 1350.

Fiske, R.S., and Jackson, E.D., 1972, Orientation and growth of Hawaiian volcanic rifts: The effect of regional structure and gravitational stresses: Proceedings of the Royal Society of London, v. 329, p. 299-326.

Fornari, D.J., 1987, The geomorphic and structural development of Hawaiian submarine rift zones, in Decker, R.W., Wright, T.L., and Stauffer, P.H., eds., Volcanism in Hawaii: U.S. Geological Survey Professional Paper 1350, v. 1, p. $125-132$.

Haller, K.M., Machette, M.N., and Dart, R.L., 1993, Maps of major active faults, Western Hemisphere, International Lithosphere Program (ILP) Project II-2-Guidelines for U.S. database and map: U.S. Geological Survey Open-File Report 93-338, 45 p.

Haller, K.M., Personius, S.F., Crone, A.J., Lidke, D.J., Machette, M.N., and Dart, R.L., 2005, Fault descriptions for the State of Idaho as part of the Quaternary fault and fold database of the United States: U.S. Geological Survey Open-File Report 2005-1047.

Hill, D.P., and Zucca, J.J., 1987, Geophysical restraints on the structure of Kilauea and Mauna Loa Volcanoes and some implications for seismomagmatic processes, in Decker, R.W., Wright, T.L., and Stauffer, P.H., eds., Volcanism in Hawaii: U.S. Geological Survey Professional Paper 1350, v. 2, p. 903-917.

Holcomb, R.T., Nelson, B.K., Reiners, P.W., and Sawyer, N.-L., 2000, Overlapping volcanoes-The origin of Hilo Ridge, Hawaii: Geology, v. 28, no. 6, p. 547-550.

Klein, F.W., Frankel, A.D., Mueller, C.S., Wesson, R.L., and Okubo, P.G., 2000, Seismic-hazard maps for Hawaii: U.S. Geological Survey Miscellaneous Investigations Series I-2724, 2 pls., scale 1:2,000,000.

Lidke, D.J., Johnson, S.Y., McCrory, P.A., Personius, S.F., Nelson, A.R., Dart, R.L., Bradley, L.-A., Haller, K.M., and Machette, M.N., 2003, Map and data for Quaternary faults and folds in Washington State: U.S. Geological Survey Open-File Report 03-428, 16 p., 1 pl., scale 1:750,000.
Lipman, P.W., Lockwood, J.P., Okamura, R.T., Swanson, D.A., and Yamashita, K.M., 1985, Ground deformation associated with the 1975 magnitude-7.2 earthquake and resulting changes in activity of Kilauea Volcano, Hawaii: U.S. Geological Survey Professional Paper 1276, 45 p.

Machette, M.N., Personius, S.F., Kelson, K.I., Haller, K.M., and Dart, R.L., 1998, Map and database of Quaternary faults and folds in New Mexico: U.S. Geological Survey Open-File Report 98-521, 443 p., 1 plate, scale 1:750,000.

Moore, J.G., Bryan, W.B., Beeson, M.H., and Normark, W.R., 1995, Giant blocks in the South Kona landslide, Hawaii: Geology, v. 23, no. 2, p. 125-128.

Moore, J.G., and Chadwick, W.W., Jr., 1995, Offshore geology of Mauna Loa and adjacent areas, Hawaii, in Rhodes, J.M., and Lockwood, J.P., eds., Mauna Loa revealed-Structure, composition, history, and hazards: American Geophysical Union Geophysical Monograph, v. 92, p. 21-44.

Moore, J.G., Clague, D.A., Holcomb, R.T., Lipman, P.W., Normark, W.R., and Torresan, M.E., 1989, Prodigious submarine landslides on the Hawaiian Ridge: Journal of Geophysical Research, v. 94, no. B12, p. 17,465-17, 484.

Morgan, J.K., and Clague, D.A., 2003, Volcanic spreading on Mauna Loa volcano, Hawaii-Evidence from accretion, alteration, and exhumation of volcaniclastic sediments: Geology, v. 31, no. 5, p. 411-414.

Morgan, J.K., Moore, G.F., and Clague, D.A., 2003, Slope failure and volcanic spreading along the submarine south flank of Kilauea volcano, Hawaii: Journal of Geophysical Research, v. 108, no. B9, p. 2,415.

Nakata, J.S., 2005, Hawaiian Volcano Observatory seismic data, January to December 2004: U.S. Geological Survey Open-File Report 2005-1315, 88 p.

Neal, C.A., and Lockwood, J.P., 2003, Geologic map of the summit region of Kīlauea Volcano, Hawaii: U.S. Geological Survey Geologic Investigations Series I-2759, 14 p., 1 sheet, scale 1:24,000.

Pearthree, P.A., 1998, Quaternary fault data and map for Arizona: Arizona Geological Survey Open-File Report 98-24, 122 p., 1 sheet, scale 1:750,000.

Peterson, D.W., and Moore, R.B., 1987, Geologic history and evolution of geologic concepts, Island of Hawaii, in Decker, R.W., Wright, T.L., and Stauffer, P.H., eds., Volcanism in Hawaii: U.S. Geological Survey Professional Paper 1350, v. 1, p. 149-189.

Smith, J.R., Satake, K., Morgan, J.K., and Lipman, P., 2002, Collapse features revealed by recent multibeam sonar surveys on the Hawaiian Ridge, in Takahashi, E., Lipman, P.W., Garcia, M.O., Nakata, J., and Aramaki, S., eds., Hawaiian volcanoes-Deep underwater perspectives: American Geophysical Union Monograph, v. 128, p. 11-28. 
Stickney, M.C., Haller, K.M., and Machette, M.N., 2000, Quaternary faults and seismicity in western Montana: Montana Bureau of Mines and Geology Special Publication 114, 1 sheet, scale 1:750,000.

Takahashi, T.J., 1987, Guide to pronunciation of Hawaiian words, in Decker, R.W., Wright, T.L., and Stauffer, P.H., eds., Volcanism in Hawaii: U.S. Geological Survey Professional Paper 1350, v. 2, p. 1,663-1,667.

Tilling, R.I., Koyanagi, R.Y., Lipman, P.W, Lockwood, J.P., Moore, J.G., and Swanson, D.A., 1976, Earthquake and related catastrophic events, Island of Hawaii, November 29, 1975-A preliminary report: U.S. Geological Survey Circular 740, 33 p.

Trusdell, F.A., Wolfe, E.W., and Morris, J., 2006, Digital database of the geologic map of the island of Hawai' $i$ : U.S. Geological Survey Data Series 144, supplement to Miscellaneous Investigations Series Map I-2524-A, 18 p., 1 sheet, scale 1:100,000.

Widmann, B.L., Kirkham, R.M., and Rogers, W.P., 1998, Preliminary Quaternary fault and fold map and database of Colorado: Colorado Geological Survey Open-File Report 98-8, 331 p., 1 pl., scale 1:500,000.

Wolfe, E.W., and Morris, J., 1996, Geologic map of the island of Hawaii: U.S. Geological Survey Miscellaneous Investigations Series Map I-2524-A, 18 p., 3 sheets, scale 1:100,000.

Wyss, M., 1988, A proposed source model for the Great Kau, Hawaii, Earthquake of 1868: Bulletin of the Seismological Society of America, v. 78, no. 4, p. 1,450-1,462.

Wyss, M., and Koyanagi, R.Y., 1992, Isoseismal maps, macroseismic epicenters, and estimated magnitudes of historic earthquakes in the Hawaiian Islands: U.S. Geological Survey Bulletin 2006, 93 p. 


\section{Fault Database for the Systems on the Island of Hawai' $i$}

The following discussion of Quaternary faults on the Island of Hawai' $i$ is organized by the number we have assigned to the structure. Generally speaking, the numbering scheme moves from north to south and west to east across the island. We list two values for the length of features: the end-to-end length is a measurement of the distance in a straight line between the two end-points of the feature, and the cumulative length is the sum of the lengths of individual strands of the feature. We also list two values for the average strike. The first value is the average strike of the feature with respect to a north direction. The second value is the average strike direction in a numerical format in which northeasterly strikes have a positive value and northwesterly strikes have a negative value.

\section{0, Kohala Volcano}

Structure number 2600 .

Comments: See figure 1 for location map of Kohala Volcano in the northern part of the Island of Hawai 'i.

Structure name Kohala Volcano.

Comments: Kohala Volcano is located on Sheet 1 of 3 of the 1:100,000-scale geologic map compiled by Wolfe and Morris (1996), available in digital format from Trusdell and others (2006).

Synopsis Kohala is the oldest volcano on the Island of Hawai 'i. It has two poorly defined volcanic lineaments inferred along broad topographic ridges: the northwest [2600a] and southeast [2600b] volcanic lineaments. These volcanic lineaments may follow the general trend of earlier shield-stage rift zones (fig. 2). At the summit region in the Kohala Mountains, the volcanic lineaments are co-located with the northwest-trending Kohala graben [2600c] (Wolfe and Morris, 1996). Along the northeast coast of the Kohala Peninsula, a coastal "headwall" [2600d] trends approximately northwest from Kukuihaele to Akokoa Point. The Kohala graben most likely is a pull-apart graben at the head of the $3,500 \mathrm{~km}^{2}$ Pololu submarine debris avalanche (fig. 1) (Moore and others, 1989).

Date of compilation September 16, 2006.

Compiler and affiliation Eric C. Cannon; Roland Bürgmann, University of California Berkeley.

Province Hawaiian-Emperor island-seamount chain.

Geologic setting Kohala is a postshield-stage volcano and is the northernmost and oldest volcano on Hawai $i$ with an approximate age of 120-700 ka (Wolfe and Morris, 1996).

Number of sections 4.

Comments: The four sections are the northwest [2600a] and southeast [2600b] volcanic lineaments, the Kohala graben [2600c], and the Kohala headwall [2600d].

Average strike (azimuth) N. $53^{\circ}$ W. $\pm 27^{\circ} ;-53^{\circ} \pm 27^{\circ}$.

Length (km) 35.9 (end to end); 116.0 (cumulative).

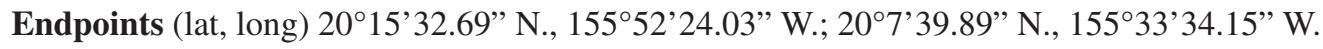

\section{References}

Moore, J.G., Clague, D.A., Holcomb, R.T., Lipman, P.W., Normark, W.R., and Torresan, M.E., 1989, Prodigious submarine landslides on the Hawaiian Ridge: Journal of Geophysical Research, v. 94, no. B12, p. 17,465-17,484.

Trusdell, F.A., Wolfe, E.W., and Morris, J., 2006, Digital database of the geologic map of the island of Hawai' $i$ : U.S. Geological Survey Data Series 144, supplement to Miscellaneous Investigations Series Map I-2524-A, 18 p., 1 sheet, scale 1:100,000.

Wolfe, E.W., and Morris, J., 1996, Geologic map of the island of Hawaii: U.S. Geological Survey Miscellaneous Investigations Series Map I-2524-A, 18 p., 3 sheets, scale 1:100,000. 


\section{0a, Northwest Volcanic Lineament, Kohala Volcano}

\section{Section number 2600a.}

Section name Northwest volcanic lineament.

Comments: Informal name chosen by the senior author, based on Peterson and Moore (1987).

Class of structure Not applicable.

Comments: None.

State Hawaii.

County Hawaii.

$\mathbf{1}^{\circ} \mathbf{x} \mathbf{2}^{\circ}$ sheet Hawaii, HI, 1:250,000 scale, 1975.

Comments: Located on the Hāwī, Kamuela, and Kawaihae 7.5-minute topographic sheets.

\section{Reliability of location Poor.}

Comments: The northwest volcanic lineament may follow a preexisting, shield-stage rift zone structure (Wolfe and Morris, 1996). Peterson and Moore (fig. 7.2, 1987) use the term "rift zone" in place of "volcanic lineament" and show the general trend of a northwest rift zone on a regional-scale map of Hawai 'i. Holcomb and others (2000) offer alternative rift zone models (fig. 2).

Digital trace Inferred based on the locations of Kohala scoria cones and lava domes shown on the 1:100,000-scale geologic map from Wolfe and Morris (1996), available in digital format from Trusdell and others (2006), generalized for this compilation.

Average strike (azimuth) N. $39^{\circ}$ W. $\pm 11^{\circ} ;-39^{\circ} \pm 11^{\circ}$.

Length $(\mathrm{km}) 24.7$ (end to end); 25.0 (cumulative).

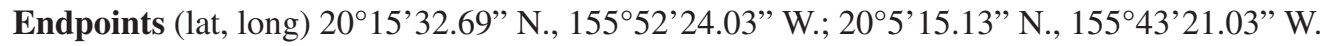

Sense of movement Presumably extension that produces normal faulting.

Dip Presumably near vertical to vertical.

Dip direction Presumably NE, SW.

Geomorphic expression A broad topographic ridge trends northwest from the summit region of the Kohala Mountains and continues northward offshore as a broad submarine ridge. The locations of Pleistocene shield-stage to transitional Pololū and postshield-stage Hāwī scoria cones and lava domes are generally located along this broad topographic ridge. Note that Wolfe and Morris (1996) only associate rift zones with the shield-stage phase of volcanism, which ended on Kohala about $400 \mathrm{ka}$.

Age of faulted deposits Wolfe and Morris (1996) summarize the K-Ar ages from several researchers for the postshield-stage Hāwī Volcanics as being between $230 \mathrm{ka}$ and $120 \mathrm{ka}$. Dalrymple (1971) calculates $700 \mathrm{ka}$ for the weighted mean age of five tholeiitic shield-stage Pololū lava flows located in Waipi`o Valley. Wolfe and Morris (1996) redefine the Pololū Volcanics as shield-stage to transitional.

Timing of most recent paleoevent Middle to Late Quaternary $(<750 \mathrm{ka})$.

Comments: An active rift zone located along the general trend of the northwest volcanic lineament probably occurred during shield-stage volcanism about $700 \mathrm{ka}$ to $400 \mathrm{ka}$. Once the volcano reached postshield stage, volcanic activity along the rift zone probably declined greatly (Wolfe and Morris, 1996), and postshield stage of volcanism buried the inactive, shield-stage rift zone. Postshield-stage Hāwī scoria cones and lava domes crop out along the northwest volcanic lineament indicating that some magma transport may have followed rift zone pathways during postshield-stage volcanism. 
Recurrence interval Not reported.

Slip rate Unknown; probably $<0.2 \mathrm{~mm} / \mathrm{yr}$ and likely inactive.

Comments: Herein considered to be $<0.2 \mathrm{~mm} / \mathrm{yr}$ and likely inactive. Postshield-stage eruptive activity at Kohala has ceased (Wolfe and Morris, 1996).

\section{References}

Dalrymple, G.B., 1971, Potassium-argon ages from the Pololu volcanic series, Kohala Volcano, Hawaii: Geological Society of America Bulletin, v. 82, no. 7, p. 1,997-2,000.

Holcomb, R.T., Nelson, B.K., Reiners, P.W., and Sawyer, N.-L., 2000, Overlapping volcanoes—The origin of Hilo Ridge, Hawaii: Geology, v. 28, no. 6, p. 547-550.

Peterson, D.W., and Moore, R.B., 1987, Geologic history and evolution of geologic concepts, Island of Hawaii, in Decker, R.W.,Wright, T.L., and Stauffer, P.H., eds., Volcanism in Hawaii: U.S. Geological Survey Professional Paper 1350, v. 1, p. 149-189.

Trusdell, F.A., Wolfe, E.W., and Morris, J., 2006, Digital database of the geologic map of the island of Hawai'i: U.S. Geological Survey Data Series 144, supplement to Miscellaneous Investigations Series Map I-2524-A, 18 p., 1 sheet, scale 1:100,000.

Wolfe, E.W., and Morris, J., 1996, Geologic map of the island of Hawaii: U.S. Geological Survey Miscellaneous Investigations Series Map I-2524-A, 18 p., 3 sheets, scale 1:100,000.

\section{0b, Southeast Volcanic Lineament, Kohala Volcano}

Section number $2600 b$.

Section name Southeast volcanic lineament. Comments: Informal name chosen by the senior author, based on Peterson and Moore (1987).

Class of structure Not applicable.

Comments: None.

State Hawaii.

County Hawaii.

$\mathbf{1}^{\circ} \mathbf{x}{ }^{\circ}$ sheet Hawaii, HI, 1:250,000 scale, 1975.

Comments: Located on the Kamuela 7.5-minute sheet.

\section{Reliability of location Poor.}

Comments: The southeast volcanic lineament may follow a preexisting, shield-stage rift zone structure (Wolfe and Morris, 1996). Peterson and Moore (fig. 7.2, 1987) use the term "rift zone" in place of "volcanic lineament" and show the general trend of a southeast rift zone on a regional scale map of Hawai'i. Holcomb and others (2000) offer alternative rift zone models (fig. 2), including one showing Kohala's southeast rift zone as extending to the Hilo Ridge and not the Hilo Ridge as a rift zone of Mauna Kea.

Digital trace Inferred based on the locations of Kohala scoria cones and lava domes shown on the 1:100,000-scale geologic map from Wolfe and Morris (1996), available in digital format from Trusdell and others (2006), generalized for this compilation.

Average strike (azimuth) N. $59^{\circ}$ W. $\pm 4^{\circ} ;-59^{\circ} \pm 4^{\circ}$.

Length (km) 10.9 (end to end); 10.9 (cumulative).

Endpoints (lat, long) 205'15.13” N., 15543’21.03” W.; 20²’19.49” N., $155^{\circ} 37$ 53.40” W.

Sense of movement Presumably extension that produces normal faulting. 
Dip Presumably near vertical to vertical.

Dip direction Presumably NE, SW.

Geomorphic expression A poorly defined, broad topographic ridge trends southeast from the summit region of the Kohala Mountains. The locations of Pleistocene shield-stage to transitional Pololū and postshield-stage Hāwī scoria cones and lava domes are generally located along this broad topographic ridge. Note that Wolfe and Morris (1996) only associate rift zones with the shield-stage phase of volcanism, which ended on Kohala about $400 \mathrm{ka}$.

Age of faulted deposits Wolfe and Morris (1996) summarize the K-Ar ages from several researchers for the postshield-stage Hāwī Volcanics as being between $230 \mathrm{ka}$ and $120 \mathrm{ka}$. Dalrymple (1971) calculates $700 \mathrm{ka}$ for the weighted mean age of five tholeiitic shield-stage Pololū lava flows in Waipi ‘o Valley. Wolfe and Morris (1996) redefine the Pololū Volcanics as shieldstage to transitional.

Timing of most recent paleoevent Middle to late Quaternary ( $<750 \mathrm{ka})$.

Comments: An active rift zone located along the general trend of the southeast volcanic lineament probably occurred during shield-stage volcanism about $700 \mathrm{ka}$ to $400 \mathrm{ka}$. Once the volcano reached postshield-stage, volcanic activity along the rift zone probably declined greatly (Wolfe and Morris, 1996), and postshield-stage volcanism buried the inactive, shield-stage rift zone. Postshield-stage Hāwī scoria cones and lava domes crop out along the southeast volcanic lineament indicating that some magma transport may have followed rift zone pathways during postshield-stage volcanism.

\section{Recurrence interval Not reported.}

Slip rate Unknown; probably $<0.2 \mathrm{~mm} / \mathrm{yr}$ and likely inactive.

Comments: Herein considered to be $<0.2 \mathrm{~mm} / \mathrm{yr}$ and likely inactive. Postshield-stage eruptive activity at Kohala has ceased (Wolfe and Morris, 1996).

\section{References}

Dalrymple, G.B., 1971, Potassium-argon ages from the Pololu volcanic series, Kohala Volcano, Hawaii: Geological Society of America Bulletin, v. 82, no. 7, p. 1,997-2,000.

Holcomb, R.T., Nelson, B.K., Reiners, P.W., and Sawyer, N.-L., 2000, Overlapping volcanoes-The origin of Hilo Ridge, Hawaii: Geology, v. 28, no. 6, p. 547-550.

Peterson, D.W., and Moore, R.B., 1987, Geologic history and evolution of geologic concepts, Island of Hawaii, in Decker, R.W., Wright, T.L., and Stauffer, P.H., eds., Volcanism in Hawaii: U.S. Geological Survey Professional Paper 1350, v. 1, p. 149-189.

Trusdell, F.A., Wolfe, E.W., and Morris, J., 2006, Digital database of the geologic map of the island of Hawai 'i: U.S. Geological Survey Data Series 144, supplement to Miscellaneous Investigations Series Map I-2524-A, 18 p., 1 sheet, scale 1:100,000.

Wolfe, E.W., and Morris, J., 1996, Geologic map of the island of Hawaii: U.S. Geological Survey Miscellaneous Investigations Series Map I-2524-A, 18 p., 3 sheets, scale 1:100,000.

\section{0c, Kohala Graben Section, Kohala Volcano}

Section number 2600c.

Section name Kohala graben.

Comments: Informal name chosen by the senior author, based on Moore and others (1989).

Class of structure Not applicable.

Comments: None.

State Hawaii.

County Hawaii. 
$\mathbf{1}^{\circ} \mathbf{x} \mathbf{2}^{\circ}$ sheet Hawaii, HI, 1:250,000 scale, 1975.

Comments: Located on the Honokāne and Kamuela 7.5-minute sheets.

\section{Reliability of location Good.}

Comments: The 32 normal fault traces that compose the Kohala graben are shown on Sheet 1 of 3 of Wolfe and Morris (1996).

Digital trace From the 1:100,000-scale geologic map compiled by Wolfe and Morris (1996), available in digital format from Trusdell and others (2006), generalized for this compilation.

Average strike (azimuth) N. $54^{\circ}$ W. $\pm 28^{\circ} ;-54^{\circ} \pm 28^{\circ}$.

Length $(\mathrm{km}) 15.4$ (end to end); 57.8 (cumulative).

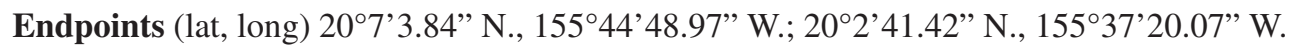

\section{Sense of movement Normal.}

Comments: From Wolfe and Morris (1996).

Dip Not reported.

Dip direction SW or NE.

Comments: Generally southwest or northeast as shown by Wolfe and Morris (1996).

Geomorphic expression The Kohala graben is composed of a series of normal faults that form a broad zone trending roughly N. $60^{\circ} \mathrm{W}$. Moore and others (1989) interpret the normal faults to represent a pull-apart graben at the head of a visible subaerial landslide amphitheater, which continues offshore as the submarine Pololū debris avalanche (fig. 1) (see section [2600d], Kohala headwall).

Age of faulted deposits The faults of the Kohala graben cut middle to late Pleistocene Hāwī lava flows and domes, scoria cones, and Pololū lava flows. Wolfe and Morris (1996) summarize the K-Ar ages from several researchers for the postshield-stage Hāwī Volcanics as being between $230 \mathrm{ka}$ and $120 \mathrm{ka}$. Dalrymple (1971) calculates $700 \mathrm{ka}$ as the weighted mean age of five tholeiitic shield-stage Pololū lava flows in Waipi ‘o Valley. Wolfe and Morris (1996) redefine the Pololū Volcanics as shield-stage to transitional.

Timing of most recent paleoevent Middle to late Quaternary ( $<750 \mathrm{ka})$.

Comments: Moore and others (1989) estimate the age of the Pololū debris avalanche to be "slightly older" than 370 ka. Their estimate is based on bathymetry that suggests the debris avalanche material shows a slope change attributed to the transition from shield-stage to postshield-stage volcanism dated at $370 \mathrm{ka}$ from subsidence rates and modeled coral reef ages. Surface faults cut through both shield-stage Pololū Volcanics and postshield-stage 230 ka to 120 ka Hāwī Volcanics (Wolfe and Morris, 1996).

\section{Recurrence interval Not reported.}

Slip rate Unknown; probably $<0.2 \mathrm{~mm} / \mathrm{yr}$ and likely inactive.

Comments: Herein considered to be $<0.2 \mathrm{~mm} / \mathrm{yr}$ and likely inactive. The Pololū debris avalanche may represent a one-time, catastrophic event, perhaps triggered by an earthquake. If so, then the Kohala graben, interpreted by Moore and others (1989) as a pull-apart graben at the head of the Pololū debris avalanche, may be inactive at present. Additionally, postshield-stage eruptive activity at Kohala has ceased (Wolfe and Morris, 1996).

\section{References}

Dalrymple, G.B., 1971, Potassium-argon ages from the Pololu volcanic series, Kohala Volcano, Hawaii: Geological Society of America Bulletin, v. 82, no. 7, p. 1,997-2,000.

Moore, J.G., Clague, D.A., Holcomb, R.T., Lipman, P.W., Normark, W.R., and Torresan, M.E., 1989, Prodigious submarine landslides on the Hawaiian Ridge: Journal of Geophysical Research, v. 94, no. B12, p. 17,465-17,484. 
Trusdell, F.A., Wolfe, E.W., and Morris, J., 2006, Digital database of the geologic map of the island of Hawai 'i: U.S. Geological Survey Data Series 144, supplement to Miscellaneous Investigations Series Map I-2524-A, 18 p., 1 sheet, scale 1:100,000.

Wolfe, E.W., and Morris, J., 1996, Geologic map of the island of Hawaii: U.S. Geological Survey Miscellaneous Investigations Series Map I-2524-A, 18 p., 3 sheets, scale 1:100,000.

\section{0d, Kohala Headwall Section, Kohala Volcano}

\section{Section number 2600d.}

Section name Kohala headwall.

Comments: Informal name chosen by the senior author, based on Moore and others (1989).

Class of structure Not applicable.

Comments: None.

State Hawaii.

County Hawaii.

$\mathbf{1}^{\circ} \mathbf{x} 2^{\circ}$ sheet Hawaii, HI, 1:250,000 scale, 1975.

Comments: Located on the Honokāne and Kukuihaele 7.5-minute topographic sheets.

\section{Reliability of location Good.}

Comments: Inferred from the reentrant coastline, an embayment shown on the 1:100,000-scale geologic map compiled by Wolfe and Morris (1996), based on information from Moore and others (1989).

Digital trace Inferred from the reentrant coastline shown on the 1:100,000-scale geologic map compiled by Wolfe and Morris (1996), available in digital format from Trusdell and others (2006).

Average strike (azimuth) N. $63^{\circ} \mathrm{W} . \pm 24^{\circ} ;-63^{\circ} \pm 24^{\circ}$.

Length $(\mathrm{km}) 20.5$ (end to end); 22.2 (cumulative).

Comments: Wolfe and Morris (1996) define the headwall as the embayment from Akoakoa Point to Kukuihaela, northwest to southeast, respectively. For this compilation, the southeast end of the headwall is considered to be Kukuihaele Landing located along the coast approximately $1 \mathrm{~km}$ from the town of Kukuihaele.

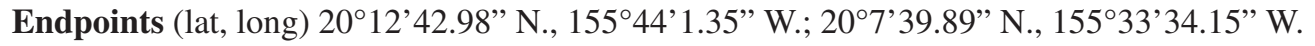

Sense of movement Normal.

Comments: From Moore and others (1989).

Dip Not reported.

Dip direction NE.

Comments: From Moore and others (1989).

Geomorphic expression The sea cliffs that form the Kohala headwall have as much as $400 \mathrm{~m}$ of topographic relief and form a 20-km-long reentrant in the coastline that extends the shoreline inland about $2 \mathrm{~km}$ (Moore and others, 1989). Access to the sea cliffs is extremely difficult due to heavy vegetation and steep slopes. At Waipi 'o Bay, $4 \mathrm{~km}$ west of Kukuihaele Landing, there is no visible surface trace of an active fault. Moore and others (1989) interpret the reentrant coastline along the coast from Kukuihaele to Akoakoa Point as the headwall of the submarine Pololū debris avalanche that has been modified by erosion (fig. 1).

Age of faulted deposits The sea cliffs are composed of middle Pleistocene Pololū lava flows (Wolfe and Morris, 1996). Dalrymple (1971) calculates 700 ka for the weighted mean age of five tholeiitic shield-stage Pololū lava flows located in Waipi`o Valley. Wolfe and Morris (1996) redefine the Pololū Volcanics as shield-stage to transitional. 
Timing of most recent paleoevent Middle to Late Quaternary ( $<750 \mathrm{ka})$.

Comments: Moore and others (1989) estimate the age of the Pololū debris avalanche to be "slightly older" than 370 ka. Their estimate is based on bathymetry that suggests the debris avalanche material shows a slope change attributed to the transition from shield-stage to postshield-stage volcanism dated at $370 \mathrm{ka}$ from subsidence rates and modeled coral-reef ages.

Recurrence interval Not reported.

Slip rate Unknown; probably $<0.2 \mathrm{~mm} / \mathrm{yr}$ and likely inactive.

Comments: Herein considered to be $<0.2 \mathrm{~mm} / \mathrm{yr}$ and likely inactive. The Pololū debris avalanche may represent a one-time, catastrophic event, perhaps triggered by an earthquake. If so, then the Kohala headwall may be inactive at present. Additionally, postshield-stage eruptive activity at Kohala has ceased (Wolfe and Morris, 1996).

\section{References}

Dalrymple, G.B., 1971, Potassium-argon ages from the Pololu volcanic series, Kohala Volcano, Hawaii: Geological Society of America Bulletin, v. 82, no. 7, p. 1,997-2,000.

Moore, J.G., Clague, D.A., Holcomb, R.T., Lipman, P.W., Normark, W.R., and Torresan, M.E., 1989, Prodigious submarine landslides on the Hawaiian Ridge: Journal of Geophysical Research, v. 94, no. B12, p. 17,465-17,484.

Trusdell, F.A., Wolfe, E.W., and Morris, J., 2006, Digital database of the geologic map of the island of Hawai 'i: U.S. Geological Survey Data Series 144, supplement to Miscellaneous Investigations Series Map I-2524-A, 18 p., 1 sheet, scale 1:100,000.

Wolfe, E.W., and Morris, J., 1996, Geologic map of the island of Hawaii: U.S. Geological Survey Miscellaneous Investigations Series Map I-2524-A, 18 p., 3 sheets, scale 1:100,000.

\section{1, Mauna Kea Volcano}

Structure number 2601.

Comments: See figure 1 for map of Mauna Kea Volcano located in the northern part of the Island of Hawai $i$.

Structure name Mauna Kea Volcano.

Comments: Mauna Kea Volcano is located on Sheets 1 and 2 of 3 of the 1:100,000-scale geologic map compiled by Wolfe and Morris (1996), available in digital format from Trusdell and others (2006).

Class of structure Not applicable.

Comments: None.

Synopsis Mauna Kea Volcano is a postshield-stage volcano that last erupted approximately 4,000 years ago (Wolfe and others, 1997). Whereas Kohala [2600] and Hualālai [2602] have volcanic lineaments defined by broad topographic ridges with volcanic cones and lava flows, volcanic lineaments on Mauna Kea are very poorly developed or may not exist at present.

Date of compilation September 16, 2006.

Compiler and affiliation Eric C. Cannon; Roland Bürgmann, University of California Berkeley.

Province Hawaiian-Emperor island-seamount chain.

Geologic setting The three main surficial volcanic units found on Mauna Kea Volcano are the younger (4-13 ka) and older (16-65 ka) members of the Holocene and Pleistocene Laupāhoehoe Volcanics, and the Pleistocene Hāmākua Volcanics (65-70 ka to 200-250 ka) (Wolfe and others, 1997). Mauna Kea is the only Hawaiian volcano with documented evidence of glaciation (Porter, 1987). The three glacial members are the Pleistocene Mākanaka Glacial Member (13-40 ka), Waihū Glacial Member (70-150 ka from K-Ar dating, exposure age of 60-70 ka), and the Pōhakuloa Glacial Member (exposure age of 140-156 ka) (Porter, 1987; Wolfe and others, 1997).

\section{State Hawaii.}


County Hawaii.

$\mathbf{1}^{\circ} \mathbf{x} \mathbf{2}^{\circ}$ sheet Hawaii, HI, 1:250,000 scale, 1975.

\section{Reliability of location Poor.}

Comments: Mauna Kea does not have well-defined alignments of volcanic cones on topographic ridges to suggest that shield stage rift zones are overlain by postshield-stage volcanic lineaments. Thus, information is not provided in this compilation for the digital trace, average strike, length, endpoint locations, sense of movement, dip, or dip direction of Quaternary faults.

Refer to Peterson and Moore (1987), Wolfe and others (1997), and Holcomb and others (2000) for more details regarding their interpretation of Mauna Kea rift zones (fig. 2), including one showing Kohala's southeast rift zone as extending to the Hilo Ridge, and not the Hilo Ridge as a rift zone of Mauna Kea [2600b].

Digital trace Not provided; see plate 1 for location of Mauna Kea summit.

Average strike (azimuth) Not applicable.

Length $(\mathrm{km})$ Not applicable.

Endpoints (lat, long) Not applicable.

Sense of movement Not applicable.

Dip Not applicable.

Dip Direction Not applicable.

Geomorphic expression As discussed above, Mauna Kea does not display volcanic lineaments in the form of topographic ridges with volcanic cones. Multiple interpretations exist of the geometries of rifts associated with the volcano (fig. 2).

Age of faulted deposits The oldest surficial rocks on Mauna Kea, the Pleistocene Hāmākua Volcanics (65-70 ka to 200-250 ka; Wolfe and others, 1997), are not faulted.

Timing of most recent paleoevent Quaternary $(<1.6 \mathrm{Ma})$.

Comments: Multiple rift zones probably existed on Mauna Kea during active shield-stage volcanism. Mauna Kea's volcanism started approximately $1 \mathrm{Ma}$, and the transition from shield-stage to postshield-stage volcanism took place approximately 200-250 ka (Wolfe and others, 1997). Once the volcano reached postshield-stage, volcanic activity along the rift zones probably declined greatly (Wolfe and Morris, 1996), and postshield-stage volcanism buried the inactive, shield-stage rift zones. Postshield-stage Laupāhoehoe and Hāmākua Volcanics scoria cones and lava domes crop out on Mauna Kea, and magma transport may or may not have followed rift zone pathways during postshield-stage volcanism.

Recurrence interval Not reported.

Slip rate Unknown; probably $<0.2 \mathrm{~mm} / \mathrm{yr}$ and likely inactive.

Comments: Herein considered to be $<0.2 \mathrm{~mm} / \mathrm{yr}$ and likely inactive. The most recent postshield-stage eruptive activity on Mauna Kea occurred approximately 4,000 years ago (Wolfe and others, 1997).

\section{References}

Holcomb, R.T., Nelson, B.K., Reiners, P.W., and Sawyer, N.-L., 2000, Overlapping volcanoes-The origin of Hilo Ridge, Hawaii: Geology, v. 28, no. 6, p. 547-550.

Peterson, D.W., and Moore, R.B., 1987, Geologic history and evolution of geologic concepts, Island of Hawaii, in

Decker, R.W., Wright, T.L., and Stauffer, P.H., eds., Volcanism in Hawaii: U.S. Geological Survey Professional Paper 1350, v. 1, p. 149-189.

Porter, S.C., 1987, Pleistocene subglacial eruptions on Mauna Kea, in Decker, R.W., Wright, T.L., and Stauffer, P.H., eds., Volcanism in Hawaii: U.S. Geological Survey Professional Paper 1350, v. 1, p. 587-598. 
Trusdell, F.A., Wolfe, E.W., and Morris, J., 2006, Digital database of the geologic map of the island of Hawai'i: U.S. Geological Survey Data Series 144, supplement to Miscellaneous Investigations Series Map I-2524-A, 18 p., 1 sheet, scale 1:100,000.

Wolfe, E.W., and Morris, J., 1996, Geologic map of the island of Hawaii: U.S. Geological Survey Miscellaneous Investigations Series Map I-2524-A, 18 p., 3 sheets, scale 1:100,000.

Wolfe, E.W., Wise, W.S., and Dalrymple, G.B., 1997, The geology and petrology of Mauna Kea Volcano, Hawaii; a study of postshield volcanism: U.S. Geological Survey Professional Paper 1557, 129 p., 4 pls., scale 1:24,000 and 1:100,000.

\section{2, Hualālai Volcano}

Structure number 2602.

Comments: See figure 1 for the location map of Hualālai Volcano located in the western part of the Island of Hawai'i.

Structure name Hualālai Volcano.

Comments: Hualālai Volcano is located on Sheet 1 of 3 of the 1:100,000-scale geologic map compiled by Wolfe and Morris (1996), available in digital format from Trusdell and others (2006). Wolfe and Morris (1996) use the 1:50,000-scale geologic map of Hualālai from Moore and Clague (1991).

Synopsis Hualālai Volcano, the oldest of the three active volcanoes on Hawai ${ }^{i} i$, has three poorly defined volcanic lineaments inferred along broad topographic ridges, the northwest [2602a], north [2602b], and south-southeast [2602c] volcanic lineaments. Other researchers, including Moore and others (1987) and Kauahikaua and others (2002), use the term "rift zone" in place of "volcanic lineament." The rift zones in Moore and others (1987) appear to radiate from a central point approximately $5 \mathrm{~km}$ east of the summit of Hāinoa Crater. Holcomb and others (2000) offer alternative rift zone models (fig. 2). Offshore, the North Kona slump is located on the western flanks of Hualālai and Mauna Loa Volcanoes (fig. 1) (Moore and Chadwick, 1995). The landslide head may correspond with the northwest rift zone on Hualālai (Moore and Chadwick, 1995).

Date of compilation September 16, 2006.

Compiler and affiliation Eric C. Cannon; Roland Bürgmann, University of California Berkeley.

Province Hawaiian-Emperor island-seamount chain.

Geologic setting The surface of postshield-stage Hualālai consists of transitional to postshield-stage Holocene and Pleistocene Hualālai Volcanics, and the Pleistocene Wa 'awa'a Trachyte Member (Moore and Clague, 1991; Wolfe and Morris, 1996). The transition from shield- to postshield-stage volcanism occurred between $130 \mathrm{ka}$ and $105 \mathrm{ka}$ (Wolfe and Morris, 1996). The most recent eruption occurred along the northwest rift zone in 1800-1801 (Clague and Dalrymple, 1987; Moore and others, 1987; Kauahikaua and others, 2002). Based on records of increased seismicity, Moore and others (1987) speculate that an intrusion occurred in 1929. Future eruptions may have short periods of precursory seismic activity (Moore and others, 1987), although there is concern for the possibility of a rapid rise of magma without much seismic activity (D.A. Swanson, written commun., 2005).

Number of sections 3.

Comments: The three sections are the northwest [2602a], north [2602b], and south-southeast [2602c] volcanic lineaments.

Average strike (azimuth) N. $32^{\circ} \mathrm{W} . \pm 22^{\circ} ;-32^{\circ} \pm 22^{\circ}$.

Length $(\mathrm{km}) 35.5$ (end to end); 49.1 (cumulative).

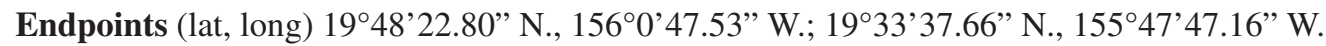

\section{References}

Clague, D.A., and Dalrymple, G.B., 1987, The Hawaiian-Emperor volcanic chain. Part I. Geologic evolution, in Decker, R.W., Wright, T.L., and Stauffer, P.H., eds., Volcanism in Hawaii: U.S. Geological Survey Professional Paper 1350, v. 1, p. $5-54$. 
Holcomb, R.T., Nelson, B.K., Reiners, P.W., and Sawyer, N.-L., 2000, Overlapping volcanoes-The origin of Hilo Ridge, Hawaii: Geology, v. 28, no. 6, p. 547-550.

Kauahikaua, J., Cashman, K.V., Clague, D.A., Champion, D., and Hagstrum, J.T., 2002, Emplacement of the most recent lava flows on Hualalai Volcano, Hawai'i: Bulletin of Volcanology, v. 64, p. 229-253.

Moore, J.G., and Chadwick, W.W., Jr., 1995, Offshore geology of Mauna Loa and adjacent areas, Hawaii, in Rhodes, J.M., and Lockwood, J.P., eds., Mauna Loa revealed—Structure, composition, history, and hazards: American Geophysical Union Geophysical Monograph, v. 92, p. 21-44.

Moore, R.B., and Clague, D.A., 1991, Geologic map of Hualalai Volcano, Hawaii: U.S. Geological Survey Miscellaneous Investigations Series Map I-2213, scale 1:50,000.

Moore, R.B., Clague, D.A., Rubin, M., and Bohrson, W.A., 1987, Hualalai Volcano-A preliminary summary of geologic, petrologic, and geophysical data, in Decker, R.W., Wright, T.L., and Stauffer, P.H., eds., Volcanism in Hawaii: U.S. Geological Survey Professional Paper 1350, v. 1, p. 571-585.

Trusdell, F.A., Wolfe, E.W., and Morris, J., 2006, Digital database of the geologic map of the island of Hawai'i: U.S. Geological Survey Data Series 144, supplement to Miscellaneous Investigations Series Map I-2524-A, 18 p., 1 sheet, scale 1:100,000.

Wolfe, E.W., and Morris, J., 1996, Geologic map of the island of Hawaii: U.S. Geological Survey Miscellaneous Investigations Series Map I-2524-A, 18 p., 3 sheets, scale 1:100,000.

\section{2a, Northwest Volcanic Lineament, Hualālai Volcano}

\section{Section number 2602a.}

Section name Northwest volcanic lineament.

Comments: Informal name chosen by the senior author, based on Moore and others (1987).

Class of structure Not applicable.

Comments: None.

State Hawaii.

County Hawaii.

$\mathbf{1}^{\circ} \mathbf{x} \mathbf{2}^{\circ}$ sheet Hawaii, HI, 1:250,000 scale, 1975.

Comments: Located on the Hualālai, Kailua, Kīholo, and Makalawena 7.5-minute topographic sheets.

\section{Reliability of location Poor.}

Comments: The northwest volcanic lineament may follow a preexisting, shield-stage rift zone structure (Wolfe and Morris, 1996). Peterson and Moore (fig. 7.2, 1987) show the general trend of the northwest rift zone on a regional-scale map of Hawai 'i. Holcomb and others (2000) offer alternative rift zone models (fig. 2). Moore and others (1987) present an aerial photograph of the northwest rift zone.

Digital trace Inferred based on the locations of Hualālai Volcanics spatter cones, scoria cones, and lava flows, in addition to the topographic ridge crest shown on the 1:100,000-scale geologic map compiled by Wolfe and Morris (1996), available in digital format from Trusdell and others (2006), generalized for this compilation.

Average strike (azimuth) N. $55^{\circ} \mathrm{W} . \pm 14^{\circ} ;-55^{\circ} \pm 14^{\circ}$.

Length $(\mathrm{km}) 24.2$ (end to end); 24.8 (cumulative).

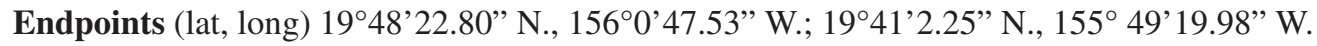

Sense of movement Presumably extension that produces normal faulting.

Dip Presumably near vertical to vertical.

Dip direction Presumably NE, SW. 
Geomorphic expression A broad topographic ridge trends northwest on Hualālai with lava flow paths initiating at the ridge crest and continuing down opposite sides of the ridge. Hualālai Volcanics spatter and scoria cones crop out along the broad topographic ridge. The northwest rift zone, described as "prominent" with numerous volcanic vents, is $2-4 \mathrm{~km}$ wide and $24 \mathrm{~km}$ long on land (Moore and others, 1987). During the 1800-1801 eruption, lava flowed from vents on the northwest rift zone (Moore and others, 1987; Kauahikaua and others, 2002). Offshore, the rift zone may extend an additional $70 \mathrm{~km}$ to the northwest as a submarine ridge (Fornari, 1987; Moore and others, 1987; Moore and Chadwick, 1995). Moore and Chadwick (1995) suggest that to the west, the landslide head from the offshore North Kona slump may be in the vicinity of the northwest rift zone axis (fig. 1).

Age of faulted deposits From Wolfe and Morris (1996), the ages of Hualālai Volcanics scoria and spatter cones that define the volcanic lineament range in age from $0.0-0.2 \mathrm{ka}$ to $>10.0 \mathrm{ka}$. The oldest Hualālai Volcanics basalt flow is $\geq 13 \mathrm{ka}$ (Wolfe and Morris, 1996). See Moore and others (1987) for a detailed list of dated samples from Hualālai.

Timing of most recent paleoevent Middle to Late Quaternary ( $<750 \mathrm{ka})$.

Comments: The transition from shield- to postshield-stage volcanism occurred between $130 \mathrm{ka}$ and $105 \mathrm{ka}$ for Hualālai (Wolfe and Morris, 1996). Once the volcano reached the postshield-stage, volcanic activity along the northwest rift zone probably declined greatly and postshield-stage volcanism buried the inactive, shield-stage rift zone. Moore and Chadwick (1995) comment that the main North Kona slump movement probably occurred prior to $130 \mathrm{ka}$ during shield-stage volcanism. The Holocene and latest Pleistocene $(<15 \mathrm{ka})$ volcanic rocks along the northwest volcanic lineament today indicate that some magma transport may have followed old rift zone pathways to the surface. Some fracturing may have occurred to produce fissures during the 1800-1801 eruption.

\section{Recurrence interval Not reported.}

Slip rate Unknown; probably $<0.2 \mathrm{~mm} / \mathrm{yr}$ and likely inactive.

Comments: Not reported by Moore and others (1987). Herein considered to be $<0.2 \mathrm{~mm} / \mathrm{yr}$ and likely inactive. Although eruptions have occurred as recently as 1800-1801 and in the Holocene, the volcano transitioned into postshield-stage volcanism between $130 \mathrm{ka}$ and $105 \mathrm{ka}$ (Wolfe and Morris, 1996), suggesting that the shield-stage rift zones are inactive at present.

\section{References}

Fornari, D.J., 1987, The geomorphic and structural development of Hawaiian submarine rift zones, in Decker, R.W., Wright, T.L., and Stauffer, P.H., eds., Volcanism in Hawaii: U.S. Geological Survey Professional Paper 1350, v. 1, p. 125-132.

Holcomb, R.T., Nelson, B.K., Reiners, P.W., and Sawyer, N.-L., 2000, Overlapping volcanoes-The origin of Hilo Ridge, Hawaii: Geology, v. 28, no. 6, p. 547-550.

Kauahikaua, J., Cashman, K.V., Clague, D.A., Champion, D., and Hagstrum, J.T., 2002, Emplacement of the most recent lava flows on Hualalai Volcano, Hawai 'i: Bulletin of Volcanology, v. 64, p. 229-253.

Moore, J.G., and Chadwick, W.W., Jr., 1995, Offshore geology of Mauna Loa and adjacent areas, Hawaii, in Rhodes, J.M., and Lockwood, J.P., eds., Mauna Loa revealed-Structure, composition, history, and hazards: American Geophysical Union Geophysical Monograph, v. 92, p. 21-44.

Moore, R.B., Clague, D.A., Rubin, M., and Bohrson, W.A., 1987, Hualalai Volcano-A preliminary summary of geologic, petrologic, and geophysical data, in Decker, R.W., Wright, T.L., and Stauffer, P.H., eds., Volcanism in Hawaii: U.S. Geological Survey Professional Paper 1350, v. 1, p. 571-585.

Peterson, D.W., and Moore, R.B., 1987, Geologic history and evolution of geologic concepts, Island of Hawaii, in Decker, R.W., Wright, T.L., and Stauffer, P.H., eds., Volcanism in Hawaii: U.S. Geological Survey Professional Paper 1350, v. 1, p. 149-189.

Trusdell, F.A., Wolfe, E.W., and Morris, J., 2006, Digital database of the geologic map of the island of Hawai'i: U.S. Geological Survey Data Series 144, supplement to Miscellaneous Investigations Series Map I-2524-A, 18 p., 1 sheet, scale $1: 100,000$.

Wolfe, E.W., and Morris, J., 1996, Geologic map of the island of Hawaii: U.S. Geological Survey Miscellaneous Investigations Series Map I-2524-A, 18 p., 3 sheets, scale 1:100,000.

\section{2b, North Volcanic Lineament, Hualālai Volcano}

Section number $2602 b$. 
Section name North volcanic lineament.

Comments: Informal name chosen by the senior author, based on Moore and others (1987).

Class of structure Not applicable.

Comments: None.

State Hawaii.

County Hawaii.

$\mathbf{1}^{\circ} \mathbf{x} \mathbf{2}^{\circ}$ sheet Hawaii, HI, 1:250,000 scale, 1975.

Comments: Located on the Hualālai and $\mathrm{Pu}$ 'u Anahulu 7.5-minute topographic sheets.

Reliability of location Poor.

Comments: The north volcanic lineament may follow a preexisting, shield-stage rift zone structure. Peterson and Moore (fig. 7.2, 1987) show the general trend of the north rift zone in a regional-scale map of Hawai 'i. Holcomb and others (2000) offer alternative rift zone models (fig. 2). Moore and others (1987) present an aerial photograph of the north rift zone.

Digital trace Inferred based on the locations of Hualālai Volcanics spatter cones, scoria cones, and lava flows, and the Pu'u Wa'awa'a Trachyte scoria cone shown on the 1:100,000-scale geologic map compiled by Wolfe and Morris (1996), available in digital format from Trusdell and others (2006), generalized for this compilation.

Average strike (azimuth) N. $8^{\circ} \mathrm{W} . \pm 0^{\circ} ;-8^{\circ} \pm 0^{\circ}$.

Length $(\mathrm{km}) 10.4$ (end to end); 10.4 (cumulative).

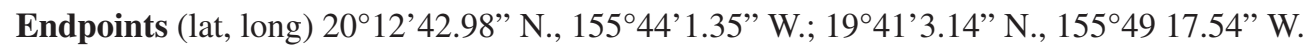

Sense of movement Presumably extension.

Dip Presumably near vertical to vertical.

Dip direction Generally E, W.

Geomorphic expression The north volcanic lineament is very weakly defined by a series of Hualālai Volcanics spatter and scoria cones and the Pu'u Wa'awa'a Trachyte scoria cone. The north rift zone does not form a topographically high ridge with respect to the volcanic edifice. Moore and others (1987) describe the north rift zone as "ill-defined" due to the decreased numbers of volcanic vents and cones. No lava flowed from the north rift zone during the 1800-1801 eruption.

Age of faulted deposits From Wolfe and Morris (1996), the ages of Hualālai Volcanics scoria and spatter cones that define the north volcanic lineament range in age from 1.5-3.0 ka to $>10.0 \mathrm{ka}$. The oldest Hualālai Volcanics basalt flow is $\geq 13 \mathrm{ka}$ (Wolfe and Morris, 1996). See Moore and others (1987) for a detailed list of dated samples from Hualālai Volcano.

Timing of most recent paleoevent Middle to Late Quaternary (<750 ka).

Comments: The transition from shield- to postshield-stage volcanism occurred between $130 \mathrm{ka}$ and $105 \mathrm{ka}$ for Hualālai (Wolfe and Morris, 1996). Once the volcano reached postshield-stage, volcanic activity along the north rift zone probably declined greatly and postshield-stage volcanism buried the inactive, shield-stage rift zone. The Holocene and latest Pleistocene $(<15 \mathrm{ka})$ volcanic rocks found along the north volcanic lineament today indicate that some magma transport may have followed old rift zone pathways to the surface.

Recurrence interval Not reported.

Slip rate Unknown; probably $<0.2 \mathrm{~mm} / \mathrm{yr}$ and likely inactive.

Comments: Not reported by Moore and others (1987). Herein considered to be $<0.2 \mathrm{~mm} / \mathrm{yr}$ and likely inactive. Although eruptions have occurred as recently as 1800-1801 and in the Holocene, the volcano transitioned into postshield-stage volcanism between $130 \mathrm{ka}$ and $105 \mathrm{ka}$ (Wolfe and Morris, 1996), suggesting that the shield-stage rift zones are inactive at present. 


\section{References}

Holcomb, R.T., Nelson, B.K., Reiners, P.W., and Sawyer, N.-L., 2000, Overlapping volcanoes-The origin of Hilo Ridge, Hawaii: Geology, v. 28, no. 6, p. 547-550.

Moore, R.B., Clague, D.A., Rubin, M., and Bohrson, W.A., 1987, Hualalai Volcano-A preliminary summary of geologic, petrologic, and geophysical data, in Decker, R.W., Wright, T.L., and Stauffer, P.H., eds., Volcanism in Hawaii: U.S. Geological Survey Professional Paper 1350, v. 1, p. 571-585.

Peterson, D.W., and Moore, R.B., 1987, Geologic history and evolution of geologic concepts, Island of Hawaii, in Decker, R.W., Wright, T.L., and Stauffer, P.H., eds., Volcanism in Hawaii: U.S. Geological Survey Professional Paper 1350, v. 1, p. 149-189.

Trusdell, F.A., Wolfe, E.W., and Morris, J., 2006, Digital database of the geologic map of the island of Hawai 'i: U.S. Geological Survey Data Series 144, supplement to Miscellaneous Investigations Series Map I-2524-A, 18 p., 1 sheet, scale 1:100,000.

Wolfe, E.W., and Morris, J., 1996, Geologic map of the island of Hawaii: U.S. Geological Survey Miscellaneous Investigations Series Map I-2524-A, 18 p., 3 sheets, scale 1:100,000.

\section{2c, South-Southeast Volcanic Lineament, Hualālai Volcano}

Section number $2602 c$.

Section name South-southeast volcanic lineament.

Comments: Informal name chosen by the senior author, based on Moore and others (1987).

Class of structure Not applicable.

Comments: None.

State Hawaii.

County Hawaii.

$\mathbf{1}^{\circ} \mathbf{x}{ }^{\circ}$ sheet Hawaii, HI, 1:250,000 scale, 1975.

Comments: Located on the Hualālai and $\mathrm{Pu}$ 'u Anahulu 7.5-minute topographic sheets.

\section{Reliability of location Poor.}

Comments: The south-southeast volcanic lineament may follow a preexisting, shield-stage rift zone structure (Wolfe and Morris, 1996). Peterson and Moore (fig. 7.2, 1987) show the general trend of the south-southeast rift zone on a regional-scale map of Hawai 'i. Holcomb and others (2000) offer alternative rift zone models (fig. 2). Moore and others (1987) present an aerial photograph of the south-southeast rift zone.

Digital trace Inferred based on the locations of Hualālai Volcanics spatter cones, scoria cones, and lava flows, in addition to the topographic ridge crest shown on the 1:100,000-scale geologic map compiled by Wolfe and Morris (1996), available in digital format from Trusdell and others (2006), generalized for this compilation.

Average strike (azimuth) N. $10^{\circ}$ W. $\pm 0^{\circ} ;-10^{\circ} \pm 0^{\circ}$.

Length (km) 13.9 (end to end); 13.9 (cumulative).

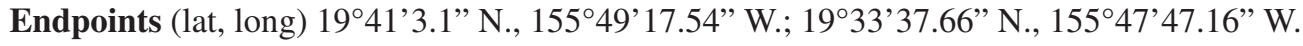

Sense of movement Presumably extension.

Dip Presumably near vertical to vertical.

Dip direction E, W. 
Geomorphic expression The south-southeast volcanic lineament is weakly defined by a series of Hualālai Volcanics spatter and scoria cones, with some lava flow paths initiating at the ridge crest and continuing down opposite sides of the ridge. The south-southeast rift zone is approximately $3-5 \mathrm{~km}$ wide and $13 \mathrm{~km}$ long (Moore and others, 1987). No lava flows occurred on the south-southeast volcanic lineament during the 1800-1801 eruption.

Age of faulted deposits From Wolfe and Morris (1996), the ages of Hualālai Volcanics scoria and spatter cones that define the south-southeast volcanic lineament range in age from $0.2-0.75 \mathrm{ka}$ to $>10.0 \mathrm{ka}$. The oldest Hualālai Volcanics basalt flow is $\geq 13 \mathrm{ka}$ (Wolfe and Morris (1996). See Moore and others (1987) for a detailed list of dated samples from Hualālai Volcano.

Timing of most recent paleoevent Middle to Late Quaternary ( $<750 \mathrm{ka})$.

Comments: The transition from shield- to postshield-stage volcanism occurred between $130 \mathrm{ka}$ and 105 ka for Hualālai (Wolfe and Morris, 1996). Once the volcano reached postshield-stage, volcanic activity along the south-southeast rift zone probably declined greatly and postshield-stage volcanism buried the inactive, shield-stage rift zone. The Holocene and latest Pleistocene ( $<15 \mathrm{ka})$ volcanic rocks found along the south-southeast volcanic lineament today indicate that some magma transport may have followed old rift zone pathways to the surface.

Recurrence interval Not reported.

Slip rate Unknown; probably $<0.2 \mathrm{~mm} / \mathrm{yr}$ and likely inactive.

Comments: Not reported by Moore and others (1987). Herein considered to be $<0.2 \mathrm{~mm} / \mathrm{yr}$ and likely inactive. Although eruptions have occurred as recently as 1800-1801 and in the Holocene, the volcano transitioned into postshield-stage volcanism between $130 \mathrm{ka}$ and $105 \mathrm{ka}$ (Wolfe and Morris, 1996), suggesting that the shield-stage rift zones are inactive at present.

\section{References}

Holcomb, R.T., Nelson, B.K., Reiners, P.W., and Sawyer, N.-L., 2000, Overlapping volcanoes-The origin of Hilo Ridge, Hawaii: Geology, v. 28, no. 6, p. 547-550.

Moore, R.B., Clague, D.A., Rubin, M., and Bohrson, W.A., 1987, Hualalai Volcano-A preliminary summary of geologic, petrologic, and geophysical data, in Decker, R.W., Wright, T.L., and Stauffer, P.H., eds., Volcanism in Hawaii: U.S. Geological Survey Professional Paper 1350, v. 1, p. 571-585.

Peterson, D.W., and Moore, R.B., 1987, Geologic history and evolution of geologic concepts, Island of Hawaii, in Decker, R.W., Wright, T.L., and Stauffer, P.H., eds., Volcanism in Hawaii: U.S. Geological Survey Professional Paper 1350, v. 1, p. 149-189.

Trusdell, F.A., Wolfe, E.W., and Morris, J., 2006, Digital database of the geologic map of the island of Hawai 'i: U.S. Geological Survey Data Series 144, supplement to Miscellaneous Investigations Series Map I-2524-A, 18 p., 1 sheet, scale 1:100,000.

Wolfe, E.W., and Morris, J., 1996, Geologic map of the island of Hawaii: U.S. Geological Survey Miscellaneous Investigations Series Map I-2524-A, 18 p., 3 sheets, scale 1:100,000.

\section{3, Kealakekua Fault System}

Structure number 2603.

Comments: See figure 1 for the location map of the Kealakekua fault system located on the west coast of the Island of Hawai' $i$.

Structure name Kealakekua fault system.

Comments: The Kealakekua fault system is located on Sheet 3 of 3 of the 1:100,000-scale geologic map compiled by Wolfe and Morris (1996).

Class of structure Not applicable.

Comments: None.

Synopsis The Kealakekua fault system may represent part of a landslide fault scarp for the numerous submarine debris avalanches and slumps off the west flank of Mauna Loa Volcano (fig. 1): 'Ālika 1 and 2 debris avalanches, South Kona debris avalanche and slump, Ka Lae East and West debris avalanches (Lipman, 1995; Moore and Chadwick, 1995; Moore and others, 1995). The Kealakekua fault system may connect with the Kahuku fault system [2604] to form the southwest Hawai'i slide complex, possibly buried beneath lava flows on the western flank of Mauna Loa (Moore and others, 1989; Lipman, 1995). 
Wolfe and Morris (1996) indicate that the subaerial traces of the Kealakekua fault system are concealed by overlying mapped volcanic units (mainly lava flows) that are $10 \mathrm{ka}$ or younger, and thus the most recent movement must be pre-Holocene.

Date of compilation September 16, 2006.

Compiler and affiliation Eric C. Cannon; Roland Bürgmann, University of California Berkeley.

Province Hawaiian-Emperor island-seamount chain.

Geologic setting The Kealakekua fault system is situated on the western flank of Mauna Loa Volcano. The fault system probably is the subaerial headwalls of massive submarine landslides (Lipman and others, 1990; Moore and others, 1995) that moved westward off the coast of Mauna Loa. The region is seismically active, with a trend in epicenter distribution associated with the fault system (Okubo, 1995). Wolfe and Morris (1996) indicate that the traces of the Kealakekua fault system are concealed by overlying mapped units 10 ka or younger.

State Hawaii.

County Hawaii.

$\mathbf{1}^{\circ} \times \mathbf{2}^{\circ}$ sheet Hawaii, HI, 1:250,000 scale, 1975.

Comments: Located on the Hōnaunau, Kauluoa Point, Kaunēnē, and Miloli ‘i 7.5-minute topographic sheets.

Reliability of location Poor.

Comments: Wolfe and Morris's (1996) 1:100,000-scale geologic map shows the subaerial traces of the Kealakekua fault system as concealed by Holocene volcanic units. At Kealakelua Bay, the fault trace is shown inferred as much as about $0.5 \mathrm{~km}$ offshore of the steep coastal scarp.

Digital trace From the 1:100,000-scale map of Wolfe and Morris (1996), available in digital format from Trusdell and others (2006), generalized for this compilation.

Average strike (azimuth) N. $16^{\circ}$ W. $\pm 33^{\circ} ;-16^{\circ} \pm 33^{\circ}$.

Length $(\mathrm{km}) 29.7$ (end to end); 44.7 (cumulative).

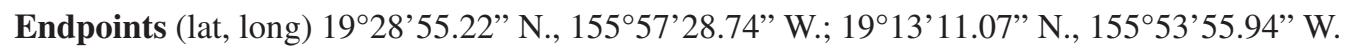

Sense of movement Normal.

Comments: From Wolfe and Morris (1996).

Dip Not reported.

Dip Direction W to SW.

Comments: From Wolfe and Morris (1996).

Geomorphic expression The eight fault traces or zones are concealed normal faults that trend northwest to north with southwest and west hanging wall blocks (Wolfe and Morris, 1996).

Age of faulted deposits Wolfe and Morris (1996) indicate that the subaerial traces of the Kealakekua fault system are concealed by overlying mapped volcanic units (mainly flows) that are $10 \mathrm{ka}$ or younger. Lipman (1995) determined that lava flows exposed in the Kealakekua landslide fault scarp have a K-Ar age of 166 $\pm 63 \mathrm{ka}$. Moore and others (1989) bracket faulting on the Kealakekua fault system between $31 \mathrm{ka}$ and 13-16 ka, based on a 31 ka lava sequence cut by the fault. The fault is overlain by an unfaulted coral reef, with an age of $13 \mathrm{ka}$ (Lipman and others, 1988) or $16 \mathrm{ka}$ (Moore and others, 1990). Moore and Chadwick (1995) interpret the 'Ālika debris avalanches to have occurred prior to about $30 \mathrm{ka}$, the estimated general age of the oldest surface rocks found on Hualālai and Mauna Loa, which show no evidence of tsunami deposits or faulting. Movement of the 'Ālika 2 debris avalanche may have produced 105-ka tsunami deposits on the Island of Lāna'i (Moore and Chadwick, 1995). 
Timing of most recent paleoevent Late Quaternary $(<130 \mathrm{ka})$.

Comments: Herein considered to be constrained between about 31 ka and 13-16 ka (Lipman, 1995; Lipman and others, 1988; Moore and Chadwick, 1995).

\section{Recurrence interval Not reported.}

Slip rate Unknown; probably $<0.2 \mathrm{~mm} / \mathrm{yr}$.

Comments: Herein considered to be $<0.2 \mathrm{~mm} / \mathrm{yr}$ based on a lack of Holocene movement with the most recent movement constrained between about $31 \mathrm{ka}$ and 13-16 ka (Lipman, 1995; Lipman and others, 1988; Moore and Chadwick, 1995). The faults seem to be controlled by catastrophic volcanic-flank failure events that generated the submarine debris avalanches and slumps offshore. Slip rates most likely are not uniform over time and are punctuated by catastrophic faulting events.

\section{References}

Lipman, P.W., 1995, Declining growth of Mauna Loa during the last 100,000 years-Rates of lava accumulation vs. gravitational subsidence, in Rhodes, J.M., and Lockwood, J.P., eds., Mauna Loa revealed-Structure, composition, history, and hazards: American Geophysical Union Geophysical Monograph, v. 92, p. 45-80.

Lipman, P.W., Normark, W.R., Moore, J.G., Wilson, J.B., and Gutmacher, C.E., 1988, The giant submarine Alika debris slide, Mauna Loa Volcano, Hawaii: Journal of Geophysical Research, v. 93, no. B5, p. 4,279-4,299.

Lipman, P.W., Rhodes, J.M., and Dalrymple, G.B., 1990, The Ninole Basalt-Implications for the structural evolution of Mauna Loa Volcano, Hawaii: Bulletin of Volcanology, v. 53, no. 1, p. 1-19.

Moore, J.G., Bryan, W.B., Beeson, M.H., and Normark, W.R., 1995, Giant blocks in the South Kona landslide, Hawaii: Geology, v. 23 , no. 2 , p. $125-128$.

Moore, J.G., and Chadwick, W.W., Jr., 1995, Offshore geology of Mauna Loa and adjacent areas, Hawaii, in Rhodes, J.M., and Lockwood, J.P., eds., Mauna Loa revealed-Structure, composition, history, and hazards: American Geophysical Union Geophysical Monograph, v. 92, p. 21-44.

Moore, J.G., Clague, D.A., Holcomb, R.T., Lipman, P.W., Normark, W.R., and Torresan, M.E., 1989, Prodigious submarine landslides on the Hawaiian Ridge: Journal of Geophysical Research, v. 94, no. B12, p. 17,465-17,484.

Moore, J.G., Normark, W.R., and Szabo, B.J., 1990, Reef growth and volcanism on the submarine southwest rift zone of Mauna Loa, Hawaii: Bulletin of Volcanology, v. 52, 375-380.

Okubo, P.G., 1995, A seismological framework for Mauna Loa Volcano, Hawaii, in Rhodes, J.M., and Lockwood, J.P., eds., Mauna Loa revealed-Structure, composition, history, and hazards: American Geophysical Union Geophysical Monograph, v. 92 , p. $187-197$.

Trusdell, F.A., Wolfe, E.W., and Morris, J., 2006, Digital database of the geologic map of the island of Hawai 'i: U.S. Geological Survey Data Series 144, supplement to Miscellaneous Investigations Series Map I-2524-A, 18 p., 1 sheet, scale 1:100,000.

Wolfe, E.W., and Morris, J., 1996, Geologic map of the island of Hawaii: U.S. Geological Survey Miscellaneous Investigations Series Map I-2524-A, 18 p., 3 sheets, scale 1:100,000.

\section{4, Kahuku Fault System}

Structure number 2604.

Comments: See figure 1 for the location map of the Kahuku fault system in the southern part of the Island of Hawai ${ }^{\circ}$.

Structure name Kahuku fault system.

Comments: The Kahuku fault system is located on Sheet 3 of 3 of the 1:100,000-scale geologic map compiled by Wolfe and Morris (1996), available in digital format from Trusdell and others (2006). Wolfe and Morris (1996) name only the Kahuku fault on their map but show six additional fault splays and traces. Lipman (1995) identified the Kahuku fault system on a generalized map of Hawai' $i$. The senior author uses the term "Kahuku fault system" to identify the group of faults containing the Kahuku fault and six additional splays and traces.

Class of structure Not applicable.

Comments: None. 
Synopsis The Kahuku fault system is located on the southwestern part of Mauna Loa Volcano, where Mauna Loa's southwest rift zone [2605c] shifts eastward approximately $5 \mathrm{~km}$. The west-dipping normal faults of the fault system are colocated along crater chains and fissure vents active as recently as 1868 (Wolfe and Morris, 1996). The Kahuku fault system may connect with the Kealakekua fault system [2603] to form the southwest Hawai'i slide complex, possibly buried beneath lava flows on the western flank of Mauna Loa (fig. 1) (Moore and others, 1989; Lipman, 1995). Offshore of Ka Lae (South Point), the normal fault system extends for an additional $20-40 \mathrm{~km}$ to the south, with the hanging wall block down to the west (Fornari, 1987; Moore and Chadwick, 1995). The South Kona slump and Ka Lae East debris avalanche are located to the west of the offshore extension of the Kahuku fault system (Moore and others, 1989; Moore and Chadwick, 1995).

Date of compilation September 16, 2006.

Compiler and affiliation Eric C. Cannon; Roland Bürgmann, University of California Berkeley.

Province Hawaiian-Emperor island-seamount chain.

Geologic setting Mauna Loa is an active shield-stage volcano (Wolfe and Morris, 1996). The most recent eruption occurred in 1984.

State Hawaii.

County Hawaii.

$\mathbf{1}^{\circ} \mathbf{x} \mathbf{2}^{\circ}$ sheet Hawaii, HI, 1:250,000 scale, 1975.

Comments: Located on the Kahuku Ranch and Ka Lae 7.5-minute topographic sheets.

Reliability of location Good.

Comments: Based on the 1:100,000-scale geologic map from Wolfe and Morris (1996). An approximately 160-m-high erosionally modified fault scarp (Lipman, fig. 1, 1995) forms a prominent topographic feature on southern Mauna Loa.

Digital trace From the 1:100,000-scale geologic map of Wolfe and Morris (1996), available in digital format from Trusdell and others (2006), generalized for this compilation.

Average strike (azimuth) N. $12^{\circ}$ W. $\pm 21^{\circ} ;-12^{\circ} \pm 21^{\circ}$.

Length $(\mathrm{km}) 24.0$ (end to end); 37.7 (cumulative).

Comments: The Kahuku fault system extends offshore of Ka Lae (South Point) for a distance of an additional 20-40 km (Fornari, 1987; Moore and Chadwick, 1995).

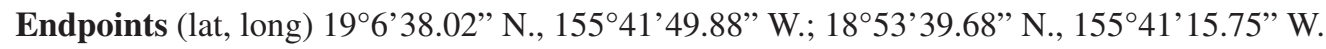

Sense of movement Normal.

Comments: From Wolfe and Morris (1996).

Dip Not reported.

Dip direction W.

Comments: From Moore and Chadwick (1995), Wolfe and Morris (1996).

Geomorphic expression The Kahuku fault is a north-trending, west-side-down, erosionally modified fault scarp with as much as about $160 \mathrm{~m}$ of relief. Offshore, the fault system has almost $2000 \mathrm{~m}$ of vertical offset between the eastern shallow ridge and western downthrown block (Garcia and others, 1995). The South Kona slump and Ka Lae East debris avalanche are located to the west of the eastern shallow ridge (Moore and others, 1989; Moore and Chadwick, 1995).

Age of faulted deposits The fault cuts the Kahuku Basalt which has an estimated age of $>31 \mathrm{ka}$. The Kahuku Basalt is also overlain by unfaulted Pāhala Ash with an estimated age of $>30$ ka (Wolfe and Morris, 1996). 
Timing of most recent paleoevent Late Quaternary $(<130 \mathrm{ka})$.

Comments: Herein considered to be $>30$ ka, the estimated age of the unfaulted Pāhala Ash (Wolfe and Morris, 1996).

\section{Recurrence interval Not reported.}

Slip rate Unknown; probably $<0.2 \mathrm{~mm} / \mathrm{yr}$.

Comments: Herein considered to be $<0.2 \mathrm{~mm} / \mathrm{yr}$ based on a lack of Holocene movement with the most recent movement constrained to be $>30 \mathrm{ka}$ (Wolfe and Morris, 1996). The faults seem to be controlled by catastrophic volcanic-flank failure events that have generated the submarine debris avalanches and slumps offshore. Slip rates most likely are not uniform over time and are punctuated by catastrophic faulting events.

\section{References}

Fornari, D.J., 1987, The geomorphic and structural development of Hawaiian submarine rift zones, in Decker, R.W., Wright, T.L., and Stauffer, P.H., eds., Volcanism in Hawaii: U.S. Geological Survey Professional Paper 1350, v. 1, p. $125-132$. Garcia, M.O., Hulsebosch, T.P., and Rhodes, J.M., 1995, Olivine-rich submarine basalts from the southwest rift zone of Mauna Loa Volcano-Implications for magmatic processes and geochemical evolution, in Rhodes, J.M., and Lockwood, J.P., eds., Mauna Loa revealed-Structure, composition, history, and hazards: American Geophysical Union Geophysical Monograph, v. 92, p. 219-239.

Lipman, P.W., 1995, Declining growth of Mauna Loa during the last 100,000 years—Rates of lava accumulation vs. gravitational subsidence, in Rhodes, J.M., and Lockwood, J.P., eds., Mauna Loa revealed-Structure, composition, history, and hazards: American Geophysical Union Geophysical Monograph, v. 92, p. 45-80.

Moore, J.G., and Chadwick, W.W., Jr., 1995, Offshore geology of Mauna Loa and adjacent areas, Hawaii, in Rhodes, J.M., and Lockwood, J.P., eds., Mauna Loa revealed-Structure, composition, history, and hazards: American Geophysical Union Geophysical Monograph, v. 92, p. 21-44.

Moore, J.G., Clague, D.A., Holcomb, R.T., Lipman, P.W., Normark, W.R., and Torresan, M.E., 1989, Prodigious submarine landslides on the Hawaiian Ridge: Journal of Geophysical Research, v. 94, no. B12, p. 17,465-17,484.

Trusdell, F.A., Wolfe, E.W., and Morris, J., 2006, Digital database of the geologic map of the island of Hawai'i: U.S. Geological Survey Data Series 144, supplement to Miscellaneous Investigations Series Map I-2524-A, 18 p., 1 sheet, scale 1:100,000.

Wolfe, E.W., and Morris, J., 1996, Geologic map of the island of Hawaii: U.S. Geological Survey Miscellaneous Investigations Series Map I-2524-A, 18 p., 3 sheets, scale 1:100,000.

\section{5, Mauna Loa Volcano}

\section{Structure number 2605.}

Comments: See figure 1 for the location map of Mauna Loa Volcano, located mostly in the southern part of the Island of Hawai'i.

Structure name Mauna Loa Volcano.

Comments: Mauna Loa Volcano is located on Sheets 1-3 of 3 of the 1:100,000-scale geologic map compiled by Wolfe and Morris (1996), available in digital format from Trusdell and others (2006).

Synopsis Mauna Loa last erupted in 1984 and is swelling toward its next eruption (D.A. Swanson, written commun., 2005). Faults associated with Mauna Loa include the Kealakekua fault system [2603], Kahuku fault system [2604], Moku 'āweoweo caldera [2605a], northeast rift zone of Mauna Loa [2605b], southwest rift zone of Mauna Loa [2605c], the Ka'öiki seismic zone [2606], and the Ka'öiki-Honu'apo fault system [2607]. The Kealakekua and Kahuku fault systems, the Ka'oiki seismic zone, and the Ka'ōiki-Honu 'apo fault systems are described separately. In addition, several historic eruptions have occurred on Mauna Loa's flanks from radial vents oriented radially to the summit (Trusdell, 1995). The radial vents represent rockbreaking events and their broad distribution on Mauna Loa is not confined to rift zone locations. Plate 1 shows the radial vents based on Wolfe and Morris (1996). Refer to Trusdell (1995) for additional information on volcanic hazards associated with radial vents.

Date of compilation September 16, 2006. 
Compiler and affiliation Eric C. Cannon; Roland Bürgmann, University of California Berkeley.

Province Hawaiian-Emperor island-seamount chain.

Geologic setting Mauna Loa is an active shield-stage volcano (Wolfe and Morris, 1996). The most recent eruption occurred in 1984. Surficial volcanic rocks on Mauna Loa include the Holocene and Pleistocene Ka'ù Basalt (historic eruptions to 10-31 ka), and the Pleistocene Kahuku (>31 ka) and Nīnole (100-300 ka) Basalts (see Wolfe and Morris, 1996). For a detailed history of Holocene eruptions on Mauna Loa, see Lockwood and Lipman (1987). Observations from geodetic networks on Mauna Loa show deformation related to inflation and deflation of the magma reservoir, and southeast motion of the southeast flank (Miklius and others, 1995). The deep canyons of the Nīnole Hills located on the southeast flank may result from rapid incision into headwall landslide scarps related to movement offshore of the Punalu 'u slump (fig. 1) (Lipman and others, 1990; Moore and Chadwick, 1995).

\section{Number of sections 3 .}

Comments: The three sections designated for Mauna Loa Volcano include Moku'āweoweo caldera [2605a], the northeast rift zone [2605b], and the southwest rift zone [2605c].

Average strike (azimuth) N. $33^{\circ}$ E. $\pm 57^{\circ} ;+33^{\circ} \pm 57^{\circ}$.

Length $(\mathrm{km}) 8.5$ (end to end); 129.1 (cumulative).

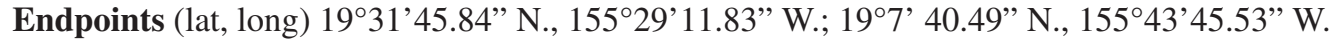

\section{References}

Lipman, P.W., Rhodes, J.M., and Dalrymple, G.B., 1990, The Ninole Basalt_-Implications for the structural evolution of Mauna Loa Volcano, Hawaii: Bulletin of Volcanology, v. 53, no. 1, p. 1-19.

Lockwood, J.P., and Lipman, P.W., 1987, Holocene eruptive history of Mauna Loa Volcano, in Decker, R.W., Wright, T.L., and Stauffer, P.H., eds., Volcanism in Hawaii: U.S. Geological Survey Professional Paper 1350, v. 1, p. 509-535.

Miklius, A., Lisowski, M., Delaney, P.T., Denlinger, R.P., Dvorak, J.J., Okamura, R.T., and Sako, M.K., 1995, Recent inflation and flank movement of Mauna Loa Volcano, in Rhodes, J.M., and Lockwood, J.P., eds., Mauna Loa revealedStructure, composition, history, and hazards: American Geophysical Union Geophysical Monograph, v. 92, p. 199-205.

Moore, J.G., and Chadwick, W.W., Jr., 1995, Offshore geology of Mauna Loa and adjacent areas, Hawaii, in Rhodes, J.M., and Lockwood, J.P., eds., Mauna Loa revealed-Structure, composition, history, and hazards: American Geophysical Union Geophysical Monograph, v. 92, p. 21-44.

Trusdell, F.A., 1995, Lava flow hazards and risk assessment on Mauna Loa Volcano, Hawaii, in Rhodes, J.M., and Lockwood, J.P., eds., Mauna Loa revealed-Structure, composition, history, and hazards: American Geophysical Union Geophysical Monograph, v. 92, p. 327-336.

Trusdell, F.A., Wolfe, E.W., and Morris, J., 2006, Digital database of the geologic map of the island of Hawai 'i: U.S. Geological Survey Data Series 144, supplement to Miscellaneous Investigations Series Map I-2524-A, 18 p., 1 sheet, scale 1:100,000.

Wolfe, E.W., and Morris, J., 1996, Geologic map of the island of Hawaii: U.S. Geological Survey Miscellaneous Investigations Series Map I-2524-A, 18 p., 3 sheets, scale 1:100,000.

\section{5a, Moku‘āweoweo Caldera, Mauna Loa Volcano}

\section{Section number $2605 a$.}

Section name Moku'āweoweo caldera.

Comments: Moku'āweoweo caldera is approximately $8 \mathrm{~km}$ long in the northeast-southwest direction and has a maximum width of $3 \mathrm{~km}$ in the northwest-southeast direction. The caldera is composed of six craters and pits (listed northeast to southwest): North Pit, Lua Pōholo, Moku'āweoweo, South Pit, Lua Hohonu, Lua Hou (Wolfe and Morris, 1996). The northeast rift zone [2605b] continues northeast out of North Pit, and the southwest rift zone [2605c] trends southwest out of South Pit.

Class of structure Not applicable.

Comments: None. 
State Hawaii.

County Hawaii.

$\mathbf{1}^{\circ} \mathbf{x} \mathbf{2}^{\circ}$ sheet Hawaii, HI, 1:250,000 scale, 1975.

Comments: Located on the Mauna Loa 7.5-minute topographic sheet.

Reliability of location Good.

Comments: Based on caldera-concentric and steep caldera and crater wall surficial normal faults (Wolfe and Morris, 1996).

Digital trace From the 1:100,000-scale geologic map compiled by Wolfe and Morris (1996), available in digital format from Trusdell and others (2006), generalized for this compilation.

Average strike (azimuth) N. $28^{\circ}$ E. $\pm 42^{\circ} ;+28^{\circ} \pm 42^{\circ}$.

Comments: Strikes vary on caldera-concentric, steep caldera and crater faults around Moku'āweoweo caldera.

Length $(\mathrm{km}) 7.4$ (end to end); 26.7 (cumulative).

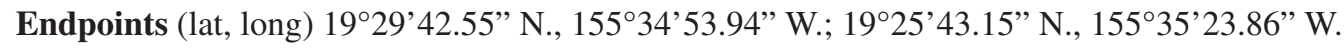

Sense of movement Extension, normal.

Comments: Wolfe and Morris (1996) show surficial normal faulting along caldera-concentric faults southeast of

Moku'āweoweo caldera, and around steep caldera and crater walls.

Dip Not reported.

Dip direction Various.

Comments: Based on northwestern blocks down for surficial normal faulting southeast of Moku'āweoweo caldera (Wolfe and Morris, 1996) and on various strikes of steep caldera and crater wall normal faults.

Geomorphic expression The craters and pits form depressions at the summit of Mauna Loa Volcano producing steep normal faults. Surficial normal faulting along caldera-concentric faults occurs southeast of Moku ‘āweoweo caldera.

Age of faulted deposits The Moku 'āweoweo caldera contains lava flows from historic eruptions in 1880, 1926, 1940, 1942, 1949, and 1975.

Timing of most recent paleoevent Historic (1880-1984).

Comments: The caldera has historically active lava flows, fissure vents, craters, and pits from eruptions in 1880, 1926, 1940, 1942, 1949, 1975, and 1984 (Wolfe and Morris, 1996). The caldera-concentric faults cut lava flows of ages ranging from 200 to $750 \mathrm{yr}$ B.P. and 750 to $1,500 \mathrm{yr}$ B.P. (Wolfe and Morris, 1996).

\section{Recurrence interval Not reported.}

Slip rate $>5 \mathrm{~mm} / \mathrm{yr}$.

Comments: Surface deformation in the Moku'āweoweo caldera is related to inflation and deflation of Mauna Loa's magma reservoir. Miklius and others (1995) summarize the geodetic monitoring efforts on Mauna Loa. Deformation is complex both in time and space. For example, the largest permanent extension between geodetic stations on the rim of Moku 'âweoweo for the time period 1974-1994 was approximately $1.4 \mathrm{~m}$ between stations HVO93 and HVO92, while another pair of stations, HVO93 and ML1, only had about $0.9 \mathrm{~m}$ of permanent extension for the same time period (Miklius and others, 1995). Extension and contraction events were noted for the 1975 and 1984 eruptions. A slip rate of $>5 \mathrm{~mm} / \mathrm{yr}$ is assigned to Moku'āweoweo caldera as a result of observed deformation in the caldera. 


\section{References}

Miklius, A., Lisowski, M., Delaney, P.T., Denlinger, R.P., Dvorak, J.J., Okamura, R.T., and Sako, M.K., 1995, Recent inflation and flank movement of Mauna Loa Volcano, in Rhodes, J.M., and Lockwood, J.P., eds., Mauna Loa revealedStructure, composition, history, and hazards: American Geophysical Union Geophysical Monograph, v. 92, p. 199-205.

Trusdell, F.A., Wolfe, E.W., and Morris, J., 2006, Digital database of the geologic map of the island of Hawai 'i: U.S. Geological Survey Data Series 144, supplement to Miscellaneous Investigations Series Map I-2524-A, 18 p., 1 sheet, scale 1:100,000.

Wolfe, E.W., and Morris, J., 1996, Geologic map of the island of Hawaii: U.S. Geological Survey Miscellaneous Investigations Series Map I-2524-A, 18 p., 3 sheets, scale 1:100,000.

\section{5b, Northeast Rift Zone, Mauna Loa Volcano}

Section number 2605b.

Section name Northeast rift zone.

Comments: Located on Sheets 1-3 of 3 of the 1:100,000-scale geologic map compiled by Wolfe and Morris (1996).

Class of structure Not applicable.

Comments: None.

State Hawaii.

County Hawaii.

$\mathbf{1}^{\circ} \mathbf{x} \mathbf{2}^{\circ}$ sheet Hawaii, HI, 1:250,000 scale, 1975.

Comments: Located on the Koko 'olau, Kūlani, Mauna Loa, Pu'u Maka ‘ala, Pu'u Koli, Pu ‘u 'Ō‘ō, Pu'u O Uo, and Pu'u 'Ula'ula 7.5-minute topographic sheets.

Reliability of location Good.

Comments: Based on the 1:100,000-scale geologic map compiled by Wolfe and Morris (1996).

Digital trace From the 1:100,000-scale geologic map compiled by Wolfe and Morris (1996), available in digital format from Trusdell and others (2006), generalized for this compilation.

Average strike (azimuth) N. $65^{\circ}$ E. $\pm 19^{\circ} ;+65^{\circ} \pm 19^{\circ}$.

Length $(\mathrm{km}) 10.3$ (end to end); 34.0 (cumulative).

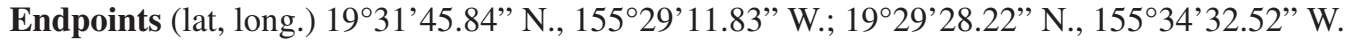

Sense of movement Extension.

Dip Presumably near vertical to vertical.

Dip direction Generally N, S.

Geomorphic expression The northeast rift zone forms a linear topographic high that separates the southern and northern flanks of Mauna Loa.

Age of faulted deposits The majority of the northeast rift zone is situated within historic lava flows from as early as 1843 . The most recent faulted lava flows are from the 1975 eruption. The oldest lava flows with fissure vents identified by Wolfe and Morris (1996) are 5.0-10.0 ka.

Timing of most recent paleoevent Historic (1843-1984).

Comments: Several historic eruptions and lava flows show fissure vents. 
Recurrence interval Not reported.

Slip rate Unknown; probably $>5 \mathrm{~mm} / \mathrm{yr}$. Comments: Miklius and others (1995) report Mauna Loa southeast flank motion of 2-4 cm/yr and greater horizontal motion away from a summit station, based on global positioning system (GPS) surveys carried out between 1993 and 1994-1995. While the GPS network did not extend to the distal part of the northeast rift zone, the observed deformation rates are used to estimate the $>5 \mathrm{~mm} / \mathrm{yr}$ slip rate for the northeast rift zone.

\section{References}

Miklius, A., Lisowski, M., Delaney, P.T., Denlinger, R.P., Dvorak, J.J., Okamura, R.T., and Sako, M.K., 1995, Recent inflation and flank movement of Mauna Loa Volcano, in Rhodes, J.M., and Lockwood, J.P., eds., Mauna Loa revealed—Structure, composition, history, and hazards: American Geophysical Union Geophysical Monograph, v. 92, p. 199-205.

Trusdell, F.A., Wolfe, E.W., and Morris, J., 2006, Digital database of the geologic map of the island of Hawai' 1 i: U.S. Geological Survey Data Series 144, supplement to Miscellaneous Investigations Series Map I-2524-A, 18 p., 1 sheet, scale 1:100,000.

Wolfe, E.W., and Morris, J., 1996, Geologic map of the island of Hawaii: U.S. Geological Survey Miscellaneous Investigations Series Map I-2524-A, 18 p., 3 sheets, scale 1:100,000.

\section{5c, Southwest Rift Zone, Mauna Loa Volcano}

Section number 2605c.

Section name Southwest rift zone.

Comments: The southwest rift zone is located on Sheet 3 of 3 of the 1:100,000-scale geologic map compiled by Wolfe and Morris (1996).

Class of structure Not applicable.

Comments: None.

State Hawaii.

County Hawaii.

$\mathbf{1}^{\circ} \mathbf{x} 2^{\circ}$ sheet Hawaii, HI, 1:250,000 scale, 1975.

Comments: Located on the 'Ālika Cone, Kahuku Ranch, Mauna Loa, Pāpā, Pu'u O Ke'oke'o, Pu 'u 'Ō‘ō, Pu'u Pōhakuloa, $\mathrm{Pu}$ 'u 'Ula'ula, and Sulphur Cone 7.5-minute topographic sheets.

Reliability of location Good.

Comments: Based on the 1:100,000-scale geologic map compiled by Wolfe and Morris (1996).

Digital trace From the 1:100,000-scale geologic map compiled by Wolfe and Morris (1996), available in digital format from Trusdell and others (2006), generalized for this compilation.

Average strike (azimuth) N. $30^{\circ}$ E. $\pm 31^{\circ} ;+30^{\circ} \pm 31^{\circ}$.

Length $(\mathrm{km}) 38.7$ (end to end); 68.4 (cumulative).

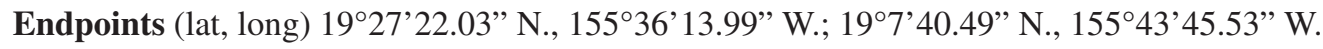
Sense of movement Extension.

Dip Presumably near vertical to vertical.

Dip direction Generally NW, SE to W, E. 
Geomorphic expression The southwest rift zone forms a linear topographic high that separates the southeastern and northwestern flanks of Mauna Loa. On the southwestern flank of Mauna Loa, the southwest rift zone trends south and then shifts approximately $5 \mathrm{~km}$ east to the northern end of the Kahuku fault system [2604]. The distal end of the southwest rift zone and the Kahuku fault system are located at Ka Lae (South Point). Garcia and others (1995) interpret the southwest rift zone axis as located $2-3 \mathrm{~km}$ west of the submarine ridge.

Age of faulted deposits The majority of the southwest rift zone is situated within historic lava flows from as early as 1868 . The most recent faulted lava flows are from the 1950 eruption. The oldest lava flows with fissure vents identified by Wolfe and Morris (1996) are 1.5-3.0 ka.

Timing of most recent paleoevent Historic (1868-1984).

Comments: Several historic eruptions and lava flows show fracturing and faulting.

Recurrence interval Not reported.

Slip rate Unknown; probably $>5 \mathrm{~mm} / \mathrm{yr}$.

Comments: Miklius and others (1995) report southeast flank motion of 2-4 cm/yr and greater horizontal motion away from a summit station, based on global positioning system (GPS) surveys carried out between 1993 and 1994-1995. While the GPS network did not extend to the distal part of the southwest rift zone, the observed deformation rates are used to estimate the $>5 \mathrm{~mm} / \mathrm{yr}$ slip rate for the southwest rift zone.

\section{References}

Garcia, M.O., Hulsebosch, T.P., and Rhodes, J.M., 1995, Olivine-rich submarine basalts from the southwest rift zone of Mauna Loa Volcano-Implications for magmatic processes and geochemical evolution, in Rhodes, J.M., and Lockwood, J.P., eds., Mauna Loa revealed-Structure, composition, history, and hazards: American Geophysical Union Geophysical Monograph, v. 92, p. 219-239.

Miklius, A., Lisowski, M., Delaney, P.T., Denlinger, R.P., Dvorak, J.J., Okamura, R.T., and Sako, M.K., 1995, Recent inflation and flank movement of Mauna Loa Volcano, in Rhodes, J.M., and Lockwood, J.P., eds., Mauna Loa revealedStructure, composition, history, and hazards: American Geophysical Union Geophysical Monograph, v. 92, p. 199-205.

Trusdell, F.A., Wolfe, E.W., and Morris, J., 2006, Digital database of the geologic map of the island of Hawai'i: U.S. Geological Survey Data Series 144, supplement to Miscellaneous Investigations Series Map I-2524-A, 18 p., 1 sheet, scale 1:100,000.

Wolfe, E.W., and Morris, J., 1996, Geologic map of the island of Hawaii: U.S. Geological Survey Miscellaneous Investigations Series Map I-2524-A, 18 p., 3 sheets, scale 1:100,000.

\section{6, Ka'ōiki Seismic Zone}

Structure number 2606.

Comments: See figure 1 for the location map of the Ka'ôiki seismic zone located on the southeastern flank of Mauna Loa Volcano.

Structure name Ka'ōiki seismic zone.

Comments: The Ka'ôiki seismic zone is located on Sheet 3 of 3 of the 1:100,000-scale geologic map compiled by Wolfe and Morris (1996).

Class of structure Not applicable. Comments: None.

Synopsis The Ka'ōiki seismic zone is located on the southeastern flank of Mauna Loa Volcano and is one of the most active seismic zones in Hawai ' $\mathrm{i}$ (Okubo, 1995). The 1974, 1983, and possibly the 1962 Ka'oiki earthquakes are responsible for surface-fault ruptures, a series of en echelon left-stepping fractures (Endo, 1985; Jackson and others, 1992; Wolfe and Morris, 1996).

Date of compilation September 16, 2006. 
Compiler and affiliation Eric C. Cannon; Roland Bürgmann, University of California Berkeley.

Province Hawaiian-Emperor island-seamount chain.

Geologic setting The Ka'oiki seismic zone has a complex faulting history resulting from being located between the active Mauna Loa and Kīlauea Volcanoes (see Jackson and others, 1992). Earthquakes indicate low-angle thrust faulting events, probably related to seaward displacement of the Mauna Loa volcanic edifice, especially prior to Kîlauea's development (Lipman, 1980). Additionally, the similar focal mechanisms for the 1962, 1974, and $1983 \mathrm{Ka}$ 'oiki earthquakes are interpreted to represent right-lateral strike-slip motion on northeast-trending faults (Endo, 1985; Jackson and others, 1992). To the southwest in the adjacent Ka'öiki-Honu'apo fault system [2607], the deep canyons of the Ninole Hills on the southeast flank of Mauna Loa are thought to represent rapid incision into headwall landslide scarps related to the movement offshore of the Punalu'u slump (fig. 1) (Lipman and others, 1990; Moore and Chadwick, 1995).

State Hawaii.

\section{County Hawaii.}

$\mathbf{1}^{\circ} \mathbf{x} \mathbf{2}^{\circ}$ sheet Hawaii, HI, 1:250,000 scale, 1975.

Comments: Located on the Kīpuka Pakēkāke 7.5-minute topographic sheet.

\section{Reliability of location Good.}

Comments: Based on the 1:100,000-scale geologic map compiled by Wolfe and Morris (1996) utilizing fault mapping from Jackson and others (1992).

Digital trace From the 1:100,000-scale geologic map compiled by Wolfe and Morris (1996), available in digital format from Trusdell and others (2006), generalized for this compilation.

Average strike (azimuth) N. $61^{\circ} \mathrm{E} \pm 10^{\circ} ;+61^{\circ} \pm 10^{\circ}$.

Length $(\mathrm{km}) 8.6$ (end to end); 7.1 (cumulative).

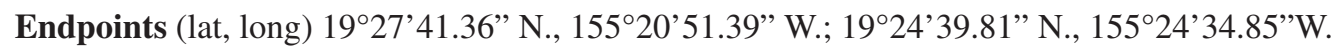

Sense of movement Right-lateral strike-slip.

Comments: Endo (1985) and Jackson and others (1992) interpret focal mechanism solutions from the 1962, 1974, and 1983

Ka'oiki earthquakes and ground fractures from the 1974, 1983, and possibly the $1962 \mathrm{Ka}$ 'ōiki earthquakes to conclude that right-lateral strike-slip movement occurred on faults in the Ka'ōiki seismic zone.

Dip Vertical to $60^{\circ}$.

Comments: Focal mechanism solutions by Endo (1985) and Jackson and others (1992) from the 1962, 1974, and 1983 Ka'ōiki earthquakes and ground fractures from the 1974, 1983, and possibly the $1962 \mathrm{Ka}{ }^{\prime}$ oiki earthquakes suggest that right-lateral strike-slip fault planes are vertical to subvertical. The attitude of the nodal plane interpreted as the fault plane for the 1974 Ka'ōiki earthquake is N. $59^{\circ}$ E., $60^{\circ}$ SE. (Jackson and others, 1992).

Dip Direction Various.

Comments: Refer to Jackson and others (1992) for detailed maps of surficial faulting in the Ka'ōiki seismic zone.

Geomorphic expression The surface fractures are located in basalt lava flows located on the southeast flank of Mauna Loa Volcano.

Age of faulted deposits Latest Pleistocene to Holocene.

Comments: Surface lava flows as young as the 1880-1881 lava flow and as old as 5,000 to 10,000 yr B.P. are cut by fractures (Wolfe and Morris, 1996). 
Timing of most recent paleoevent Historic $(1974,1983)$.

Comments: Jackson and others (1992) interpret ground fractures in the Ka'oiki seismic zone area as having been formed by

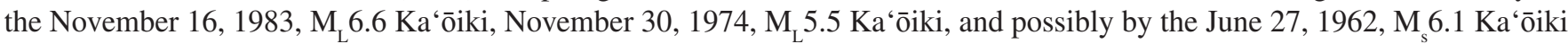
earthquakes (Wyss and Koyanagi, 1992). Jackson and others (1992) do not report ages of prehistoric faulting events. Refer to the descriptions of the 1962, 1974, and 1983 Ka'oiki earthquakes in this compilation for more details on surficial faulting.

\section{Recurrence interval Not reported.}

Slip rate Unknown; probably $>5 \mathrm{~mm} / \mathrm{yr}$. Comments: Jackson and others (1992) do not estimate a slip rate. Delaney and others (1998) summarize the contraction and extension that occurred along the northwest-trending baseline Strip-Uwēkahuna detected in trilateration data collected between November 1975 and 1995. Between the magma reservoir inflation events of September 1977 and August 1981, the baseline contracted approximately $3 \mathrm{~cm} / \mathrm{yr}$. For the time period beginning with the November $1983 \mathrm{Ka}$ 'oiki earthquake through 1995, the baseline extended $2.4 \pm 0.3 \mathrm{~cm} / \mathrm{yr}$. However, the Strip-Uwēkahuna baseline may exhibit deformation from the Ka'ōikiHonu 'apo fault system [2607] and Kîlauea Volcano [2608]. Miklius and others (1995) determine from Global Positioning System (GPS) surveys of Mauna Loa's southeastern flank in 1993 and 1994-1995 that the Ka'oiki seismic zone had 1 microstrain/yr contraction and left-lateral shear. Based on active seismicity and flank deformation observed from geodetic surveys, the slip rate is assigned to be $>5 \mathrm{~mm} / \mathrm{yr}$.

\section{References}

Delaney, P.T., Denlinger, R.P., Lisowski, M., Miklius, A., Okubo, P.G., Okamura, A.T., and Sako, M.K., 1998, Volcanic spreading at Kilauea, 1976-1996: Journal of Geophysical Research, v. 103, no. B8, p. 18,003-18,023.

Endo, E.T., 1985, Seismotectonic framework for the southeast flank of Mauna Loa volcano, Hawaii: Seattle, University of Washington, Ph.D. dissertation, 349 p.

Jackson, M.D., Endo, E.T., Delaney, P.T., Árnadottir, T., and Rubin, A.M., 1992, Ground ruptures of the 1974 and 1983 Kaoiki earthquakes, Mauna Loa Volcano, Hawaii: Journal of Geophysical Research, v. 97, no. B6, p. 8,775-8,796.

Lipman, P.W., 1980, The southwest rift zone of Mauna Loa-Implications for structural evolution of Hawaiian volcanoes: American Journal of Science, v. 280-A, p. 752-776.

Lipman, P.W., Rhodes, J.M., and Dalrymple, G.B., 1990, The Ninole Basalt-Implications for the structural evolution of Mauna Loa Volcano, Hawaii: Bulletin of Volcanology, v. 53, no. 1, p. 1-19.

Miklius, A., Lisowski, M., Delaney, P.T., Denlinger, R.P., Dvorak, J.J., Okamura, R.T., and Sako, M.K., 1995, Recent inflation and flank movement of Mauna Loa Volcano, in Rhodes, J.M., and Lockwood, J.P., eds., Mauna Loa revealedStructure, composition, history, and hazards: American Geophysical Union Geophysical Monograph, v. 92, p. 199-205.

Moore, J.G., and Chadwick, W.W., Jr., 1995, Offshore geology of Mauna Loa and adjacent areas, Hawaii, in Rhodes, J.M., and Lockwood, J.P., eds., Mauna Loa revealed—Structure, composition, history, and hazards: American Geophysical Union Geophysical Monograph, v. 92, p. 21-44.

Okubo, P.G., 1995, A seismological framework for Mauna Loa Volcano, Hawaii, in Rhodes, J.M., and Lockwood, J.P., eds., Mauna Loa revealed-Structure, composition, history, and hazards: American Geophysical Union Geophysical Monograph, v. 92, p. 187-197.

Trusdell, F.A., Wolfe, E.W., and Morris, J., 2006, Digital database of the geologic map of the island of Hawai 'i: U.S. Geological Survey Data Series 144, supplement to Miscellaneous Investigations Series Map I-2524-A, 18 p., 1 sheet, scale $1: 100,000$.

Wolfe, E.W., and Morris, J., 1996, Geologic map of the island of Hawaii: U.S. Geological Survey Miscellaneous Investigations Series Map I-2524-A, 18 p., 3 sheets, scale 1:100,000.

Wyss, M., and Koyanagi, R.Y., 1992, Isoseismal maps, macroseismic epicenters, and estimated magnitudes of historic earthquakes in the Hawaiian Islands: U.S. Geological Survey Bulletin 2006, 93 p.

\section{7, Ka'ōiki-Honu'apo Fault System}

Structure number 2607.

Comments: See figure 1 for the location map of the Ka'oiki-Honu'apo fault system in the southern part of the Island of Hawai'i. 
Structure name Ka'ōiki-Honu'apo fault system.

Comments: The Ka'oiki-Honu'apo fault system is located on Sheets 2 and 3 of 3 of the 1:100,000-scale geologic map compiled by Wolfe and Morris (1996), available in digital format from Trusdell and others (2006).

Class of structure Not applicable.

Comments: None.

Synopsis The Ka'ōiki-Honu 'apo fault system is located along the southeastern flank of Mauna Loa Volcano. The northeast end is adjacent to the Ka'oiki seismic zone [2606].

Date of compilation September 16, 2006.

Compiler and affiliation Eric C. Cannon; Roland Bürgmann, University of California Berkeley.

Province Hawaiian-Emperor island-seamount chain.

Geologic setting The Ka'ōiki-Honu 'apo fault system has a complex faulting history because it is located between the active Mauna Loa and Kīlauea Volcanoes (see Jackson and others, 1992). Earthquakes indicate low-angle thrust-faulting events, probably related to seaward displacement of the Mauna Loa volcanic edifice, especially prior to Kîlauea's development (Lipman, 1980). Additionally, the similar focal mechanisms for the 1962, 1974, and $1983 \mathrm{Ka}$ 'oiki earthquakes in the adjacent Ka'ōiki seismic zone [2606] are interpreted to represent right-lateral strike-slip motion on northeast-trending faults (Endo, 1985; Jackson and others, 1992). In the southwest region, the deep canyons of the Ninole Hills on the southeast flank of Mauna Loa are thought to represent rapid incision into headwall landslide scarps related to movement offshore of the Punalu ' $u$ slump (fig. 1) (Lipman and others, 1990; Moore and Chadwick, 1995).

State Hawaii.

County Hawaii.

$\mathbf{1}^{\circ} \mathbf{x} 2^{\circ}$ sheet Hawaii, HI, 1:250,000 scale, 1975.

Comments: Located on the Kahuku Ranch, Kea 'īwa Reservoir, Kīlauea Crater, Kīpuka Pakēkāke, Mauna Loa, Nā‘ālehu, Pāhala, Pu'u O Ke'oke'o, Punalu 'u, and Wood Valley 7.5-minute topographic sheets.

Reliability of location Poor.

Comments: Based on the mostly concealed fault traces identified on the 1:100,000-scale geologic map compiled by Wolfe and Morris (1996).

Digital trace From the 1:100,000-scale geologic map compiled by Wolfe and Morris (1996), available in digital format from Trusdell and others (2006), generalized for this compilation.

Average strike (azimuth) N. $25^{\circ}$ E. $\pm 42^{\circ} ;+25^{\circ} \pm 42^{\circ}$.

Length $(\mathrm{km}) 57.6$ (end to end); 304.8 (cumulative).

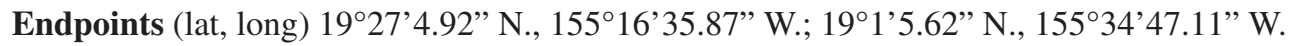

\section{Sense of movement Normal.}

Comments: The geomorphic scarps generally trend northeast to east with southeast- to south-side down hanging-wall blocks. In the southwest at Waikapuna, surficial normal faults generally trend northwest and have either northeast- or southwest-side down hanging-wall blocks.

Dip Not reported.

Dip Direction SE to E, NE and SW.

Comments: From surficial and concealed normal faults (Wolfe and Morris, 1996). 
Geomorphic expression Geomorphic scarps result from faulted late Pleistocene- to Holocene-age lava flows that are locally draped by younger lava flows. Jackson and others (1992) state that some scarps in the Ka'oiki area represent more than $100 \mathrm{~m}$ of vertical displacement and that most scarps are draped by unfaulted Mauna Loa basalt flows.

Age of faulted deposits Latest Pleistocene to Holocene.

Comments: In the far southwestern region, surficial faults cut lava flows as young as 3,000-5,000 yr B.P. (Wolfe and Morris, 1996). For the majority of the fault system, geomorphic scarps are overlain by unfaulted 200-750 yr B.P. to 3,000-5,000 yr B.P. lava flows (Wolfe and Morris, 1996).

Timing of most recent paleoevent $<15 \mathrm{ka}$.

Comments: Many of the concealed and inferred faults probably have been active in the Holocene, draped by unfaulted younger lava flows. Surficial faults in the southwest cut 3,000-5,000 yr B.P. Mauna Loa lava flows (Wolfe and Morris, 1996). To the northeast in the Ka'ōiki seismic zone [2606], Jackson and others (1992) interpret ground fractures in the Ka'ōiki area as having been formed by the November 16, 1983, $\mathrm{M}_{\mathrm{L}} 6.6 \mathrm{Ka}$ 'ōiki earthquake at 06:13 a.m. local time (Hawaiian Standard Time; Wyss and Koyanagi, 1992). Refer to the description of the November 16, 1983, Ka'oiki earthquake and the November 30 , $1974, \mathrm{M}_{\mathrm{L}} 5.5 \mathrm{Ka}$ 'oiki earthquake in this report for details of surficial faulting.

\section{Recurrence interval Not reported.}

Slip rate Unknown; probably $1-5 \mathrm{~mm} / \mathrm{yr}$. Comments: Jackson and others (1992) do not estimate a slip rate. The estimate of 1-5 mm/yr is based on large scarp heights for geomorphic scarps overlain by unfaulted late Holocene lava flows.

\section{References}

Endo, E.T., 1985, Seismotectonic framework for the southeast flank of Mauna Loa volcano, Hawaii: Seattle, University of Washington, Ph.D. dissertation, 349 p.

Jackson, M.D., Endo, E.T., Delaney, P.T., Árnadottir, T., and Rubin, A.M., 1992, Ground ruptures of the 1974 and 1983 Kaoiki earthquakes, Mauna Loa Volcano, Hawaii: Journal of Geophysical Research, v. 97, no. B6, p. 8,775-8,796.

Lipman, P.W., 1980, The southwest rift zone of Mauna Loa-Implications for structural evolution of Hawaiian volcanoes: American Journal of Science, v. 280-A, p. 752-776.

Lipman, P.W., Rhodes, J.M., and Dalrymple, G.B., 1990, The Ninole Basalt-Implications for the structural evolution of Mauna Loa Volcano, Hawaii: Bulletin of Volcanology, v. 53, no. 1, p. 1-19.

Moore, J.G., and Chadwick, W.W., Jr., 1995, Offshore geology of Mauna Loa and adjacent areas, Hawaii, in Rhodes, J.M., and Lockwood, J.P., eds., Mauna Loa revealed—Structure, composition, history, and hazards: American Geophysical Union Geophysical Monograph, v. 92, p. 21-44.

Trusdell, F.A., Wolfe, E.W., and Morris, J., 2006, Digital database of the geologic map of the island of Hawai'i: U.S. Geological Survey Data Series 144, supplement to Miscellaneous Investigations Series Map I-2524-A, 18 p., 1 sheet, scale $1: 100,000$.

Wolfe, E.W., and Morris, J., 1996, Geologic map of the island of Hawaii: U.S. Geological Survey Miscellaneous Investigations Series Map I-2524-A, 18 p., 3 sheets, scale 1:100,000.

Wyss, M., and Koyanagi, R.Y., 1992, Isoseismal maps, macroseismic epicenters, and estimated magnitudes of historic earthquakes in the Hawaiian Islands: U.S. Geological Survey Bulletin 2006, 93 p.

\section{8, Kīlauea Volcano}

Structure number 2608.

Comments: See figure 1 for the location map of Kîlauea Volcano located in the southeastern part of the Island of Hawai' $i$.

Structure name Kīlauea Volcano.

Comments: Neal and Lockwood (2003) present a 1:24,000-scale geologic map of the Kîlauea summit region. Kîlauea Volcano is also located on Sheets 2 and 3 of 3 of the 1:100,000-scale geologic map compiled by Wolfe and Morris (1996), available in digital format from Trusdell and others (2006). 
Synopsis Kīlauea Volcano is the youngest subaerial volcano in Hawai 'i. Kỉlauea's extensional structures include Kîlauea's caldera [2608a], the east rift zone [2608b], and the southwest rift zone [2608c]. Two additional fault systems are located to the southeast of Kîlauea's caldera: the Koa'e fault system [2609], and the Hilina fault system [2610]. The senior author assigns the Koa' $e$ and Hilina fault systems their own fault numbers rather than grouping these faults into a single extensional feature for Kīlauea. Another categorization scheme by Delaney and others (1998) subdivides Kîlauea Volcano into four geographic regions: (1) western south flank and lower southwest rift zone, (2) summit and upper rift zones, (3) middle east rift zone, and (4) central and eastern south flank.

Along the coast and offshore of Killauea's south flank to the southeast, the Hilina fault system [2610] may define the headscarps to the submarine Hilina slump and subsequent Pāpa 'u sand-rubble flow (fig. 1) (see Moore and others, 1989; Moore and Chadwick, 1995).

Date of compilation September 16, 2006.

Compiler and affiliation Eric C. Cannon; Roland Bürgmann, University of California Berkeley.

Province Hawaiian-Emperor island-seamount chain.

Geologic setting Kīlauea Volcano is an active shield-stage volcano (Wolfe and Morris, 1996) situated on the southeast flank of older Mauna Loa Volcano [2605].

\section{Number of sections 3.}

Comments: The three sections designated for Kîlauea Volcano are Kîlauea's caldera [2608a], the east rift zone [2608b], and the southwest rift zone [2608c].

Average strike (azimuth) N. $51^{\circ}$ E. $\pm 46^{\circ} ;+51^{\circ} \pm 46^{\circ}$.

Length $(\mathrm{km}) 75.9$ (end to end); 140.7 (cumulative).

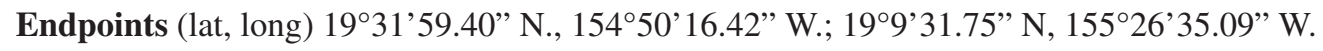

\section{References}

Delaney, P.T., Denlinger, R.P., Lisowski, M., Miklius, A., Okubo, P.G., Okamura, A.T., and Sako, M.K., 1998, Volcanic spreading at Kilauea, 1976-1996: Journal of Geophysical Research, v. 103, no. B8, p. 18,003-18,023.

Moore, J.G., and Chadwick, W.W., Jr., 1995, Offshore geology of Mauna Loa and adjacent areas, Hawaii, in Rhodes, J.M., and Lockwood, J.P., eds., Mauna Loa revealed—Structure, composition, history, and hazards: American Geophysical Union Geophysical Monograph, v. 92, p. 21-44.

Moore, J.G., Clague, D.A., Holcomb, R.T., Lipman, P.W., Normark, W.R., and Torresan, M.E., 1989, Prodigious submarine landslides on the Hawaiian Ridge: Journal of Geophysical Research, v. 94, no. B12, p. 17,465-17,484.

Neal, C.A. and Lockwood, J.P., 2003, Geologic map of the summit region of Kīlauea Volcano, Hawaii: U.S. Geological Survey Geologic Investigations Series I-2759, 14 p., 1 sheet, scale 1:24,000.

Trusdell, F.A., Wolfe, E.W., and Morris, J., 2006, Digital database of the geologic map of the island of Hawai' $i$ i: U.S. Geological Survey Data Series 144, supplement to Miscellaneous Investigations Series Map I-2524-A, 18 p., 1 sheet, scale $1: 100,000$.

Wolfe, E.W., and Morris, J., 1996, Geologic map of the island of Hawaii: U.S. Geological Survey Miscellaneous Investigations Series Map I-2524-A, 18 p., 3 sheets, scale 1:100,000.

\section{8a, Kīlauea's Caldera, Kīlauea Volcano}

Section number 2608a.

Section name Kīlauea's caldera.

Class of structure Not applicable.

Comments: None. 
State Hawaii.

County Hawaii.

$\mathbf{1}^{\circ} \mathbf{x} \mathbf{2}^{\circ}$ sheet Hawaii, HI, 1:250,000 scale, 1975.

Comments: Located on the Kîlauea Crater and Volcano 7.5-minute topographic sheets.

Reliability of location Good.

Comments: Based on 1:24,000-scale geologic mapping of surficial and concealed faults by Neal and Lockwood (2003).

Digital trace From the 1:24,000-scale geologic map of Neal and Lockwood (2003), generalized for this compilation. Also, the smaller scale 1:100,000-scale geologic map of Wolfe and Morris (1996) is available in digital format from Trusdell and others (2006).

Average strike (azimuth) N. $51^{\circ}$ E. $\pm 77^{\circ} ;+51^{\circ} \pm 77^{\circ}$.

Comments: Strikes vary because of caldera-concentric faults around Kīlauea's caldera.

Length $(\mathrm{km}) 6.9$ (end to end); 31.6 (cumulative).

Comments: Many caldera-concentric faults exist around Kīlauea's caldera, potentially yielding at least $30 \mathrm{~km}$ of surficial and concealed fault traces.

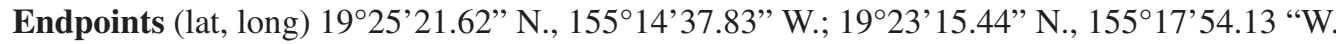

Sense of movement Normal.

Comments: Neal and Lockwood (2003) show surficial and concealed normal faults located around and crossing Kīlauea's caldera.

Dip Not reported.

Dip direction Various.

Comments: Based on various strikes of caldera-concentric faults from Neal and Lockwood (2003).

Geomorphic expression Kîlauea's caldera is approximately $7 \mathrm{~km}$ long in the east-west direction by $5 \mathrm{~km}$ wide in the north-south direction at the summit of Kīlauea Volcano. The major craters contained within this region include Kîlauea Crater, Halema 'uma'u Crater, Kīlauea Iki Crater, and Keanakāko'i Crater. The maximum relief of Kîlauea's caldera is approximately $210 \mathrm{~m}$ (about 700 feet). Many of the steep walls of Kīlauea's caldera are interpreted as concealed normal faults (Neal and Lockwood, 2003). Additionally, several concealed and some surficial caldera-concentric normal faults are located distally away from the crater rims (Neal and Lockwood, 2003).

Age of faulted deposits Neal and Lockwood (2003) state that most caldera-concentric faults are buried or draped by lava flows dating from 1790 and younger, or by the 1790 Keanakāko ‘ $i$ Ash Member. Pre-1790 basalts exposed at the surface range in age from around $200 \mathrm{yr}$ B.P. to possibly 3,000 yr B.P. Additional resources for lava flow ages include Holcomb (1987) and Wolfe and Morris (1996).

Timing of most recent paleoevent Holocene and latest Pleistocene ( $<15 \mathrm{ka})$.

Comments: With most of the caldera-concentric faults buried or draped by lava flows (dating from 1790 and younger) or by the 1790 Keanakāko'i Ash Member, Neal and Lockwood (2003) attribute caldera-concentric normal faulting to caldera collapse sometime between approximately 200 and 500 years ago. The present caldera formed in approximately 1490 with evidence of at least $500 \mathrm{~m}$ of vertical displacement (D.A. Swanson, written commun., 2005). Induced ground shaking caused by the November 16, 1983, $\mathrm{M}_{\mathrm{L}} 6.6 \mathrm{Ka}$ 'öiki earthquake produced ground failures on steep slopes and movement on preexisting fractures (Buchanan-Banks, 1987; Wyss and Koyanagi, 1992), but did not produce faulting on the caldera-concentric faults. Refer to the description of the November 16, 1983, Ka'oiki earthquake in this compilation for more details.

Recurrence interval Not reported. 
Slip rate Unknown; probably $>5 \mathrm{~mm} / \mathrm{yr}$.

Comments: While the caldera-concentric faults have remained inactive over approximately the last 200-500 yrs, modern geodetic baselines recording extension and contraction adjacent to and within Kîlauea's caldera show deformation that results from magma reservoir inflation and deflation as well as seaward displacement of Kīlauea's south flank. For example, benchmark HVO34 located in the southwestern part of Killauea's caldera had approximately $2 \mathrm{~m}$ of uplift over the time period from 1965 to the 1975 Kalapana earthquake. After the earthquake, HVO34 displayed subsidence at approximately $8 \mathrm{~cm} / \mathrm{yr}$ through 1996 (Delaney and others, 1998). See Delaney and others (1998) for a discussion of deformation and deformation rates for Kîlauea Volcano from 1976-1996. The estimated slip rate of $>5 \mathrm{~mm} / \mathrm{yr}$ for caldera-concentric faults is based on modern geodetic baseline deformation rates.

\section{References}

Buchanan-Banks, J.M., 1987, Structural damage and ground failures from the November 16, 1983, Kaoiki earthquake, Island of Hawaii, in Decker, R.W., Wright, T.L., and Stauffer, P.H., eds., Volcanism in Hawaii: U.S. Geological Survey Professional Paper 1350, v. 2, p. 1,187-1,220.

Delaney, P.T., Denlinger, R.P., Lisowski, M., Miklius, A., Okubo, P.G., Okamura, A.T., and Sako, M.K., 1998, Volcanic spreading at Kilauea, 1976-1996: Journal of Geophysical Research, v. 103, no. B8, p. 18,003-18,023.

Holcomb, R.T., 1987, Eruptive history and long-term behavior of Kilauea Volcano, in Decker, R.W., Wright, T.L., and Stauffer, P.H., eds., Volcanism in Hawaii: U.S. Geological Survey Professional Paper 1350, v. 1, p. 261-350.

Neal, C.A., and Lockwood, J.P., 2003, Geologic map of the summit region of Kīlauea Volcano, Hawaii: U.S. Geological Survey Geologic Investigations Series I-2759, 14 p., 1 sheet, scale 1:24,000.

Trusdell, F.A., Wolfe, E.W., and Morris, J., 2006, Digital database of the geologic map of the island of Hawai 'i: U.S. Geological Survey Data Series 144, supplement to Miscellaneous Investigations Series Map I-2524-A, 18 p., 1 sheet, scale $1: 100,000$.

Wolfe, E.W., and Morris, J., 1996, Geologic map of the island of Hawaii: U.S. Geological Survey Miscellaneous Investigations Series Map I-2524-A, 18 p., 3 sheets, scale 1:100,000.

Wyss, M., and Koyanagi, R.Y., 1992, Isoseismal maps, macroseismic epicenters, and estimated magnitudes of historic earthquakes in the Hawaiian Islands: U.S. Geological Survey Bulletin 2006, 93 p.

\section{8b, East Rift Zone, Kīlauea Volcano}

Section number $2608 \mathrm{~b}$.

Section name East rift zone.

Class of structure Not applicable.

Comments: Geodetic data indicates ongoing deformation.

State Hawaii.

County Hawaii.

$\mathbf{1}^{\circ} \mathbf{x} \mathbf{2}^{\circ}$ sheet Hawaii, HI, 1:250,000 scale, 1975.

Comments: The east rift zone is located on the Kalalua, Kapoho, Kīlauea Crater, Makaopuhi Crater, Pāhoa South, and Volcano 7.5-minute topographic sheets.

Reliability of location Good.

Comments: The 1:100,000-scale geologic map compiled by Wolfe and Morris (1996) shows surficial fissure vents, faults, and open cracks.

Digital trace From the 1:100,000-scale geologic map compiled by Wolfe and Morris (1996), available in digital form from Trusdell and others (2006), generalized for this compilation.

Average strike (azimuth) N. $67^{\circ}$ E. $\pm 10^{\circ} ;+67^{\circ} \pm 10^{\circ}$. 
Length $(\mathrm{km}) 45.2$ (end to end); 55.2 (cumulative).

Comments: The subaerial east rift zone continues offshore northeast of Cape Kumukahi as the 70-km-long submerged Puna Ridge (fig. 1) (see Moore and Chadwick, 1995).

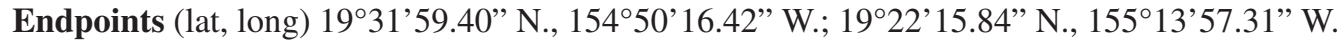

Sense of movement Extension, normal.

Comments: From Wolfe and Morris (1996).

Dip Not reported.

Dip direction NW, SE, presumably vertical.

Comments: From Wolfe and Morris (1996), some northeast-striking normal fault traces show hanging wall blocks down to either the northwest or to the southeast.

Geomorphic expression Fissure vents and open cracks generally trend northeast along the east rift zone (Wolfe and Morris, 1996). Along the submarine Puna Ridge, fissure vents trend N. $45^{\circ}$ E. along the crest of the ridge (see Fornari, 1987). The North Puna Ridge debris avalanches flow northward off the submarine ridge (fig. 1). Other debris avalanches may exist, but bathymetric data is limited (see Moore and Chadwick, 1995).

Age of faulted deposits Surface lava flows ranging in age from 20th century to 750-1,500 yr B.P. are cut by faults (Wolfe and Morris, 1996). See Holcomb (1987) for details of ages and names of individual lava flows.

Timing of most recent paleoevent Historic (1989, 1998-1999).

Comments: The Kea'au-Heiheiahulu baseline across the east rift zone extended about $20 \mathrm{~cm}$ probably due to the June 25 , 1989, M 6.1 Kalapana earthquake (Wyss and Koyanagi, 1992; Delaney and others, 1998). Refer to the description of the June 25, 1983, Kalapana earthquake in this compilation for more details. Cracks have opened as recently as 1998-1999 (D.A. Swanson, written commun., 2005).

\section{Recurrence interval Not reported.}

Slip rate $>5 \mathrm{~mm} / \mathrm{yr}$.

Comments: Geodetic baselines across the east rift zone show variable extension over time. Looking at extension averaged over 1986-1989, baselines Kea'au-Heiheiahulu and Kaloli2-Kapoho have average extension rates of $2.2 \pm 0.3 \mathrm{~cm} / \mathrm{yr}$ and $0.7 \pm 0.5 \mathrm{~cm} / \mathrm{yr}$, respectively, with extension rates decreasing eastward along the east rift zone (Delaney and others, 1998). The Kea'au-Heiheiahulu baseline extended approximately $20 \mathrm{~cm}$, probably due to the June 25, 1989, $\mathrm{M}_{\mathrm{L}} 6.1$ Kalapana earthquake (Wyss and Koyanagi, 1992; Delaney and others, 1998). See Delaney and others (1998) for a discussion of spreading rates for the east rift zone from 1976-1995. The estimated slip rate of $>5 \mathrm{~mm} / \mathrm{yr}$ for the east rift zone is based on geodetic baseline deformation rates as an approximation for longer-term fault slip rates.

\section{References}

Delaney, P.T., Denlinger, R.P., Lisowski, M., Miklius, A., Okubo, P.G., Okamura, A.T., and Sako, M.K., 1998, Volcanic spreading at Kilauea, 1976-1996: Journal of Geophysical Research, v. 103, no. B8, p. 18,003-18,023.

Fornari, D.J., 1987, The geomorphic and structural development of Hawaiian submarine rift zones, in Decker, R.W., Wright, T.L., and Stauffer, P.H., eds., Volcanism in Hawaii: U.S. Geological Survey Professional Paper 1350, v. 1, p. $125-132$.

Holcomb, R.T., 1987, Eruptive history and long-term behavior of Kilauea Volcano, in Decker, R.W., Wright, T.L., and Stauffer, P.H., eds., Volcanism in Hawaii: U.S. Geological Survey Professional Paper 1350, v. 1, p. 261-350.

Moore, J.G., and Chadwick, W.W., Jr., 1995, Offshore geology of Mauna Loa and adjacent areas, Hawaii, in Rhodes, J.M., and Lockwood, J.P., eds., Mauna Loa revealed-Structure, composition, history, and hazards: American Geophysical Union Geophysical Monograph, v. 92, p. 21-44.

Trusdell, F.A., Wolfe, E.W., and Morris, J., 2006, Digital database of the geologic map of the island of Hawai 'i: U.S. Geological Survey Data Series 144, supplement to Miscellaneous Investigations Series Map I-2524-A, 18 p., 1 sheet, scale $1: 100,000$. 
Wolfe, E.W., and Morris, J., 1996, Geologic map of the island of Hawaii: U.S. Geological Survey Miscellaneous Investigations Series Map I-2524-A, 18 p., 3 sheets, scale 1:100,000.

Wyss, M., and Koyanagi, R.Y., 1992, Isoseismal maps, macroseismic epicenters, and estimated magnitudes of historic earthquakes in the Hawaiian Islands: U.S. Geological Survey Bulletin 2006, 93 p.

\section{8c, Southwest Rift Zone, Kīlauea Volcano}

\section{Section number $2608 \mathrm{c}$.}

Section name Southwest rift zone.

Class of structure Not applicable.

Comments: Geodetic data indicate ongoing deformation.

State Hawaii.

County Hawaii.

$\mathbf{1}^{\circ} \times \mathbf{2}^{\circ}$ sheet Hawaii, HI, 1:250,000 scale, 1975.

Comments: The southwest rift zone is located on the Ka'ū Desert, Kīlauea Crater, Pāhala, and Wood Valley 7.5-minute topographic sheets.

\section{Reliability of location Good.}

Comments: The 1:100,000-scale geologic map compiled by Wolfe and Morris (1996) shows surficial fissure vents, faults, and open cracks.

Digital trace From the 1:100,000-scale geologic map compiled by Wolfe and Morris (1996), available in digital form from Trusdell and others (2006), generalized for this compilation.

Average strike (azimuth) N. $34^{\circ}$ E. $\pm 19^{\circ} ;+34^{\circ} \pm 19^{\circ}$.

Length $(\mathrm{km}) 30.4$ (end to end); 53.9 (cumulative).

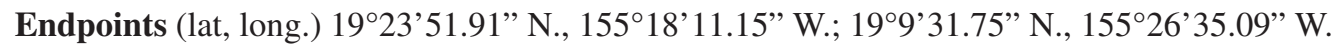

Sense of movement Extension, normal.

Comments: From Wolfe and Morris (1996).

Dip Not reported.

Dip direction NW, SE, presumably vertical.

Comments: From Wolfe and Morris (1996), some northeast-striking normal fault traces show hanging wall blocks down to either the northwest or to the southeast.

Geomorphic expression Open cracks, fissure vents, and normal faults generally trend northeast along the southwest rift zone (Wolfe and Morris, 1996).

Age of faulted deposits Surface lava flows ranging in age from $20^{\text {th }}$ century to $1,500-3,000$ yr B.P. are cut by faults (Wolfe and Morris, 1996). See Holcomb (1987) for more details on ages and names of individual lava flows.

Timing of most recent paleoevent Historic (1983).

Comments: Modern seismic events for the southwest rift zone includes seismic swarms related to intrusions in August 1981 and June 1982, and the November 16, 1983, M 6.6 Ka'öiki earthquake (Wyss and Koyanagi, 1992; Delaney and others, 1998). Delaney and others (1998) state that extension across the southwest rift zone has probably occurred since 1984, whereas between 1976-1984, some locations along the southwest rift zone had extension while other locations had compression. Refer to the description of the November 16, 1983, Ka'öiki earthquake in this compilation for more details. 
Recurrence interval Not reported.

Slip rate $>5 \mathrm{~mm} / \mathrm{yr}$.

Comments: The geodetic baseline across the southwest rift zone shows variable extension over time. The maximum horizontal extension rate observed at baseline Keakapulu-HVO128 for the time period from November 1984 to 1996 (after the November 16, 1983, Ka'ōiki earthquake) is approximately $3 \mathrm{~cm} / \mathrm{yr}$ (Delaney and others, 1998). However, the baseline extended $80 \mathrm{~cm}$ due to the August 1981 seismic swarm (Delaney and others, 1998). See Delaney and others (1998) for a discussion of spreading rates for Kîlauea Volcano from 1976-1996. The estimated slip rate of $>5 \mathrm{~mm} / \mathrm{yr}$ for the southwest rift zone is based on geodetic baseline deformation rates as an approximation for longer-term fault slip rates.

\section{References}

Delaney, P.T., Denlinger, R.P., Lisowski, M., Miklius, A., Okubo, P.G., Okamura, A.T., and Sako, M.K., 1998, Volcanic spreading at Kilauea, 1976-1996: Journal of Geophysical Research, v. 103, no. B8, p. 18,003-18,023.

Holcomb, R.T., 1987, Eruptive history and long-term behavior of Kilauea Volcano, in Decker, R.W., Wright, T.L., and Stauffer, P.H., eds., Volcanism in Hawaii: U.S. Geological Survey Professional Paper 1350, v. 1, p. 261-350.

Trusdell, F.A., Wolfe, E.W., and Morris, J., 2006, Digital database of the geologic map of the island of Hawai ‘i: U.S. Geological Survey Data Series 144, supplement to Miscellaneous Investigations Series Map I-2524-A, 18 p., 1 sheet, scale 1:100,000.

Wolfe, E.W., and Morris, J., 1996, Geologic map of the island of Hawaii: U.S. Geological Survey Miscellaneous Investigations Series Map I-2524-A, 18 p., 3 sheets, scale 1:100,000.

Wyss, M., and Koyanagi, R.Y., 1992, Isoseismal maps, macroseismic epicenters, and estimated magnitudes of historic earthquakes in the Hawaiian Islands: U.S. Geological Survey Bulletin 2006, 93 p.

\section{9, Koa'e Fault System}

Structure number 2609.

Comments: See figure 1 for the location map of the Koa'e fault system located in the southeastern part of the Island of Hawai'i.

Structure name Koa'e fault system.

Comments: The Koa'e fault system is located on Sheet 2 of 3 of the 1:100,000-scale geologic map compiled by Wolfe and Morris (1996), available in digital format from Trusdell and others (2006). Note that the fault system name "Kuae" on the Wolfe and Morris (1996) topographic base map is a misprint (D.A. Swanson, written commun., 2005).

Class of structure Not applicable.

Comments: None.

Synopsis The Koa'e fault system is located south of Kîlauea's caldera [2608a]. The Koa'e fault system, along with the east [2608b] and southwest [2608c] rift zones of Kīlauea Volcano, forms a zone of extension between the main Kîlauea edifice and the mobile south flank of Kîlauea Volcano (Duffield, 1975).

Date of compilation September 16, 2006.

Compiler and affiliation Eric C. Cannon; Roland Bürgmann, University of California Berkeley.

Province Hawaiian-Emperor island-seamount chain.

Geologic setting The Koa'e fault system is composed of a set of east-trending normal faults located south of Kîlauea's caldera that separate the main Kîlauea edifice to the north from Kîlauea's mobile flank to the south (Duffield, 1975). The Koa'e fault system strikes across the south flank from the east rift zone [2608b] to the southwest rift zone [2608c] of Kīlauea Volcano.

State Hawaii. 
County Hawaii.

$\mathbf{1}^{\circ} \mathbf{x} \mathbf{2}^{\circ}$ sheet Hawaii, HI, 1:250,000 scale, 1975.

Comments: The Koa'e fault system is located on the Ka' Desert, Kîlauea Crater, Makaopuhi Crater, and Volcano 7.5-minute topographic sheets.

\section{Reliability of location Good.}

Comments: Faults are shown at 1:100,000 scale by Wolfe and Morris (1996) and at 1:24,000 scale by Neal and Lockwood (2003).

Digital trace From the 1:100,000-scale geologic map compiled by Wolfe and Morris (1996), available in digital format from Trusdell and others (2006), generalized for this compilation.

Average strike (azimuth) N. $69^{\circ}$ E. $\pm 17^{\circ} ;+69^{\circ} \pm 17^{\circ}$.

Comments: Duffield (1975) states that most faults have a strike of N. $75^{\circ} \mathrm{E}$.

Length $(\mathrm{km}) 14.6$ (end to end); 58.1 (cumulative).

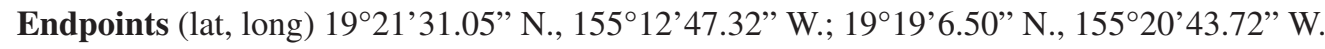

Sense of movement Normal.

Comments: From Duffield (1975), Wolfe and Morris (1996), and Neal and Lockwood (2003).

Dip Mostly vertical.

Comments: From Duffield (1975).

Dip direction N, S.

Comments: From Duffield (1975), Wolfe and Morris (1996), and Neal and Lockwood (2003).

Geomorphic expression Duffield (1975) states that the fault zone is composed of individual fractures less than $200 \mathrm{~m}$ long that form en echelon patterns. The east- to northeast-trending sinuous normal faults commonly form grabens with north-facing fault scarps being dominant (Duffield, 1975; Wolfe and Morris, 1996; Neal and Lockwood, 2003).

Age of faulted deposits Mapped faults cut lava flows with ages that range between approximately 200 and 1,500 yr B.P., and also cut a 1969 lava flow (Neal and Lockwood, 2003).

Timing of most recent paleoevent Historic (1975).

Comments: Associated with the earthquake of November 29, 1975, 04:47 am local time (Hawaiian Standard Time; Wyss and Koyanagi, 1992), M 7.2 mainshock, VII Modified Mercalli intensity (Tilling and others, 1976). Refer to the description of the November 29, 1975, Kalapana earthquake in this compilation for more details.

Recurrence interval Not reported.

Slip rate $>5 \mathrm{~mm} / \mathrm{yr}$.

Comments: Although Duffield (1975) did not give a slip rate for the fault system, he does mention that "the observed displacements in the Koa 'e fault system may have taken place in the last 500 years" (p. 11), and they possibly could have taken place as much as 650 yrs ago (D.A. Swanson, written commun., 2005). Duffield (1975) mentions that the average dilation across the Koa'e fault system is about $25 \mathrm{~m}$. The maximum dilation measured by other researchers is about $30 \mathrm{~m}$ (D.A. Swanson, written commun., 2005). Measured horizontal extension across the Koa'e fault system after the 1975 Kalapana earthquake was as much as $2 \mathrm{~m}$ (Tilling and others, 1976). Although variable through time, the data suggest that this dilation has probably been $>5 \mathrm{~mm} / \mathrm{yr}$ in the recent past.

\section{References}

Duffield, W.A., 1975, Structure and origin of the Koae fault system, Kilauea Volcano, Hawaii: U.S. Geological Survey Professional Paper 856, 12 p. 
Neal, C.A., and Lockwood, J.P., 2003, Geologic map of the summit region of Kîlauea Volcano, Hawaii: U.S. Geological Survey Geologic Investigations Series I-2759, 14 p., 1 sheet, scale 1:24,000.

Tilling, R.I., Koyanagi, R.Y., Lipman., P.W, Lockwood, J.P., Moore, J.G., and Swanson, D.A., 1976, Earthquake and related catastrophic events. Island of Hawaii, November 29, 1975-A preliminary report: U.S. Geological Survey Circular 740, 33 p.

Trusdell, F.A., Wolfe, E.W., and Morris, J., 2006, Digital database of the geologic map of the island of Hawai 'i: U.S. Geological Survey Data Series 144, supplement to Miscellaneous Investigations Series Map I-2524-A, 18 p., 1 sheet, scale 1:100,000.

Wolfe, E.W., and Morris, J., 1996, Geologic map of the island of Hawaii: U.S. Geological Survey Miscellaneous Investigations Series Map I-2524-A, 18 p., 3 sheets, scale 1:100,000.

Wyss, M., and Koyanagi, R.Y., 1992, Isoseismal maps, macroseismic epicenters, and estimated magnitudes of historic earthquakes in the Hawaiian Islands: U.S. Geological Survey Bulletin 2006, 93 p.

\section{0, Hilina Fault System}

\section{Structure number 2610.}

Comments: See figure 1 for the location map of the Hilina fault system, located in the southeastern part of the Island of Hawai'i. Figure 3 shows the fault sections of the Hilina fault system.

\section{Structure name Hilina fault system.}

Comments: The Hilina fault system consists of a set of roughly east-trending normal fault structures with moderate dips to the south and southeast. The term pali, used in several of the section names, is the Hawaiian work for "cliff" or "scarp." For example, the name Hilina Pali represents the geomorphic scarp of the Hilina fault. Another term used, $p u$ ' $u$ is the Hawaiian work for "hill."

Synopsis The first person to map the faults on the south flank of Kîlauea Volcano remains unknown, but Wood (1914) noted that subsidence occurred on the oceanward side of these structures related to the 1868 Great Ka' $\bar{u}$ earthquake, an estimated M8 earthquake (Wyss, 1988). Tilling and others (fig. 16, 1976) summarize faulting on the Hilina fault system associated with the November 29, 1975, M7.2 Kalapana earthquake. Lipman and others (1985) provide a comprehensive

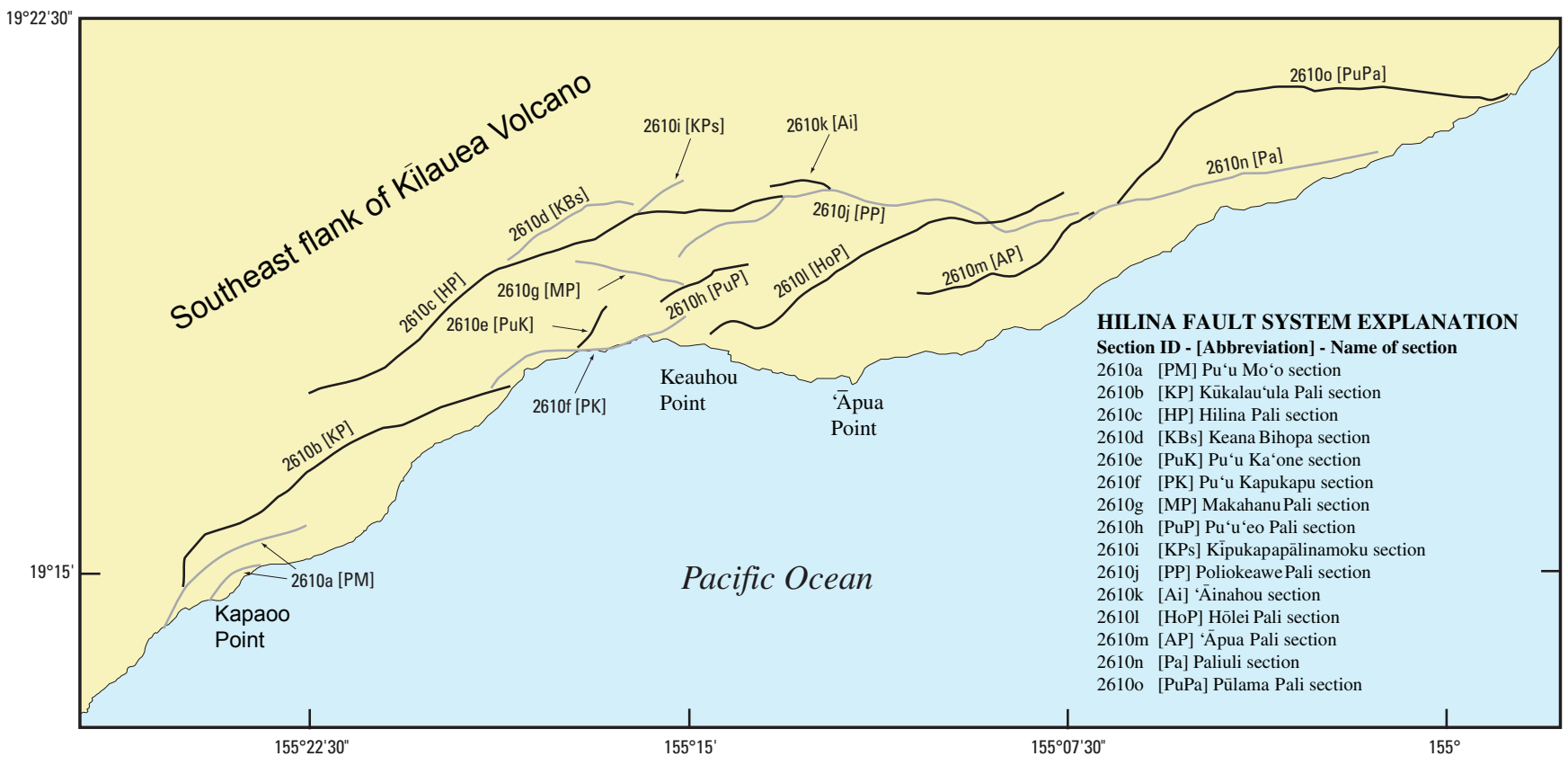

Figure 3. Location map of the Hilina fault system [2610] showing its 15 sections (from 2610a in the west to 2610o in the east). Figure modified from Wolfe and Morris (1996). Where multiple faults are located in close proximity on the map, the fault sctions are shown in black and gray to clarify their locations. 
report of the 1975 Kalapana earthquake. Refer to the description of the November 29, 1975, Kalapana earthquake in this compilation for more details. Kellogg and Chadwick (1987) record 1975 Kalapana earthquake fault offsets preserved in the Mauna Ulu pāhoehoe lava flows (1969-1974) for the central Hilina fault system. Riley and others (1999) estimate the depth of the Hilina fault system and recurrence interval for the 1975 Kalapana earthquake using paleomagnetic measurements of south flank lava flows. Expanding on the work of Kellogg and Chadwick (1987), Cannon and Bürgmann (2001) and Cannon and others (2001) present detailed fracture maps of central Hilina faults, estimate prehistoric fault offset rates and recurrence intervals for large $(\mathrm{M}>6)$ prehistoric south flank earthquakes, and provide evidence for a shallow rather than a deep-seated interpretation for some of the Hilina faults.

Faulting along the Hilina fault system is related to large $(M>6)$ earthquakes on the southern flank of Kīlauea Volcano. Delaney and others (1998) conclude that the small strains observed across the southern flank in the past several decades suggest that the Hilina faults remained inactive except for during the 1975 Kalapana earthquake. The landslide and tsunami potential of the Hilina fault system remains a great concern. Ma and others (1999) estimate that the tsunami created by the 1975 Kalapana earthquake displaced approximately $2.5 \mathrm{~km}^{3}$ of water. Along the coast and offshore of Killauea's south flank to the southeast, the Hilina fault system may represent the landslide headscarps to the submarine Hilina slump and Pāpa 'u sandrubble flow (fig. 1). Slumps and seafloor structures offshore of the Hilina fault system are interpreted as landslide blocks and debris (see Moore and others, 1989, 1995; Moore and Chadwick, 1995; Morgan and others, 2000, 2003). Significant coastal and submarine mass movements may have occurred within the past $100 \mathrm{ka}$. Geologic evidence demonstrates the existence of Quaternary deformation, but the fault system is associated with volcanic features that might not extend deeply enough to be a potential source of significant earthquakes.

Date of compilation September 16, 2006.

Compiler and affiliation Eric C. Cannon; Roland Bürgmann, University of California Berkeley.

Province Hawaiian-Emperor island-seamount chain.

Geologic setting The Hilina fault system is a normal fault system situated on the southern flank of Kỉlauea Volcano, Hawai'i. The present southern flank is being displaced to the southeast along a basal detachment by high-level rift zone intrusions and deep-seated gravitational spreading of the island. Between 1990 and 1996, south flank horizontal velocity rates determined from global positioning system (GPS) surveys indicate as much as $10 \mathrm{~cm} / \mathrm{yr}$ of lateral motion (Owen and others, 1995, 2000). This slightly northwest-dipping basal detachment at approximately $8-10 \mathrm{~km}$ depth represents the boundary between ocean lithosphere and the volcanic edifice. Pelagic sediment deposited on the seafloor prior to the formation of the volcanic edifice could be lubricating the basal detachment and promoting southeastward motion of the south flank. A comprehensive analysis of geodetic data for the 1975 Kalapana earthquake (Owen and Bürgmann, 2006) indicates that measured ground deformation on the south flank is best explained by a combination of faulting of the basal detachment, opening of the east rift zone [2608b] and southwest rift zone [2608c], a summit eruption and collapse of the summit magma chamber, and faulting on the Hilina fault system.

Sections of the Hilina fault system may vary in depth from shallow, arcuate normal faults to steeply dipping normal fault splays off the deep, basal detachment. Cannon and others (2001) conclude that Hōlei Pali [26101] and 'Āpua Pali [2610m] have fault dips of about $20^{\circ}$ at the surface and may flatten downward, reaching a 1-2 km depth at the coast and possibly intersecting the base of a 2- to 3-km-thick hyaloclastic layer offshore (Morgan and others, 2000). Riley and others (1999) interpret Hilina Pali [2610c] to be a cylindrical (curved) fault that extends to a depth of $5 \mathrm{~km}$. The Hilina fault system may also be a network of steeply-dipping normal fault splays off the 8- to 10-km-deep basal detachment (Lipman and others, 1985), with microseismicity possibly being localized at the intersection (Okubo and others, 1997).

\section{Number of sections 15 .}

Comments: The Hilina fault system is an approximately 50-km-long by $5-\mathrm{km}$-wide zone of primarily normal faults that extend east across the southeastern flank of Kīlauea Volcano. For this long fault system, we identify 15 fault sections on the basis of fault-scarp morphology measured on 7.5-minute topographic maps, continuity of expression, and evidence of apparent recent movement from cross-cutting relations of faults, fractures, and lava flows. The high number of sections for this fault system is largely the result of young movement, high rates of movement, associations with large historic earthquakes, and focused study by researchers. The 15 sections are Pu'u Mo'o [2610a], Kūkalau'ula Pali [2610b], Hilina Pali [2610c], Keana Bihopa [2610d], 
Pu’u Ka'one [2610e], Pu’u Kapukapu [2610f], Makahanu Pali [2610g], Pu’u’eo Pali [2610h], Kīpukapapālinamoku 2610i], Poliokeawe Pali [2610j], ‘Āinahou [2610k], Hōlei Pali [26101], ‘Āpua Pali [2610m], Paliuli [2610n], and Pūlama pali [2610o].

Average strike (azimuth) N. $69^{\circ}$ E. $\pm 22^{\circ} ;+69^{\circ} \pm 22^{\circ}$.

Length (km) 50.4 (end to end); 158.9 (cumulative).

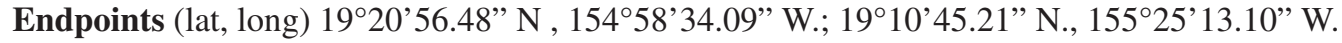

\section{References}

Cannon, E.C., and Bürgmann, R., 2001, Prehistoric fault offsets of the Hilina fault system, south flank of Kilauea Volcano, Hawaii: Journal of Geophysical Research, v. 106, no. B3, p. 4,207-4,219.

Cannon, E.C., Bürgmann, R., and Owen, S.E., 2001, Shallow normal faulting and block rotation associated with the 1975 Kalapana earthquake, Kilauea Volcano, Hawaii: Bulletin of the Seismological Society of America, v. 91, no. 6, p. 1,553-1,562.

Delaney, P.T., Denlinger, R.P., Lisowski, M., Miklius, A., Okubo, P.G., Okamura, A.T., and Sako, M.K., 1998, Volcanic spreading at Kilauea, 1976-1996: Journal of Geophysical Research, v. 103, no. B8, p. 18,003-18,023.

Kellogg, J.N., and Chadwick, W., 1987, Neotectonic study of the Hilina fault system, Kilauea, Hawaii: Geological Society of America Abstracts with Programs, v. 19, no. 6, p. 394.

Lipman, P.W., Lockwood, J.P., Okamura, R.T., Swanson, D.A., and Yamashita, K.M., 1985, Ground deformation associated with the 1975 magnitude-7.2 earthquake and resulting changes in activity of Kilauea Volcano, Hawaii: U.S. Geological Survey Professional Paper 1276, 45 p.

Ma, K.-F., Kanamori, H., and Satake, K., 1999, Mechanism of the 1975 Kalapana, Hawaii, earthquake inferred from tsunami data: Journal of Geophysical Research, v. 104, no. B6, p. 13,153-13,167.

Moore, J.G., Bryan, W.B., Beeson, M.H., and Normark, W.R., 1995, Giant blocks in the South Kona landslide, Hawaii: Geology, v. 23, no. 2, p. 125-128.

Moore, J.G., and Chadwick, W.W., Jr., 1995, Offshore geology of Mauna Loa and adjacent areas, Hawaii, in Rhodes, J.M., and Lockwood, J.P., eds., Mauna Loa revealed-Structure, composition, history, and hazards: American Geophysical Union Geophysical Monograph, v. 92, p. 21-44.

Moore, J.G., Clague, D.A., Holcomb, R.T., Lipman, P.W., Normark, W.R., and Torresan, M.E., 1989, Prodigious submarine landslides on the Hawaiian Ridge: Journal of Geophysical Research, v. 94, no. B12, p. 17,465-17,484.

Morgan, J.K., Moore, G.F., and Clague, D.A., 2003, Slope failure and volcanic spreading along the submarine south flank of Kilauea volcano, Hawaii: Journal of Geophysical Research, v. 108, no. B9, p. 2,415.

Morgan, J.K., Moore, G.F., Hill, D.J., and Leslie, S., 2000, Overthrusting and sediment accretion along Kīlauea's mobile south flank, Hawaii—Evidence from volcanic spreading from marine seismic reflection data: Geology, v. 28, no. 7, p. 667-670.

Okubo, P.G., Benz, H.M., and Chouet, B.A., 1997, Imaging the crustal magma sources beneath Mauna Loa and Kiluea volcanoes, Hawaii: Geology, v. 25, no. 10, p. 867-870.

Owen, S.E., and Bürgmann, R., 2006, An increment of volcano collapse-Kinematics of the 1975 Kalapana, Hawaii, earthquake: Journal of Volcanology and Geothermal Research, v. 104, no. 1, p. 163-185.

Owen, S., Segall, P., Freymueller, J., Miklius, A., Denlinger, R., Árnadottir, T., Sako, M., and Bürgmann, R., 1995, Rapid deformation of the south flank of Kilauea Volcano: Science, v. 267, no. 5205, p. 1,328-1,332.

Owen, S., Segall, P., Lisowski, M., Miklius, A., Denlinger, R., Freymueller, J., Árnadottir, T., and Sako, M., 2000, Rapid deformation of Kilauea Volcano-GPS measurements between 1990 and 1996: Journal of Geophysical Research, v. 105, no. B8, p. $18,983-18,998$.

Riley, C.M., Diehl, J.F., Kirschvink, J.L., and Ripperdan, R.L., 1999, Paleomagnetic constraints on fault motion in the Hilina fault system, south flank of Kilauea Volcano, Hawaii: Journal of Volcanology and Geothermal Research, v. 94, no. 1, p. 233-249.

Tilling, R.I., Koyanagi, R.Y., Lipman., P.W, Lockwood, J.P., Moore, J.G., and Swanson, D.A., 1976, Earthquake and related catastrophic events. Island of Hawaii, November 29, 1975-A preliminary report: U.S. Geological Survey Circular 740, 33 p. Wolfe, E.W., and Morris, J., 1996, Geologic map of the island of Hawaii: U.S. Geological Survey Miscellaneous Investigations Series Map I-2524-A, 18 p., 3 sheets, scale 1:100,000.

Wood, H.O., 1914, On the earthquakes of 1868 in Hawaii: Bulletin of the Seismological Society of America, v. 4, p. 169-203. Wyss, M., 1988, A proposed source model for the Great Kau, Hawaii, earthquake of 1868: Bulletin of the Seismological Society of America, v. 78, no. 4, p. 1,450-1,462. 


\section{0a, Pu'u Mo`o Section, Hilina Fault System}

Section number 2610a.

Section name $\mathrm{Pu}$ 'u Mo'o section.

Comments: Informally named by the senior author, $\mathrm{Pu}$ 'u Mo'o comprises two traces: a southern trace near $\mathrm{Pu}$ ' $\mathrm{u} \mathrm{Mo}$ 'o, and a second trace to the north that has a western termination approximately $1 \mathrm{~km}$ southeast of Mahuka Bay. Pu'u Mo'o is located in the western portion of the Hilina fault system.

Class of structure Not applicable.

Comments: None.

State Hawaii.

County Hawaii.

$\mathbf{1}^{\circ} \mathbf{x}{ }^{\circ}$ sheet Hawaii, HI, 1:250,000 scale, 1975.

Comments: Located on the Pāhala 7.5-minute topographic sheet.

\section{Reliability of location Poor.}

Comments: The fault trace is identified on the 1:100,000-scale geologic map as concealed (Wolfe and Morris, 1996). The fault trace is not well defined on the 1:24,000-scale Pāhala topographic map.

Digital trace From the 1:100,000-scale geologic map compiled by Wolfe and Morris (1996), available in digital format from Trusdell and others (2006), generalized for this compilation.

Average strike (azimuth) N. $56^{\circ}$ E. $\pm 19^{\circ} ;+56^{\circ} \pm 19^{\circ}$.

Length (km) 6.1 (end to end); 8.9 (cumulative).

Comments: The northern trace is about $6 \mathrm{~km}$ long, and the southern trace is about $2 \mathrm{~km}$ long.

Endpoints (lat, long) $19^{\circ} 12^{\prime} 41.99^{\prime \prime}$ N., $155^{\circ} 22^{\prime} 22.57^{\prime \prime}$ W.; $19^{\circ} 10^{\prime} 45.21^{\prime \prime}$ N., $155^{\circ} 25^{\prime} 13.10^{\prime \prime}$ W.

Sense of movement Normal.

Comments: From Wolfe and Morris (1996).

Dip Not reported.

Dip direction SE.

Comments: As shown by Wolfe and Morris (1996).

Geomorphic expression The lava-draped normal fault scarps produce geomorphic scarps.

Age of faulted deposits The southern and northern faults are buried by unfaulted surface lava flows as old as 400-750 yr B.P. and 1,500-3,000 yr B.P., respectively (Wolfe and Morris, 1996). See Holcomb (1987) for more details of ages of individual lava flows.

Timing of most recent paleoevent Holocene and latest Pleistocene $(<15 \mathrm{ka})$.

Comments: Not reported but probably late Holocene. Tilling and others (1976) do not identify faulting resulting from the 1975 Kalapana earthquake.

Recurrence interval Not reported.

Slip rate Unknown; probably $1-5 \mathrm{~mm} / \mathrm{yr}$.

Comments: Not reported. This estimate is based on the proximity to Kükalau'ula Pali [2610b], which has an estimated slip rate of $1-5 \mathrm{~mm} / \mathrm{yr}$ based on similarity to 'Āpua Pali [2610m]. 


\section{References}

Holcomb, R.T., 1987, Eruptive history and long-term behavior of Kilauea Volcano, in Decker, R.W., Wright, T.L., and Stauffer, P.H., eds., Volcanism in Hawaii: U.S. Geological Survey Professional Paper 1350, v. 1, p. 261-350.

Tilling, R.I., Koyanagi, R.Y., Lipman., P.W, Lockwood, J.P., Moore, J.G., and Swanson, D.A., 1976, Earthquake and related catastrophic events. Island of Hawaii, November 29, 1975-A preliminary report: U.S. Geological Survey Circular 740, 33 p.

Trusdell, F.A., Wolfe, E.W., and Morris, J., 2006, Digital database of the geologic map of the island of Hawai 'i: U.S. Geological Survey Data Series 144, supplement to Miscellaneous Investigations Series Map I-2524-A, 18 p., 1 sheet, scale 1:100,000.

Wolfe, E.W., and Morris, J., 1996, Geologic map of the island of Hawaii: U.S. Geological Survey Miscellaneous Investigations Series Map I-2524-A, 18 p., 3 sheets, scale 1:100,000.

\section{0b, Kūkalau'ula Pali Section, Hilina Fault System}

Section number $2610 b$.

Section name Kūkalau'ula Pali section.

Comments: The Kūkalau 'ula Pali section is located in the western portion of the Hilina fault system.

Class of structure Not applicable.

Comments: None.

State Hawaii.

County Hawaii.

$\mathbf{1}^{\circ} \mathbf{x} \mathbf{2}^{\circ}$ sheet Hawaii, HI, 1:250,000 scale, 1975.

Comments: Located on the Ka' ū Desert, Nāli 'ikakani Point, and Pāhala 7.5-minute topographic sheets.

\section{Reliability of location Good.}

Comments: The fault trace is identified on the 1:100,000-scale geologic map (Wolfe and Morris, 1996), and the geomorphic scarp is well defined on the 1:24,000-scale Ka' ${ }^{\prime} \bar{u}$ Desert and Nāli'ikakani Point topographic maps. The western part of the fault trace is inferred by Wolfe and Morris (1996) and is not well defined on the 1:24,000-scale Pāhala topographic map.

Digital trace From the 1:100,000-scale geologic map compiled by Wolfe and Morris (1996), available in digital format from Trusdell and others (2006), generalized for this compilation.

Average strike (azimuth) N. $59^{\circ}$ E. $\pm 26^{\circ} ;+59^{\circ} \pm 26^{\circ}$.

Length $(\mathrm{km}) 13.4$ (end to end); 18.0 (cumulative).

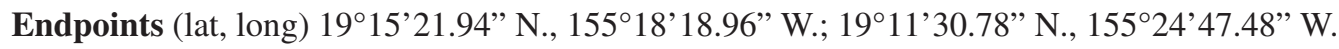

Sense of movement Normal.

Comments: Normal faulting occurred in the 1975 Kalapana earthquake (Tilling and others, fig. 16, 1976; Lipman and others, 1985).

Dip Not reported.

\section{Dip direction SE.}

Comments: Southeast-side down (Tilling and others, fig. 16, 1976; Wolfe and Morris, 1996).

Geomorphic expression The maximum geomorphic scarp height is about $90 \mathrm{~m}$. The scarp has a slope angle of about $30^{\circ}$.

Age of faulted deposits Faults cut surface lava flows as young as $200-400 \mathrm{yr}$ B.P., and lava flows as old as 750-1,500 yr B.P. conceal some fault traces (Wolfe and Morris, 1996). See Holcomb (1987) for details of ages of individual lava flows. 
Timing of most recent paleoevent Historic (1975).

Comments: For the 1975 Kalapana earthquake, Tilling and others (fig. 16, 1976) note vertical displacements of $>1.0 \mathrm{~m}$ at the southern end and $>1.0 \mathrm{~m}$ at the northern end of two faults that represent the K kalau'ula Pali section.

Recurrence interval Not reported.

Slip rate Unknown; probably $1-5 \mathrm{~mm} / \mathrm{yr}$.

Comments: Not reported. The estimated slip rate of 1-5 mm/yr is based on faults cutting late Holocene lava flows and on a large scarp height similar in scale to 'Āpua Pali [2610m].

\section{References}

Holcomb, R.T., 1987, Eruptive history and long-term behavior of Kilauea Volcano, in Decker, R.W., Wright, T.L., and Stauffer, P.H., eds., Volcanism in Hawaii: U.S. Geological Survey Professional Paper 1350, v. 1, p. $261-350$.

Lipman, P.W., Lockwood, J.P., Okamura, R.T., Swanson, D.A., and Yamashita, K.M., 1985, Ground deformation associated with the 1975 magnitude-7.2 earthquake and resulting changes in activity of Kilauea Volcano, Hawaii: U.S. Geological Survey Professional Paper 1276, 45 p.

Tilling, R.I., Koyanagi, R.Y., Lipman., P.W, Lockwood, J.P., Moore, J.G., and Swanson, D.A., 1976, Earthquake and related catastrophic events. Island of Hawaii, November 29, 1975-A preliminary report: U.S. Geological Survey Circular 740, 33 p.

Trusdell, F.A., Wolfe, E.W., and Morris, J., 2006, Digital database of the geologic map of the island of Hawai 'i: U.S. Geological Survey Data Series 144, supplement to Miscellaneous Investigations Series Map I-2524-A, 18 p., 1 sheet, scale 1:100,000.

Wolfe, E.W., and Morris, J., 1996, Geologic map of the island of Hawaii: U.S. Geological Survey Miscellaneous Investigations Series Map I-2524-A, 18 p., 3 sheets, scale 1:100,000.

\section{0c, Hilina Pali Section, Hilina Fault System}

Section number 2610c.

Section name Hilina Pali section.

Comments: The Hilina Pali section is located in the western and central portion of the Hilina fault system.

Class of structure Not applicable.

Comments: None.

State Hawaii.

County Hawaii.

$\mathbf{1}^{\circ} \mathbf{x}{ }^{\circ}$ sheet Hawaii, HI, 1:250,000 scale, 1975.

Comments: Located on the Ka' $\bar{u}$ Desert and Makaopuhi Crater 7.5-minute topographic sheets.

Reliability of location Good.

Comments: The fault traces are surficial and concealed on the 1:100,000-scale geologic map (Wolfe and Morris, 1996). The geomorphic fault scarp is well located on the 1:24,000-scale Ka' $\bar{u}$ Desert and Makaopuhi Crater topographic sheets.

Digital trace From the 1:100,000-scale geologic map compiled by Wolfe and Morris (1996), available in digital format from Trusdell and others (2006), generalized for this compilation.

Average strike (azimuth) N. $67^{\circ}$ E. $\pm 17^{\circ} ;+67^{\circ} \pm 17^{\circ}$.

Length $(\mathrm{km}) 17.9$ (end to end); 28.4 (cumulative).

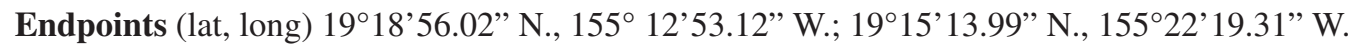


Sense of movement Normal.

Comments: From Wolfe and Morris (1996). Normal faulting occurred in the 1975 Kalapana earthquake (Tilling and others, fig. 16, 1976; Lipman and others, 1985).

Dip Not reported.

Dip direction S to SE.

Comments: As shown by Tilling and others (1976) and Wolfe and Morris (1996), south to southeast side down.

Geomorphic expression The maximum geomorphic scarp height is about $490 \mathrm{~m}$ with a slope of about $28^{\circ}$.

Age of faulted deposits Faults cut surface lava flows that range in age from 200-400 yr B.P. to 1,500-3,000 yr B.P.

(Wolfe and Morris, 1996). See Holcomb (1987) for details of ages of lava flows.

Timing of most recent paleoevent Historic (1975).

Comments: Tilling and others (fig. 16, 1976) note that $1.5 \mathrm{~m}$ of vertical subsidence was observed on the Hilina Pali for the 1975 Kalapana earthquake. Riley and others (1999) suggest that the Hilina Pali fault is responsible for block rotation of the Pu'u Kapukapu block [2610f]. The Hilina Pali fault may be cylindrical (curved) to an approximately 5-km depth based on paleomagnetic measurements of rotated lava flows (Riley and others, 1999).

Recurrence interval 200 years.

Comments: Riley and others (1999) based a 200-yr recurrence interval on $710 \mathrm{~m}$ of vertical offset in the Puna Basalt that occurred over the past $38.5 \mathrm{ka}$. Since the 1975 Kalapana earthquake produced $3.5 \mathrm{~m}$ of subsidence, approximately one Kalapana-sized earthquake every 200 years could explain the $710 \mathrm{~m}$ of vertical displacement.

Slip rate $>5 \mathrm{~mm} / \mathrm{yr}$.

Comments: The vertical slip rate of $20 \mathrm{~mm} / \mathrm{yr}$ reported by Riley and others (1999) is based on $710 \mathrm{~m}$ of vertical fault offset over the past $38.5 \mathrm{ka}$.

\section{References}

Holcomb, R.T., 1987, Eruptive history and long-term behavior of Kilauea Volcano, in Decker, R.W., Wright, T.L., and Stauffer, P.H., eds., Volcanism in Hawaii: U.S. Geological Survey Professional Paper 1350, v. 1, p. 261-350.

Lipman, P.W., Lockwood, J.P., Okamura, R.T., Swanson, D.A., and Yamashita, K.M., 1985, Ground deformation associated with the 1975 magnitude-7.2 earthquake and resulting changes in activity of Kilauea Volcano, Hawaii: U.S. Geological Survey Professional Paper 1276, 45 p.

Riley, C.M., Diehl, J.F., Kirschvink, J.L., and Ripperdan, R.L., 1999, Paleomagnetic constraints on fault motion in the Hilina fault system, south flank of Kilauea Volcano, Hawaii, Journal of Volcanology and Geothermal Research, v. 94, no. 1, p. 233-249.

Tilling, R.I., Koyanagi, R.Y., Lipman., P.W, Lockwood, J.P., Moore, J.G., and Swanson, D.A., 1976, Earthquake and related catastrophic events. Island of Hawaii, November 29, 1975-A preliminary report: U.S. Geological Survey Circular 740, 33 p.

Trusdell, F.A., Wolfe, E.W., and Morris, J., 2006, Digital database of the geologic map of the island of Hawai'i: U.S. Geological Survey Data Series 144, supplement to Miscellaneous Investigations Series Map I-2524-A, 18 p., 1 sheet, scale $1: 100,000$.

Wolfe, E.W., and Morris, J., 1996, Geologic map of the island of Hawaii: U.S. Geological Survey Miscellaneous Investigations Series Map I-2524-A, 18 p., 3 sheets, scale 1:100,000.

\section{0d, Keana Bihopa Section, Hilina Fault System}

Section number $2610 d$.

Section name Keana Bihopa.

Comments: The Keana Bihopa section is a fault splay off of the adjacent Hilina Pali section [2610c] and is located in the western portion of the Hilina fault system. 
Class of structure Not applicable.

Comments: None.

State Hawaii.

County Hawaii.

$\mathbf{1}^{\circ} \mathbf{x}{ }^{\circ}$ sheet Hawaii, HI, 1:250,000 scale, 1975.

Comments: Located on the Ka' $\overline{\mathrm{u}}$ Desert 7.5-minute topographic sheet.

Reliability of location Good.

Comments: Both surficial and concealed fault traces are shown on the 1:100,000-scale geologic map (Wolfe and Morris, 1996), and the geomorphic fault scarp is present on the 1:24,000-scale Ka' $\bar{u}$ Desert topographic sheet.

Digital trace From the 1:100,000-scale map compiled by Wolfe and Morris (1996), available in digital format from Trusdell and others (2006), generalized for this compilation.

Average strike (azimuth) N. $55^{\circ}$ E. $\pm 21^{\circ} ;+55^{\circ} \pm 21^{\circ}$.

Length (km) 4.8 (end to end); 6.4 (cumulative).

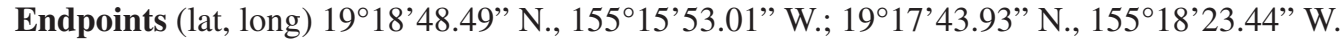

Sense of movement Normal.

Comments: From Wolfe and Morris (1996).

Dip Not reported.

Dip direction SE.

Comments: From Wolfe and Morris (1996).

Geomorphic expression The maximum geomorphic scarp height is approximately $60 \mathrm{~m}$ with a slope of about $40^{\circ}$.

Age of faulted deposits Faults cut surface lava flows that have ages of 750-1,500 yr B.P. and 1,500-3,000 yr B.P. Lava flows that have an age of 400-750 yr B.P. conceal some fault traces (Wolfe and Morris, 1996). See Holcomb (1987) for more details of ages of lava flows.

Timing of most recent paleoevent Historic (1975).

Comments: Tilling and others (fig. 16, 1976) observed displacement after the 1975 Kalapana earthquake but do not provide a displacement estimate.

Recurrence interval Not reported.

Slip rate Unknown; probably $1-5 \mathrm{~mm} / \mathrm{yr}$.

Comments: Tilling and others (fig. 16, 1976) note that vertical subsidence was observed on the Keana Bihopa splay of Hilina Pali after the 1975 Kalapana earthquake but do not give a vertical offset estimate. The estimated slip rate of 1-5 mm/yr is based on faults cutting late Holocene lava flows and on a large scarp height similar in scale to 'Āpua Pali [2610m].

\section{References}

Holcomb, R.T., 1987, Eruptive history and long-term behavior of Kilauea Volcano, in Decker, R.W., Wright, T.L., and Stauffer, P.H., eds., Volcanism in Hawaii: U.S. Geological Survey Professional Paper 1350, v. 1, p. $261-350$.

Tilling, R.I., Koyanagi, R.Y., Lipman., P.W, Lockwood, J.P., Moore, J.G., and Swanson, D.A., 1976, Earthquake and related catastrophic events. Island of Hawaii, November 29, 1975-A preliminary report: U.S. Geological Survey Circular 740, 33 p. 
Trusdell, F.A., Wolfe, E.W., and Morris, J., 2006, Digital database of the geologic map of the island of Hawai'i: U.S. Geological Survey Data Series 144, supplement to Miscellaneous Investigations Series Map I-2524-A, 18 p., 1 sheet, scale $1: 100,000$.

Wolfe, E.W., and Morris, J., 1996, Geologic map of the island of Hawaii: U.S. Geological Survey Miscellaneous Investigations Series Map I-2524-A, 18 p., 3 sheets, scale 1:100,000.

\section{0e, Pu'u Ka'one Section, Hilina Fault System}

Section number 2610e.

Section name $\mathrm{Pu}$ 'u $\mathrm{Ka}$ 'one section.

Comments: The Pu'u Ka'one section is located in the western portion of the Hilina fault system. Pu'u Kapukapu [2610f] forms a normal fault splay off of $\mathrm{Pu}$ 'u Ka'one.

Class of structure Not applicable.

Comments: None.

State Hawaii.

County Hawaii.

$\mathbf{1}^{\circ} \mathbf{x} \mathbf{2}^{\circ}$ sheet Hawaii, HI, 1:250,000 scale, 1975.

Comments: Located on the Ka' $\bar{u}$ Desert 7.5-minute topographic sheet.

Reliability of location Good.

Comments: Both surficial and concealed fault traces are shown on the 1:100,000-scale geologic map (Wolfe and Morris, 1996), and the geomorphic fault scarp is present on the 1:24,000-scale Ka' $\bar{u}$ Desert topographic map.

Digital trace From the 1:100,000-scale geologic map compiled by Wolfe and Morris (1996), available in digital format from Trusdell and others (2006), generalized for this compilation.

Average strike (azimuth) N. $54^{\circ}$ E. $\pm 22^{\circ} ;+54^{\circ} \pm 22^{\circ}$.

Length $(\mathrm{km}) 4.9$ (end to end); 4.8 (cumulative).

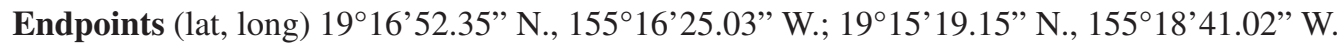

Sense of movement Normal.

Comments: Normal faulting, southeast side down. A vertical offset of $1.5 \mathrm{~m}$ was observed after the 1975 Kalapana earthquake (Tilling and others, fig. 19, 1976; Lipman and others, 1985).

Dip Not reported.

Dip direction SE.

Comments: From Tilling and others (1976), Wolfe and Morris (1996).

Geomorphic expression The maximum geomorphic scarp height is approximately $90 \mathrm{~m}$ with a scarp slope of about $37^{\circ}$.

Age of faulted deposits The fault cuts Kahuku Basalt that has an estimated radiocarbon age of $>31$ ka. (Wolfe and Morris, 1996). See Holcomb (1987) for details of ages of individual lava flows.

Timing of most recent paleoevent Historic (1975).

Comments: A vertical offset of $1.5 \mathrm{~m}$ was reported for the 1975 Kalapana earthquake (Tilling and others, fig. 19, 1976).

Recurrence interval Not reported. 
Slip rate Unknown; probably $1-5 \mathrm{~mm} / \mathrm{yr}$.

Comments: Not reported. The estimated slip rate of $1-5 \mathrm{~mm} / \mathrm{yr}$ is based on faults cutting possibly late Pleistocene lava flows and on a large scarp height similar in scale to 'Āpua Pali [2610m].

\section{References}

Holcomb, R.T., 1987, Eruptive history and long-term behavior of Kilauea Volcano, in Decker, R.W., Wright, T.L., and Stauffer, P.H., eds., Volcanism in Hawaii: U.S. Geological Survey Professional Paper 1350, v. 1, p. 261-350.

Lipman, P.W., Lockwood, J.P., Okamura, R.T., Swanson, D.A., and Yamashita, K.M., 1985, Ground deformation associated with the 1975 magnitude-7.2 earthquake and resulting changes in activity of Kilauea Volcano, Hawaii: U.S. Geological Survey Professional Paper 1276, 45 p.

Tilling, R.I., Koyanagi, R.Y., Lipman., P.W, Lockwood, J.P., Moore, J.G., and Swanson, D.A., 1976, Earthquake and related catastrophic events. Island of Hawaii, November 29, 1975-A preliminary report: U.S. Geological Survey Circular $740,33 \mathrm{p}$.

Trusdell, F.A., Wolfe, E.W., and Morris, J., 2006, Digital database of the geologic map of the island of Hawai' 1 i: U.S. Geological Survey Data Series 144, supplement to Miscellaneous Investigations Series Map I-2524-A, 18 p., 1 sheet, scale 1:100,000.

Wolfe, E.W., and Morris, J., 1996, Geologic map of the island of Hawaii: U.S. Geological Survey Miscellaneous Investigations Series Map I-2524-A, 18 p., 3 sheets, scale 1:100,000.

\section{0f, Pu'u Kapukapu Section, Hilina Fault System}

Section number $2610 f$.

Section name $\mathrm{Pu}$ 'u Kapukapu section.

Comments: Pu 'u Kapukapu forms a normal fault splay off of Pu 'u Ka'one [2610e]. The Pu 'u Kapukapu section is located in the western portion of the Hilina fault system. The term kapukapu is the Hawaiian word for "forbidden" or "sacred."

Class of structure Not applicable.

Comments: None.

State Hawaii.

County Hawaii.

$\mathbf{1}^{\circ} \mathbf{x} 2^{\circ}$ sheet Hawaii, HI, 1:250,000 scale, 1975.

Comments: Located on the Ka' $\bar{u}$ Desert and Makaopuhi Crater 7.5-minute topographic sheet.

\section{Reliability of location Good.}

Comments: Both surficial and concealed fault traces are shown on the 1:100,000-scale geologic map (Wolfe and Morris, 1996), and the geomorphic fault scarp is present on the 1:24,000-scale Ka' $\bar{u}$ Desert and Makaopuhi Crater topographic maps.

Digital trace From the 1:100,000-scale geologic map compiled by Wolfe and Morris (1996), available in digital format from Trusdell and others (2006), generalized for this compilation.

Average strike (azimuth) N. $67^{\circ}$ E. $\pm 13^{\circ} ;+67^{\circ} \pm 13^{\circ}$.

Length $(\mathrm{km}) 1.4$ (end to end); 2.1 (cumulative).

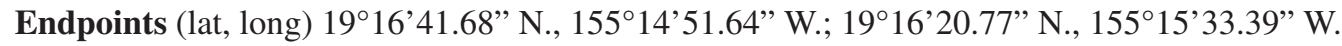

Sense of movement Normal.

Comments: From Wolfe and Morris (1996).

Dip Not reported. 


\section{Dip direction SE.}

Comments: From Wolfe and Morris (1996).

Geomorphic expression The maximum geomorphic scarp height is approximately $320 \mathrm{~m}$ with a slope of about $37^{\circ}$.

Age of faulted deposits The fault cuts the Kahuku Basalt that has an estimated radiocarbon age of $>31 \mathrm{ka}$. (Wolfe and Morris, 1996). See Holcomb (1987) for details of ages of individual lava flows.

Timing of most recent paleoevent Holocene and latest Pleistocene $(<15 \mathrm{ka})$.

Comments: Not reported but probably late Holocene, based on proximity to Pu 'u Ka'one [2610e], which had displacement from the 1975 Kalapana earthquake. A rockfall triggered by the 1975 Kalapana earthquake was reported on Pu 'u Kapukapu (Tilling and others, 1976). Since part of Pu'u Kapukapu's scarp descends steeply to the shoreline, part of the fault trace may be underwater and inaccessible offshore.

Recurrence interval Not reported.

Slip rate Unknown; probably $>5 \mathrm{~mm} / \mathrm{yr}$.

Comments: Not reported. The estimated slip rate of $>5 \mathrm{~mm} / \mathrm{yr}$ is based on faults cutting possibly late Pleistocene lava flows and on a large scarp height similar in scale to Hōlei Pali [26101].

\section{References}

Holcomb, R.T., 1987, Eruptive history and long-term behavior of Kilauea Volcano, in Decker, R.W., Wright, T.L., and Stauffer, P.H., eds., Volcanism in Hawaii: U.S. Geological Survey Professional Paper 1350, v. 1, p. 261-350.

Tilling, R.I., Koyanagi, R.Y., Lipman., P.W, Lockwood, J.P., Moore, J.G., and Swanson, D.A., 1976, Earthquake and related catastrophic events. Island of Hawaii, November 29, 1975-A preliminary report: U.S. Geological Survey Circular $740,33 \mathrm{p}$.

Trusdell, F.A., Wolfe, E.W., and Morris, J., 2006, Digital database of the geologic map of the island of Hawai 'i: U.S. Geological Survey Data Series 144. supplement to Miscellaneous Investigations Series Map I-2524-A, 18 p., 1 sheet, scale $1: 100,000$.

Wolfe, E.W., and Morris, J., 1996, Geologic map of the island of Hawaii: U.S. Geological Survey Miscellaneous Investigations Series Map I-2524-A, 18 p., 3 sheets, scale 1:100,000.

\section{0g, Makahanu Pali Section, Hilina Fault System}

Section number $2610 \mathrm{~g}$.

Section name Makahanu Pali section.

Comments: The Makahanu Pali section exists in the west-central portion of the Hilina fault system. Makahanu Pali connects to the Pu'u'eo Pali section [2610h] and may represent a normal-fault splay off Hilina Pali [2610c] to the west.

Class of structure Not applicable.

Comments: None.

State Hawaii.

County Hawaii.

$\mathbf{1}^{\circ} \mathbf{x} \mathbf{2}^{\circ}$ sheet Hawaii, HI, 1:250,000 scale, 1975.

Comments: Located on the Ka' $\bar{u}$ Desert 7.5-minute topographic sheet.

Reliability of location Good.

Comments: Both surficial and concealed fault traces are shown on the 1:100,000-scale geologic map (Wolfe and Morris, 1996), and the geomorphic fault scarp is present on the 1:24,000-scale Ka' $\bar{u}$ Desert topographic map.

Digital trace From the 1:100,000-scale geologic map of Wolfe and Morris (1996), available in digital format from Trusdell and others (2006), generalized for this compilation. 
Average strike (azimuth) N. $78^{\circ}$ W. $\pm 7^{\circ} ;-78^{\circ} \pm 7^{\circ}$.

Length (km) 4.0 (end to end); 4.0 (cumulative).

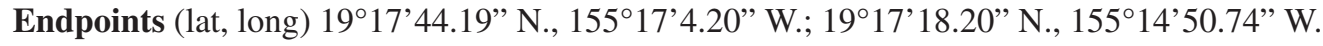

Sense of movement Normal.

Comments: From Wolfe and Morris (1996).

Dip Not reported.

Dip direction SW.

Comments: From Wolfe and Morris (1996).

Geomorphic expression The maximum geomorphic scarp height is approximately $80 \mathrm{~m}$ with a scarp slope of about $20^{\circ}$.

Age of faulted deposits Faults cut surface lava flows that have an age of 750-1,500 yr B.P. (Wolfe and Morris, 1996). See Holcomb (1987) for details of ages of individual lava flows.

Timing of most recent paleoevent Holocene and latest Pleistocene $(<15 \mathrm{ka})$.

Comments: Not reported but estimated as late Holocene based on ages of lava flows cut by the fault. Tilling and others (1976) do not report evidence of faulting from the 1975 Kalapana earthquake.

Recurrence interval Not reported.

Slip rate Unknown; probably $1-5 \mathrm{~mm} / \mathrm{yr}$.

Comments: Not reported. The estimated slip rate of $1-5 \mathrm{~mm} / \mathrm{yr}$ is based on faults cutting late Holocene lava flows and on a large scarp height similar in scale to 'Āpua Pali [2610m].

\section{References}

Holcomb, R.T., 1987, Eruptive history and long-term behavior of Kilauea Volcano, in Decker, R.W., Wright, T.L., and Stauffer, P.H., eds., Volcanism in Hawaii: U.S. Geological Survey Professional Paper 1350, v. 1, p. 261-350.

Tilling, R.I., Koyanagi, R.Y., Lipman., P.W, Lockwood, J.P., Moore, J.G., and Swanson, D.A., 1976, Earthquake and related catastrophic events. Island of Hawaii, November 29, 1975-A preliminary report: U.S. Geological Survey Circular 740,33 p.

Trusdell, F.A., Wolfe, E.W., and Morris, J., 2006, Digital database of the geologic map of the island of Hawai'i: U.S. Geological Survey Data Series 144, supplement to Miscellaneous Investigations Series Map I-2524-A, 18 p., 1 sheet, scale 1:100,000.

Wolfe, E.W., and Morris, J., 1996, Geologic map of the island of Hawaii: U.S. Geological Survey Miscellaneous Investigations Series Map I-2524-A, 18 p., 3 sheets, scale 1:100,000.

\section{0h, Pu'u'eo Pali Section, Hilina Fault System}

Section number $2610 \mathrm{~h}$.

Section name $\mathrm{Pu}$ 'u'eo Pali section.

Comments: The Pu'u'eo Pali section exists in the west-central portion of the Hilina fault system. The Makahanu Pali section [2610g] forms a normal fault splay off of the $\mathrm{Pu}$ 'u'eo Pali section.

Class of structure Not applicable.

Comments: None.

State Hawaii.

County Hawaii. 
$\mathbf{1}^{\circ} \mathbf{x} \mathbf{2}^{\circ}$ sheet Hawaii, HI, 1:250,000 scale, 1975.

Comments: Located on the Ka' ${ }^{‘} \bar{u}$ Desert and Makaopuhi Crater 7.5-minute topographic sheets.

\section{Reliability of location Good.}

Comments: Both surficial and concealed fault traces are shown on the 1:100,000-scale geologic map (Wolfe and Morris, 1996), and the geomorphic fault scarp is visible on the 1:24,000-scale Ka'ū Desert and Makaopuhi Crater topographic maps.

Digital trace From the 1:100,000-scale geologic map compiled by Wolfe and Morris (1996), available in digital format from Trusdell and others (2006), generalized for this compilation.

Average strike (azimuth) N. $67^{\circ}$ E. $\pm 14^{\circ} ;+67^{\circ} \pm 14^{\circ}$.

Length $(\mathrm{km}) 4.2$ (end to end); 6.2 (cumulative).

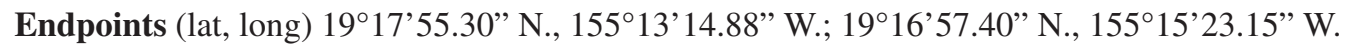

\section{Sense of movement Normal.}

Comments: From Wolfe and Morris (1996).

Dip $63^{\circ}$.

Comments: Fieldwork conducted by the senior author in 1999 found one piercing point on Pu'u'eo Pali in a 750-1,500 yr B.P. age lava flow with $163 \mathrm{~cm}$ total offset, plunging $63^{\circ}$ toward an azimuth of S. $12^{\circ}$ E. (E.C. Cannon, unpub. field data, 1999).

\section{Dip direction SE.}

Comments: From Wolfe and Morris (1996).

Geomorphic expression The maximum geomorphic scarp height is approximately $150 \mathrm{~m}$ with a scarp slope of about $30^{\circ}$.

Age of faulted deposits Faults cut surface lava flows that have an age of 750-1,500 yr B.P. (Wolfe and Morris, 1996). See Holcomb (1987) for details of ages of individual lava flows.

Timing of most recent paleoevent Holocene and latest Pleistocene $(<15 \mathrm{ka})$.

Comments: Not reported but estimated to be late Holocene based on ages of lava flows cut by the fault. Tilling and others (1976) do not identify faulting that resulted from the 1975 Kalapana earthquake.

\section{Recurrence interval Not reported.}

Slip rate Unknown; perhaps $1-5 \mathrm{~mm} / \mathrm{yr}$.

Comments: Not reported. The estimated slip rate of $1-5 \mathrm{~mm} / \mathrm{yr}$ is based on faults cutting late Holocene lava flows and on a large scarp height similar in scale to Hōlei Pali [26101].

\section{References}

Holcomb, R.T., 1987, Eruptive history and long-term behavior of Kilauea Volcano, in Decker, R.W., Wright, T.L., and Stauffer, P.H., eds., Volcanism in Hawaii: U.S. Geological Survey Professional Paper 1350, v. 1, p. 261-350.

Tilling, R.I., Koyanagi, R.Y., Lipman., P.W, Lockwood, J.P., Moore, J.G., and Swanson, D.A., 1976, Earthquake and related catastrophic events. Island of Hawaii, November 29, 1975-A preliminary report: U.S. Geological Survey Circular 740, 33 p.

Trusdell, F.A., Wolfe, E.W., and Morris, J., 2006, Digital database of the geologic map of the island of Hawai'i: U.S. Geological Survey Data Series 144, supplement to Miscellaneous Investigations Series Map I-2524-A, 18 p., 1 sheet, scale $1: 100,000$.

Wolfe, E.W., and Morris, J., 1996, Geologic map of the island of Hawaii: U.S. Geological Survey Miscellaneous Investigations Series Map I-2524-A, 18 p., 3 sheets, scale 1:100,000. 


\section{0i, Kīpukapapālinamoku Section, Hilina Fault System}

Section number 2610 i.

Section name Kīpukapapālinamoku.

Comments: The Kīpukapapālinamoku section is a normal fault splay off the adjacent Hilina Pali section [2610c] and is located along the west-central portion of the Hilina fault system.

Class of structure Not applicable.

Comments: None.

State Hawaii.

County Hawaii.

$\mathbf{1}^{\circ} \mathbf{x} 2^{\circ}$ sheet Hawaii, HI, 1:250,000 scale, 1975.

Comments: Located on the Ka' ${ }^{\prime} \overline{\mathrm{D}}$ Desert and Makaopuhi Crater 7.5-minute topographic sheets.

Reliability of location Good.

Comments: Both surficial and concealed fault traces are shown on the 1:100,000-scale geologic map (Wolfe and Morris, 1996), and the geomorphic fault scarp is visible on the 1:24,000-scale Ka'ū Desert and Makaopuhi Crater topographic maps.

Digital trace From the 1:100,000-scale geologic map compiled by Wolfe and Morris (1996), available in digital format from Trusdell and others (2006), generalized for this compilation.

Average strike (azimuth) N. $54^{\circ}$ E. $\pm 11^{\circ} ;+54^{\circ} \pm 11^{\circ}$.

Length (km) 2.0 (end to end); 4.8 (cumulative).

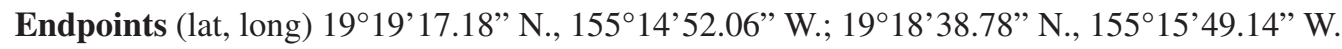

Sense of movement Normal.

Comments: From Wolfe and Morris (1996).

Dip Not reported.

Dip direction SE.

Comments: From Wolfe and Morris (1996).

Geomorphic expression The maximum geomorphic scarp height is approximately $40 \mathrm{~m}$ with a maximum scarp slope of about $24^{\circ}$.

Age of faulted deposits Faults cut surface lava flows that have an age of 750-1,500 yr B.P. (Wolfe and Morris, 1996). See Holcomb (1987) for details of ages of individual lava flows.

Timing of most recent paleoevent Holocene and latest Pleistocene $(<15 \mathrm{ka})$.

Comments: Not reported but estimated as late Holocene based on the ages of lava flows cut by the fault. Tilling and others (1976) do not identify faulting resulting from the 1975 Kalapana earthquake.

Recurrence interval Not reported.

Slip rate Unknown; probably $1-5 \mathrm{~mm} / \mathrm{yr}$.

Comments: Not reported. The estimated slip rate of $1-5 \mathrm{~mm} / \mathrm{yr}$ is based on faults cutting late Holocene lava flows and on a large scarp height similar in scale to 'Āpua Pali [2610m]. 


\section{References}

Holcomb, R.T., 1987, Eruptive history and long-term behavior of Kilauea Volcano, in Decker, R.W., Wright, T.L., and Stauffer, P.H., eds., Volcanism in Hawaii: U.S. Geological Survey Professional Paper 1350, v. 1, p. 261-350.

Tilling, R.I., Koyanagi, R.Y., Lipman., P.W, Lockwood, J.P., Moore, J.G., and Swanson, D.A., 1976, Earthquake and related catastrophic events. Island of Hawaii, November 29, 1975-A preliminary report: U.S. Geological Survey Circular $740,33 \mathrm{p}$.

Trusdell, F.A., Wolfe, E.W., and Morris, J., 2006, Digital database of the geologic map of the island of Hawai 'i: U.S. Geological Survey Data Series 144, supplement to Miscellaneous Investigations Series Map I-2524-A, 18 p., 1 sheet, scale 1:100,000.

Wolfe, E.W., and Morris, J., 1996, Geologic map of the island of Hawaii: U.S. Geological Survey Miscellaneous Investigations Series Map I-2524-A, 18 p., 3 sheets, scale 1:100,000.

\section{0j, Poliokeawe Pali Section, Hilina Fault System}

\section{Section number $2610 \mathrm{j}$.}

Section name Poliokeawe Pali section.

Comments: The Poliokeawe Pali section is located in the central part of the Hilina fault system.

Class of structure Not applicable.

Comments: None.

State Hawaii.

County Hawaii.

$\mathbf{1}^{\circ} \mathbf{x} \mathbf{2}^{\circ}$ sheet Hawaii, HI, 1:250,000 scale, 1975.

Comments: Located on the Ka' $\bar{u}$ Desert and Makaopuhi Crater 7.5-minute topographic sheets.

\section{Reliability of location Good.}

Comments: The fault trace is shown on the 1:100,000-scale geologic map as concealed (Wolfe and Morris, 1996), and the geomorphic fault scarp is present on the 1:24,000-scale Ka'ū Desert and Makaopuhi Crater topographic sheets. Cannon and Bürgmann (2001) present detailed fracture maps of the 1975 Kalapana earthquake based on fracture mapping in Mauna Ulu pāhoehoe lava flows (1969-1974) that flowed across Poliokeawe Pali.

Digital trace From the 1:100,000-scale geologic map compiled by Wolfe and Morris (1996), available in digital format from Trusdell and others (2006), generalized for this compilation.

Average strike (azimuth) N. $83^{\circ}$ E. $\pm 24^{\circ} ;+83^{\circ} \pm 24^{\circ}$.

Length $(\mathrm{km}) 17.0$ (end to end); 18.2 (cumulative).

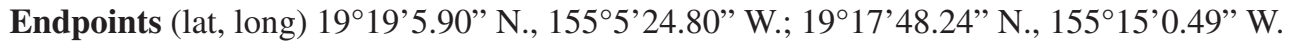

\section{Sense of movement Normal.}

Comments: From Wolfe and Morris (1996).

Dip $23^{\circ} \pm 24^{\circ}$.

Comments: Based on 12 piercing-point measurements found along Poliokeawe Pali in Mauna Ulu lava flows (1969-1974) that were fractured by the 1975 Kalapana earthquake. The average plunge of the slip vector has a mean angular direction of $23^{\circ}$ with a mean angular deviation (one-sigma) of $24^{\circ}$ (Cannon and Bürgmann, 2001). 
Dip direction S. $0^{\circ}$ E. $\pm 8^{\circ}$.

Comments: Based on 52 piercing-point measurements found along Poliokeawe Pali in Mauna Ulu lava flows (1969-1974) fractured by the 1975 Kalapana earthquake. The average piercing-point azimuth is S. $0^{\circ}$ E. with average deviation (two-sigma) of $8^{\circ}$ (Cannon and others, 2001).

Geomorphic expression The maximum geomorphic scarp height is approximately $170 \mathrm{~m}$ with a scarp slope of about $33^{\circ}$.

Age of faulted deposits Faults cut surface lava flows that have ages of 200-750 yr B.P., 750-1,500 yr B.P., and 1,500-3,000 yr B.P. (Wolfe and Morris, 1996). The Mauna Ulu lava flows (1969-1974) cover Poliokeawe Pali to the east and are cut by the faults. See Holcomb (1987) for details of ages of individual lava flows.

\section{Timing of most recent paleoevent Historic (1975).}

Comments: The maximum horizontal and vertical fault offsets across Poliokeawe Pali from the 1975 Kalapana earthquake are $1.95 \pm 0.05 \mathrm{~m}$ and $-0.53 \pm 0.03 \mathrm{~m}$, respectively (one-sigma instrument measurement uncertainty) (Cannon and others, 2001). A negative vertical fault offset indicates hanging wall-down motion. Tilling and others (1976) identify faulting that resulted from the 1975 Kalapana earthquake on only the eastern Poliokeawe Pali fault. Cannon and Bürgmann (2001) present a Poliokeawe Pali fault rupture map for the 1975 Kalapana earthquake for regions of Poliokeawe Pali covered by Mauna Ulu lava flows (1969-1974).

\section{Recurrence interval 120-150 yrs.}

Comments: Based on a field site on Poliokeawe Pali where the 1975 Kalapana earthquake offset both 350-450 yr B.P. lava flows and Mauna Ulu lava flows (1969-1974) along the same fracture (Cannon and Bürgmann, 2001). The fracture in the older lava flow has $90 \mathrm{~cm}$ of total offset while the Mauna Ulu lava flow only has a total offset of $29 \mathrm{~cm}$.

\section{Slip rate $>5 \mathrm{~mm} / \mathrm{yr}$.}

Comments: Kellogg and Chadwick (1987) first determined fault offsets in prehistoric and Mauna Ulu lava flows (1969-1974) along Poliokeawe Pali. Building on their work, Cannon and Bürgmann (2001) calculated fault slip rates based on fault offsets in prehistoric 400-750 yr B.P. lava flows for Poliokeawe Pali. The calculated slip rates are approximately $2.5 \mathrm{~mm} / \mathrm{yr}$ horizontal and $-5.6 \mathrm{~mm} / \mathrm{yr}$ vertical (a negative vertical rate indicates hanging wall-down motion), which yields a net slip rate of about $6.1 \mathrm{~mm} / \mathrm{yr}$.

\section{References}

Cannon, E.C., and Bürgmann, R., 2001, Prehistoric fault offsets of the Hilina fault system, south flank of Kilauea Volcano, Hawaii: Journal of Geophysical Research, v. 106, no. B3, p. 4,207-4,219.

Cannon, E.C., Bürgmann, R., and Owen, S.E., 2001, Shallow normal faulting and block rotation associated with the 1975 Kalapana earthquake, Kilauea Volcano, Hawaii: Bulletin of the Seismological Society of America, v. 91, no. 6, p. 1553-1562.

Holcomb, R.T., 1987, Eruptive history and long-term behavior of Kilauea Volcano, in Decker, R.W., Wright, T.L., and Stauffer, P.H., eds., Volcanism in Hawaii: U.S. Geological Survey Professional Paper 1350, v. 1, p. 261-350.

Kellogg, J.N., and Chadwick, W., 1987, Neotectonic study of the Hilina fault system, Kilauea, Hawaii: Geological Society of America Abstracts with Programs, v. 19, no. 6, p. 394.

Tilling, R.I., Koyanagi, R.Y., Lipman., P.W, Lockwood, J.P., Moore, J.G., and Swanson, D.A., 1976, Earthquake and related catastrophic events. Island of Hawaii, November 29, 1975-A preliminary report: U.S. Geological Survey Circular 740, 33 p.

Trusdell, F.A., Wolfe, E.W., and Morris, J., 2006, Digital database of the geologic map of the island of Hawai'i: U.S. Geological Survey Data Series 144, supplement to Miscellaneous Investigations Series Map I-2524-A, 18 p., 1 sheet, scale 1:100,000.

Wolfe, E.W., and Morris, J., 1996, Geologic map of the island of Hawaii: U.S. Geological Survey Miscellaneous Investigations Series Map I-2524-A, 18 p., 3 sheets, scale 1:100,000.

\section{0k, ‘Āinahou Section, Hilina Fault System}

Section number 2610k. 
Section name 'Āinahou section.

Comments: Informally named by the senior author based on 'Āinahou Ranch located approximately $3.5 \mathrm{~km}$ northwest of the fault section. The 'Āinahou section is a normal-fault splay off of the adjacent Poliokeawe Pali section [2610j] and is located along the central portion of the Hilina fault system.

Class of structure Not applicable.

Comments: None.

State Hawaii.

County Hawaii.

$\mathbf{1}^{\circ} \mathbf{x}{ }^{\circ}$ sheet Hawaii, HI, 1:250,000 scale, 1975.

Comments: Located on the Makaopuhi Crater 7.5-minute topographic sheet.

Reliability of location Poor.

Comments: The fault trace is identified on the 1:100,000-scale geologic map as concealed (Wolfe and Morris, 1996), and the geomorphic fault scarp is present on the 1:24,000-scale Makaopuhi Crater topographic map.

Digital trace From the 1:100,000-scale geologic map compiled by Wolfe and Morris (1996), available in digital format from Trusdell and others (2006), generalized for this compilation.

Average strike (azimuth) N. $85^{\circ}$ E. $\pm 26^{\circ} ;+85^{\circ} \pm 26^{\circ}$.

Length $(\mathrm{km}) 2.1$ (end to end); 2.2 (cumulative).

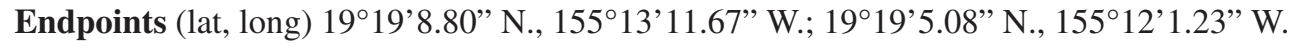

\section{Sense of movement Normal.}

Comments: From Wolfe and Morris (1996).

Dip Not reported.

Dip direction S.

Comments: From Wolfe and Morris (1996).

Geomorphic expression The maximum geomorphic scarp height is approximately $40 \mathrm{~m}$ with a maximum scarp slope of about $13^{\circ}$.

Age of faulted deposits Faults cut surface lava flows that range in age from the Mauna Ulu lava flows (1969-1971) to 1,500-3,000 yr B.P. (Wolfe and Morris, 1996). See Holcomb (1987) for details on ages of individual lava flows.

Timing of most recent paleoevent Holocene and latest Pleistocene $(<15 \mathrm{ka})$.

Comments: Not reported but estimated as late Holocene based on the ages of lava flows cut by the fault. Tilling and others (1976) do not report faulting resulting from the 1975 Kalapana earthquake.

\section{Recurrence interval Not reported.}

Slip rate Unknown; probably $1-5 \mathrm{~mm} / \mathrm{yr}$.

Comments: Not reported. The estimated slip rate of $1-5 \mathrm{~mm} / \mathrm{yr}$ is based on faults cutting late Holocene lava flows and on a large scarp height similar in scale to 'Āpua Pali [2610m].

\section{References}

Holcomb, R.T., 1987, Eruptive history and long-term behavior of Kilauea Volcano, in Decker, R.W., Wright, T.L., and Stauffer, P.H., eds., Volcanism in Hawaii: U.S. Geological Survey Professional Paper 1350, v. 1, p. 261-350. 
Tilling, R.I., Koyanagi, R.Y., Lipman., P.W, Lockwood, J.P., Moore, J.G., and Swanson, D.A., 1976, Earthquake and related catastrophic events. Island of Hawaii, November 29, 1975-A preliminary report: U.S. Geological Survey Circular 740, 33 p.

Trusdell, F.A., Wolfe, E.W., and Morris, J., 2006, Digital database of the geologic map of the island of Hawai 'i: U.S. Geological Survey Data Series 144, supplement to Miscellaneous Investigations Series Map I-2524-A, 18 p., 1 sheet, scale $1: 100,000$.

Wolfe, E.W., and Morris, J., 1996, Geologic map of the island of Hawaii: U.S. Geological Survey Miscellaneous Investigations Series Map I-2524-A, 18 p., 3 sheets, scale 1:100,000.

\section{1, Hōlei Pali Section, Hilina Fault System}

Section number 26101 .

Section name Hōlei Pali section.

Comments: The Hōlei Pali section is located in the central to eastern part of the Hilina fault system.

Class of structure Not applicable.

Comments: None.

State Hawaii.

County Hawaii.

$\mathbf{1}^{\circ} \mathbf{x} \mathbf{2}^{\circ}$ sheet Hawaii, HI, 1:250,000 scale, 1975.

Comments: Located on the Makaopuhi Crater 7.5-minute topographic sheet.

Reliability of location Good.

Comments: The fault trace is shown on the 1:100,000-scale geologic map as concealed (Wolfe and Morris, 1996), and the geomorphic fault scarp is visible on the 1:24,000-scale Makaopuhi Crater topographic sheet. Cannon and Bürgmann (2001) present detailed fracture maps of the 1975 Kalapana earthquake based on fracture mapping in Mauna Ulu pāhoehoe lava flows (1969-1974) that flowed across Hōlei Pali.

Digital trace From the 1:100,000-scale geologic map compiled by Wolfe and Morris (1996), available in digital format from Trusdell and others (2006), generalized for this compilation.

Average strike (azimuth) N. $71^{\circ}$ E. $\pm 23^{\circ} ;+71^{\circ} \pm 23^{\circ}$.

Length $(\mathrm{km}) 13.3$ (end to end); 16.6 (cumulative).

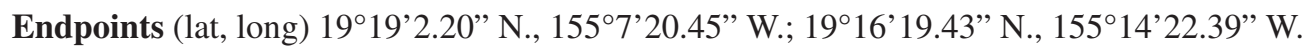

Sense of movement Normal.

Comments: From Tilling and others (1976), Lipman and others (1985), and Wolfe and Morris (1996).

Dip $23^{\circ} \pm 07^{\circ}$.

Comments: Based on 15 piercing-point measurements along Hōlei Pali in Mauna Ulu lava flows (1969-1974) that were fractured by the 1975 Kalapana earthquake. The average plunge of the slip vector has a mean angular direction of $23^{\circ}$ with a mean angular deviation (one-sigma) of $7^{\circ}$ (Cannon and Bürgmann, 2001).

Dip direction S. $29^{\circ}$ E. $\pm 5^{\circ}$.

Comments: Based on 26 piercing-point measurements along Hōlei Pali in Mauna Ulu lava flows (1969-1974) that were fractured by the 1975 Kalapana earthquake. The average piercing-point azimuth is S. $29^{\circ}$ E. with average deviation (two-sigma) of $5^{\circ}$ (Cannon and others, 2001). Additional information on dip directions is available from Tilling and others (1976), Lipman and others (1985), Wolfe and Morris (1996), and Cannon and Bürgmann (2001).

Geomorphic expression The maximum geomorphic scarp height is approximately $210 \mathrm{~m}$ with a scarp slope of about $29^{\circ}$. 
Age of faulted deposits Faults cut surface lava flows that have ages of 200-750 yr B.P., 750-1,500 yr B.P., and 1,500-3,000 yr B.P. The Mauna Ulu lava flows (1969-1974) cover Hōlei Pali to the east and are cut by the fault. See Holcomb (1987) for details of ages of individual lava flows.

Timing of most recent paleoevent Historic (1975).

Comments: The maximum horizontal and vertical fault offsets across Hōlei Pali from the 1975 Kalapana earthquake are $2.80 \pm 0.23 \mathrm{~m}$ and $-1.71 \pm 0.02 \mathrm{~m}$, respectively (one-sigma instrument measurement uncertainty) (Cannon and others, 2001). (A negative vertical fault offset indicates hanging wall-down motion.) Tilling and others (fig. 16, 1976) indicate $<1.0 \mathrm{~m}$ vertical displacement for the 1975 Kalapana earthquake.

Recurrence interval 190-650 yrs.

Comments: Based on a field site on Hōlei Pali where the 1975 Kalapana earthquake faulted both 200-750 yr B.P. lava flows and Mauna Ulu lava flows (1969-1974) along the same fracture (Cannon and Bürgmann, 2001). The fracture in the older lava flow has $80 \mathrm{~cm}$ of total offset while the Mauna Ulu lava flow only has a total offset of $67 \mathrm{~cm}$.

Slip rate $>5 \mathrm{~mm} / \mathrm{yr}$.

Comments: Kellogg and Chadwick (1987) first determined fault offsets in prehistoric and Mauna Ulu lava flows (1969-1974) along Hōlei Pali. Building on their work, Cannon and Bürgmann (2001) calculated fault slip rates based on offsets in 400-750 yr B.P. lava flows for Hōlei Pali. The calculated slip rates are approximately $4.6 \mathrm{~mm} / \mathrm{yr}$ horizontal and $-2.9 \mathrm{~mm} / \mathrm{yr}$ vertical (a negative vertical rate indicates hanging wall-down motion), which yields a net slip rate of about $5.4 \mathrm{~mm} / \mathrm{yr}$. The slip rate in 750-1,500 yr B.P. lava flows was approximately $3.0 \mathrm{~mm} / \mathrm{yr}$ horizontal and $-1.0 \mathrm{~mm} / \mathrm{yr}$ vertical, yielding a net slip of about $3.1 \mathrm{~mm} / \mathrm{yr}$. However, fractures are more poorly preserved in older lava flows making offset measurement more difficult in the field. Thus, the slip rate is estimated to be $>5 \mathrm{~mm} / \mathrm{yr}$, but probably close to $5 \mathrm{~mm} / \mathrm{yr}$ based on field observations and on a similar scarp height to Poliokeawe Pali [2610j] that has a $>5 \mathrm{~mm} / \mathrm{yr}$ estimated slip rate.

\section{References}

Cannon, E.C., and Bürgmann, R., 2001, Prehistoric fault offsets of the Hilina fault system, south flank of Kilauea Volcano, Hawaii: Journal of Geophysical Research, v. 106, no. B3, p. 4,207-4,219.

Cannon, E.C., Bürgmann, R., and Owen, S.E., 2001, Shallow normal faulting and block rotation associated with the 1975 Kalapana earthquake, Kilauea Volcano, Hawaii: Bulletin of the Seismological Society of America, v. 91, no. 6, p. $1,553-1,562$.

Holcomb, R.T., 1987, Eruptive history and long-term behavior of Kilauea Volcano, in Decker, R.W., Wright, T.L., and Stauffer, P.H., eds., Volcanism in Hawaii: U.S. Geological Survey Professional Paper 1350, v. 1, p. 261-350.

Kellogg, J.N., and Chadwick, W., 1987, Neotectonic study of the Hilina fault system, Kilauea, Hawaii: Geological Society of America Abstracts with Programs, v. 19, no. 6, p. 394.

Lipman, P.W., Lockwood, J.P., Okamura, R.T., Swanson, D.A., and Yamashita, K.M., 1985, Ground deformation associated with the 1975 magnitude-7.2 earthquake and resulting changes in activity of Kilauea Volcano, Hawaii: U.S. Geological Survey Professional Paper 1276, 45 p.

Tilling, R.I., Koyanagi, R.Y., Lipman., P.W, Lockwood, J.P., Moore, J.G., and Swanson, D.A., 1976, Earthquake and related catastrophic events. Island of Hawaii, November 29, 1975-A preliminary report: U.S. Geological Survey Circular 740, 33 p.

Trusdell, F.A., Wolfe, E.W., and Morris, J., 2006, Digital database of the geologic map of the island of Hawai'i: U.S. Geological Survey Data Series 144, supplement to Miscellaneous Investigations Series Map I-2524-A, 18 p., 1 sheet, scale 1:100,000.

Wolfe, E.W., and Morris, J., 1996, Geologic map of the island of Hawaii: U.S. Geological Survey Miscellaneous Investigations Series Map I-2524-A, 18 p., 3 sheets, scale 1:100,000.

\section{0m, ‘Āpua Pali Section, Hilina Fault System}

Section number $2610 \mathrm{~m}$.

Section name 'Āpua Pali section.

Comments: The 'Āpua Pali section is located in the central to eastern region of the Hilina fault system.

Class of structure Not applicable.

Comments: None. 
State Hawaii.

County Hawaii.

$\mathbf{1}^{\circ} \times \mathbf{2}^{\circ}$ sheet Hawaii, HI, 1:250,000 scale, 1975.

Comments: Located on the Makaopuhi Crater and Kalapana 7.5-minute topographic sheets.

\section{Reliability of location Good.}

Comments: The fault trace is identified on the 1:100,000-scale geologic map as concealed (Wolfe and Morris, 1996), and the geomorphic fault scarp is present on the 1:24,000-scale Makaopuhi Crater and Kalapana topographic maps. Cannon and Bürgmann (2001) present detailed fracture maps of the 1975 Kalapana earthquake based on fracture mapping in Mauna Ulu pāhoehoe lava flows (1969-1974) that flowed across ‘Āpua Pali.

Digital trace From the 1:100,000-scale geologic map compiled by Wolfe and Morris (1996), available in digital format from Trusdell and others (2006), generalized for this compilation.

Average strike (azimuth) N. $65^{\circ}$ E. $\pm 18^{\circ} ;+65^{\circ} \pm 18^{\circ}$.

Length $(\mathrm{km}) 6.8$ (end to end); 7.2 (cumulative).

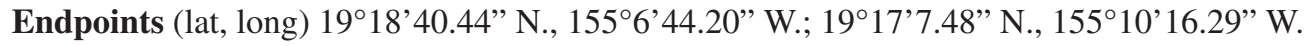

Sense of movement Normal.

Comments: From Wolfe and Morris (1996).

Dip $13^{\circ} \pm 15^{\circ}$.

Comments: Based on nine piercing-point measurements along 'Āpua Pali in Mauna Ulu lava flows (1969-1974) that were fractured by the 1975 Kalapana earthquake. The average plunge of the slip vector has a mean angular direction of $13^{\circ}$ with a mean angular deviation (one-sigma) of $15^{\circ}$ (Cannon and Bürgmann, 2001).

Dip direction S. $25^{\circ} \mathrm{E} . \pm 4^{\circ}$.

Comments: Based on 186 piercing-point measurements along 'Āpua Pali in Mauna Ulu lava flows (1969-1974) that were fractured by the 1975 Kalapana earthquake. The average piercing-point azimuth is S. $25^{\circ}$ E. with average deviation (twosigma) of $4^{\circ}$ (Cannon and others, 2001). Additional information on dip directions is available from Wolfe and Morris (1996) and Cannon and Bürgmann (2001).

Geomorphic expression The maximum geomorphic scarp height is approximately $55 \mathrm{~m}$ with a scarp slope of about $20^{\circ}$.

Age of faulted deposits Faults cut surface lava flows that range in age from historic to 1,500-3,000 yr B.P. (Wolfe and Morris, 1996). The Mauna Ulu lava flows (1969-1974) cover 'Āpua Pali to the west and are cut by the fault. See Holcomb (1987) for details of ages of individual lava flows.

Timing of most recent paleoevent Historic (1975).

Comments: The maximum horizontal and vertical fault offsets across 'Āpua Pali from the 1975 Kalapana earthquake are $0.82 \pm 0.02 \mathrm{~m}$ and $-0.43 \pm 0.04 \mathrm{~m}$, respectively (one-sigma instrument measurement uncertainty) (Cannon and others, 2001). (A negative vertical fault offset indicates hanging wall-down motion.) Cannon and Bürgmann (2001) present an 'Āpua Pali fault rupture map for the 1975 Kalapana earthquake for 'Āpua Pali regions covered by Mauna Ulu lava flows (1969-1974).

Recurrence interval $20-40$ yrs.

Comments: Based on a field site on 'Āpua Pali where both 400-750 yr B.P. lava flows and Mauna Ulu lava flows (1969-1974) were faulted by the 1975 Kalapana earthquake along the same fracture (Cannon and Bürgmann, 2001). The fracture in the older lava flow has a total offset of $89 \mathrm{~cm}$ while the Mauna Ulu flow only has $5 \mathrm{~cm}$ of total offset. This recurrence interval range, which is based on 17-18 events, suggests frequent faulting, but this rate of earthquakes is not supported by the number of historic earthquakes that have produced fault rupture on the south flank of Kîlauea. Non-tectonic movement of the fracture may have occurred. 
Slip rate $1-5 \mathrm{~mm} / \mathrm{yr}$.

Comments: Kellogg and Chadwick (1987) first determined fault offsets in prehistoric and Mauna Ulu (1969-1974) lava flows along 'Āpua Pali. Building on their work, Cannon and Bürgmann (2001) calculated fault slip rates based on fault offsets in 400-750 yr B.P. lava flows for 'Āpua Pali. The calculated slip rates are approximately $0.4 \mathrm{~mm} / \mathrm{yr}$ horizontal and $-0.1 \mathrm{~mm} / \mathrm{yr}$ vertical (a negative vertical rate indicates hanging wall-down motion), which yield a net slip rate of about $0.4 \mathrm{~mm} / \mathrm{yr}$. However, fracture preservation may be poor, as indicated by the frequent estimated recurrence interval of 20-40 years. Poliokeawe Pali [2610j] and Hōlei Pali [26101] have scarp heights approximately four times larger than the 'Āpua Pali's scarp, with total offset that indicate rates of approximately 5-6 mm/yr. This suggests that, based on scarp height, 'Āpua Pali may have an inferred rate of 1-2 mm/yr. Thus, the estimated slip rate falls in the $1-5 \mathrm{~mm} / \mathrm{yr}$ category, but the actual rate is probably close to $1-2 \mathrm{~mm} / \mathrm{yr}$ based on field observations and on comparison of scaled slip rates with Poliokeawe Pali [2610j] and Hōlei Pali [26101].

\section{References}

Cannon, E.C., and Bürgmann, R., 2001, Prehistoric fault offsets of the Hilina fault system, south flank of Kilauea Volcano, Hawaii: Journal of Geophysical Research, v. 106, no. B3, p. 4,207-4,219.

Cannon, E.C., Bürgmann, R., and Owen, S.E., 2001, Shallow normal faulting and block rotation associated with the 1975

Kalapana earthquake, Kilauea Volcano, Hawaii: Bulletin of the Seismological Society of America, v. 91, no. 6, p. 1,553-1,562.

Holcomb, R.T., 1987, Eruptive history and long-term behavior of Kilauea Volcano, in Decker, R.W., Wright, T.L., and

Stauffer, P.H., eds., Volcanism in Hawaii: U.S. Geological Survey Professional Paper 1350, v. 1, p. 261-350.

Kellogg, J.N., and Chadwick, W., 1987, Neotectonic study of the Hilina fault system, Kilauea, Hawaii: Geological Society of America Abstracts with Programs, v. 19, no. 6, p. 394.

Trusdell, F.A., Wolfe, E.W., and Morris, J., 2006, Digital database of the geologic map of the island of Hawai'i: U.S. Geological Survey Data Series 144, supplement to Miscellaneous Investigations Series Map I-2524-A, 18 p., 1 sheet, scale $1: 100,000$.

Wolfe, E.W., and Morris, J., 1996, Geologic map of the island of Hawaii: U.S. Geological Survey Miscellaneous Investigations Series Map I-2524-A, 18 p., 3 sheets, scale 1:100,000.

\section{0n, Paliuli Section, Hilina Fault System}

\section{Section number $2610 \mathrm{n}$.}

Section name Paliuli section.

Comments: The Paliuli section is located in the eastern part of the Hilina fault system.

Class of structure Not applicable.

Comments: None.

State Hawaii.

County Hawaii.

$\mathbf{1}^{\circ} \times \mathbf{2}^{\circ}$ sheet Hawaii, HI, 1:250,000 scale, 1975.

Comments: Located on the Kalapana and Makaopuhi Crater 7.5-minute topographic sheets.

\section{Reliability of location Good.}

Comments: Both the surficial and concealed fault traces are shown on the 1:100,000-scale geologic map (Wolfe and Morris, 1996), and the geomorphic fault scarp is visible on the 1:24,000-scale Kalapana and Makaopuhi Crater topographic maps.

Digital trace From the 1:100,000-scale geologic map compiled by Wolfe and Morris (1996), available in digital format from Trusdell and others (2006), generalized for this compilation.

Average strike (azimuth) N. $76^{\circ}$ E. $\pm 11^{\circ} ;+76^{\circ} \pm 11^{\circ}$.

Length (km) 8.4 (end to end); 17.6 (cumulative).

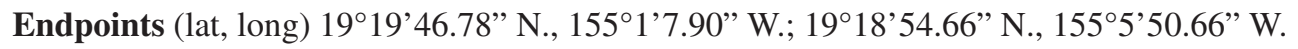


Sense of movement Normal.

Comments: From Wolfe and Morris (1996).

Dip Not reported.

Dip direction N, S.

Comments: From Wolfe and Morris (1996).

Geomorphic expression The maximum geomorphic scarp height is approximately $90 \mathrm{~m}$ with a scarp slope of about $30^{\circ}$.

Age of faulted deposits Faults cut surface lava flows that have an age of 400-750 yr B.P. (Wolfe and Morris, 1996). The eastern region contains a set of normal faults that cut 1,500-3,000 yr B.P. lava flows. In addition, some normal faults are buried by unfaulted 1985-1992 Pu'u 'Ō‘ō lava flows (D.A. Swanson, written commun., 2005). Faulting in the eastern region may be part of Pūlama pali [2610o] or Paliuli [2610n]. See Holcomb (1987) for details on ages of individual lava flows.

Timing of most recent paleoevent Late Quaternary $(<15 \mathrm{ka})$.

Comments: Not reported but estimated to be late Holocene based on the ages of lava flows cut by the faults. Tilling and others (1976) do not identify faulting resulting from the 1975 Kalapana earthquake. Faulting may have occurred due to the June 25, 1989, M 6.1 Kalapana earthquake. Wyss and Koyanagi (1992) report ground breakage along the road between Kalapana and Kapa'ahu, in the vicinity of the eastern termination of the fault section. Refer to the description of the June 25, 1989, Kalapana earthquake in this compilation for more details.

Recurrence interval Not reported.

Slip rate Unknown; probably $1-5 \mathrm{~mm} / \mathrm{yr}$.

Comments: Not reported. The estimated slip rate of $1-5 \mathrm{~mm} / \mathrm{yr}$ is based on faults that cut late Holocene lava flows and on a large scarp height similar in size to 'Āpua Pali [2610m].

\section{References}

Holcomb, R.T., 1987, Eruptive history and long-term behavior of Kilauea Volcano, in Decker, R.W., Wright, T.L., and Stauffer, P.H., eds., Volcanism in Hawaii: U.S. Geological Survey Professional Paper 1350, v. 1, p. 261-350.

Tilling, R.I., Koyanagi, R.Y., Lipman., P.W, Lockwood, J.P., Moore, J.G., and Swanson, D.A., 1976, Earthquake and related catastrophic events. Island of Hawaii, November 29, 1975-A preliminary report: U.S. Geological Survey Circular $740,33 \mathrm{p}$.

Trusdell, F.A., Wolfe, E.W., and Morris, J., 2006, Digital database of the geologic map of the island of Hawai 'i: U.S. Geological Survey Data Series 144, supplement to Miscellaneous Investigations Series Map I-2524-A, 18 p., 1 sheet, cale 1:100,000.

Wolfe, E.W., and Morris, J., 1996, Geologic map of the island of Hawaii: U.S. Geological Survey Miscellaneous Investigations Series Map I-2524-A, 18 p., 3 sheets, scale 1:100,000.

Wyss, M., and Koyanagi, R.Y., 1992, Isoseismal maps, macroseismic epicenters, and estimated magnitudes of historic earthquakes in the Hawaiian Islands: U.S. Geological Survey Bulletin 2006, 93 p.

\section{0o, Pūlama pali Section, Hilina Fault System}

Section number 2610 o.

Section name Pūlama pali section.

Comments: Informally named by the senior author to identify the easternmost fault section of the Hilina fault system.

Class of structure Not applicable.

Comments: None.

State Hawaii.

County Hawaii. 
$\mathbf{1}^{\circ} \times \mathbf{2}^{\circ}$ sheet Hawaii, HI, 1:250,000 scale, 1975.

Comments: Located on the Kalapana 7.5-minute topographic sheet.

Reliability of location Poor.

Comments: The fault trace is shown as concealed on the 1:100,000-scale geologic map (Wolfe and Morris, 1996), and the geomorphic fault scarp is visible on the 1:24,000-scale Kalapana topographic map.

Digital trace From the 1:100,000-scale geologic map compiled by Wolfe and Morris (1996), available in digital format from Trusdell and others (2006), generalized for this compilation.

Average strike (azimuth) N. $70^{\circ} \mathrm{E} . \pm 21^{\circ} ;+70^{\circ} \pm 21^{\circ}$.

Length $(\mathrm{km}) 14.0$ (end to end); 14.7 (cumulative).

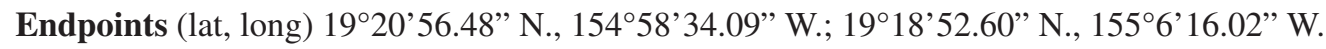

Sense of movement Normal.

Comments: From Wolfe and Morris (1996).

Dip Not reported.

Dip direction N, S to SE.

Comments: From Wolfe and Morris (1996).

Geomorphic expression The maximum geomorphic scarp height is $90-150 \mathrm{~m}$.

Age of faulted deposits Surface lava flows that have ages of 200-400 yr B.P., 400-750 yr B.P., and 1,500-3,000 yr B.P. cover inferred faults over most of Pūlama pali (Wolfe and Morris, 1996). The eastern region contains a set of normal faults that cut 1,500-3,000 yr B.P. lava flows. In addition, some normal faults are buried by unfaulted 1985-1992 $\mathrm{Pu}^{`} \mathrm{u}$ ' $\bar{O}^{`}{ }^{\circ} \mathrm{l}$ lava flows (D.A. Swanson, written commun., 2005). Faulting in the eastern region may be part of Pūlama pali [2610o] or Paliuli [2610n]. See Holcomb (1987) for details of ages of individual lava flows.

Timing of most recent paleoevent Holocene and latest Pleistocene $(<15 \mathrm{ka})$.

Comments: Not reported but estimate is based on late Holocene lava flows that are cut by the fault. Tilling and others (1976) do not report faulting that resulted from the 1975 Kalapana earthquake. Faulting may have occurred during the June 25, 1989, M 6.1 Kalapana earthquake. Wyss and Koyanagi (1992) report ground breakage along the road between Kalapana and Kapa'ahu in the vicinity of the eastern termination of the fault section. Refer to the description of the June 25, 1989, Kalapana earthquake in this compilation for details.

Recurrence interval Not reported.

Slip rate Unknown; probably $>5 \mathrm{~mm} / \mathrm{yr}$.

Comments: Not reported. The estimated slip rate of $>5 \mathrm{~mm} / \mathrm{yr}$ is based on faults that cut late Holocene lava flows and on a large scarp height similar in size to Hōlei Pali [26091].

\section{References}

Holcomb, R.T., 1987, Eruptive history and long-term behavior of Kilauea Volcano, in Decker, R.W., Wright, T.L., and Stauffer, P.H., eds., Volcanism in Hawaii: U.S. Geological Survey Professional Paper 1350, v. 1, p. 261-350.

Tilling, R.I., Koyanagi, R.Y., Lipman., P.W, Lockwood, J.P., Moore, J.G., and Swanson, D.A., 1976, Earthquake and related catastrophic events. Island of Hawaii, November 29, 1975-A preliminary report: U.S. Geological Survey Circular 740, 33 p.

Trusdell, F.A., Wolfe, E.W., and Morris, J., 2006, Digital database of the geologic map of the island of Hawai'i: U.S. Geological Survey Data Series 144, supplement to Miscellaneous Investigations Series Map I-2524-A, 18 p., 1 sheet, scale 1:100,000. 
Wolfe, E.W., and Morris, J., 1996, Geologic map of the island of Hawaii: U.S. Geological Survey Miscellaneous Investigations Series Map I-2524-A, 18 p., 3 sheets, scale 1:100,000.

Wyss, M., and Koyanagi, R.Y., 1992, Isoseismal maps, macroseismic epicenters, and estimated magnitudes of historic earthquakes in the Hawaiian Islands: U.S. Geological Survey Bulletin 2006, 93 p.

\section{1, L̄ōihi Seamount}

Structure number 2611.

Comments: See figure 1 for the location map of Lō'ihi Seamount, located offshore south of the Island of Hawai' $i$, and see figure 4 for the structure of the seamount.

Structure name Lō'ihi Seamount.

Comments: The name Lō'ihi, the Hawaiian word for "long," reflects the north-south elongate shape of the underwater volcano (Malahoff, 1987).

Synopsis Lo' 'ihi is the youngest seamount of the Hawaiian-Emperor island-seamount chain. The base of the volcano is approximately $5 \mathrm{~km}$ below sea level, and the summit platform is approximately $1.2 \mathrm{~km}$ below sea level (Caplan-Auerbach and Duennebier, 2001). Volcanic rocks from the seamount have preshield-stage alkalic, transitional, and shield-stage tholeiitic signatures (Clague and Dalrymple, 1987; Langenheim and Clague, 1987). Growing up through the Mauna Loa Punalu 'u slump and building concurrently with Hilina slump activity (fig. 1), Lō'ihi may rise above the sea surface within the next few tens of thousands of years (Moore and Chadwick, 1995). The seamount has a summit caldera and two major rift zones: the north and the south rift zones. Lō 'ihi is seismically active, and a seismic swarm in 1996 produced summit deformation (Caplan-Auerbach and Duennebier, 2001). Similar to the subaerial volcanoes of Hawai' $i$, magmatic activity and gravitational failure of the Lō'ihi volcanic edifice can generate underwater faulting and catastrophic mass movement.

Date of compilation September 16, 2006.

Compiler and affiliation Eric C. Cannon; Roland Bürgmann, University of California Berkeley.

Province Hawaiian-Emperor island-seamount chain.

Geologic setting Lō'ihi is the southeasternmost and youngest member of the Hawaiian-Emperor island-seamount chain. The seamount has an age of probably less than 0.5 Ma (Malahoff, 1987) and has a height of about 4,000 m. However, the seamount still remains submerged on the deep southeastern flank of the Island of Hawai 'i (Caplan-Auerbach and Duennebier, 2001). Moore and Chadwick (1995) map the seafloor surface of Lō 'ihi as mostly submarine basaltic pillow lavas. Three significant debris avalanches are located on the east, west, and south flanks that cover about one-half of the volcano (fig. 1) (Malahoff, 1987; Moore and Chadwick, 1995).

\section{Number of sections 3.}

Comments: The three sections designated for Lō'ihi Seamount are Lō'ihi’s caldera [2611a], the north rift zone [2611b], and the south rift zone [2611c].

Average strike (azimuth) N. $43^{\circ} \mathrm{W} . \pm 77^{\circ} ;-43^{\circ} \pm 77^{\circ}$.

Length $(\mathrm{km}) 26.9$ (end to end); 42.1 (cumulative).

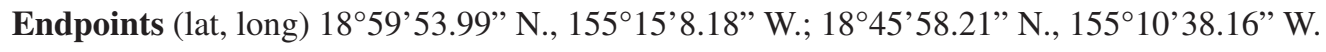

\section{References}

Caplan-Auerbach, J., and Duennebier, F.K., 2001, Seismicity and velocity structure of Loihi Seamount from the 1996 earthquake swarm: Bulletin of the Seismological Society of America, v. 91, no. 2, 178-190.

Clague, D.A., and Dalrymple, G.B., 1987, The Hawaiian-Emperor volcanic chain. Part I. Geologic evolution, in Decker, R.W., Wright, T.L., and Stauffer, P.H., eds., Volcanism in Hawaii: U.S. Geological Survey Professional Paper 1350, v. 1, p. 5-54. 


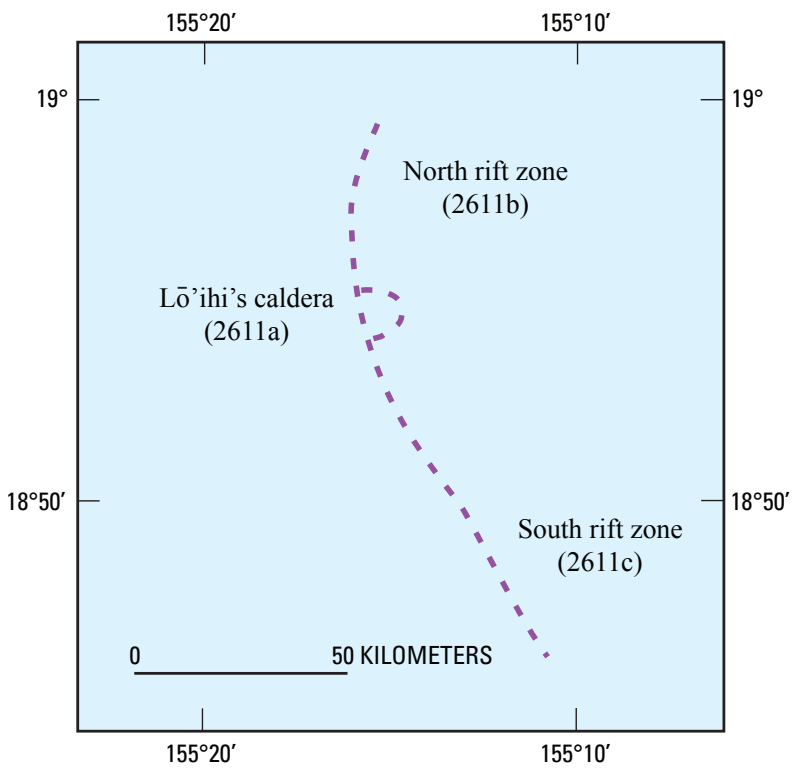

Figure 4. Lō'ihi Seamount with Lō'ihi’s caldera [2611a], the north rift zone [2611b], and the south rift zone [2611c]. From Malahoff (1987) and Caplan-Auerbach and Duennebier (2000).

Langenheim, V.A.M., and Clague, D.A., 1987, The Hawaiian-Emperor volcanic chain. Part II. Stratigraphic framework of volcanic rocks of the Hawaiian Islands, in Decker, R.W., Wright, T.L., and Stauffer, P.H., eds., Volcanism in Hawaii: U.S. Geological Survey Professional Paper 1350, v. 1, p. 55-84.

Malahoff, A., 1987, Geology of the summit of Loihi Submarine Volcano, in Decker, R.W., Wright, T.L., and Stauffer, P.H., eds., Volcanism in Hawaii: U.S. Geological Survey Professional Paper 1350, v. 1, p. 133-144.

Moore, J.G., and Chadwick, W.W., Jr., 1995, Offshore geology of Mauna Loa and adjacent areas, Hawaii, in Rhodes, J.M., and Lockwood, J.P., eds., Mauna Loa revealed—Structure, composition, history, and hazards: American Geophysical Union Geophysical Monograph, v. 92, p. 21-44.

\section{1a, Lō'ihi’s Caldera, Lō'ihi Seamount}

Section number 2611a.

Section name Lō'ihi’s caldera.

Class of structure Not applicable.

Comments: None.

State Hawaii.

County Hawaii.

$1^{\circ} \times 2^{\circ}$ sheet Offshore.

\section{Reliability of location Poor.}

Comments: Large contour intervals are used on maps showing the caldera. The bathymetric contour interval on maps from Malahoff (fig. 6.2, 1987), Smith and others (fig. 3d, 1999), and Caplan-Auerbach and Duennebier (fig. 2, 2001) are 50 fathoms (approximately $91 \mathrm{~m}$ ), $100 \mathrm{~m}$, and $100 \mathrm{~m}$, respectively. See figure 4 for the structure of the seamount. 
Digital trace Small-scale maps show the caldera. The map scales for Malahoff (fig. 6.2, 1987), Smith and others (fig. 3d, 1999), and Caplan-Auerbach and Duennebier (fig. 2, 2001) are approximately 1:220,000, 1:740,000, and 1:240,000, respectively. Traces are generalized for this compilation.

Average strike (azimuth) N. $88^{\circ}$ W. $\pm 102 ;-88^{\circ} \pm 102$.

Length $(\mathrm{km}) 5.7$ (end to end); 15.3 (cumulative).

Endpoints (lat, long.) $18^{\circ} 56^{\prime} 42.22^{\prime \prime}$ N., $155^{\circ} 15^{\prime} 7.34^{\prime \prime}$ W.; $18^{\circ} 53^{\prime} 36.15^{\prime \prime}$ N., $155^{\circ} 15^{\prime} 8.80^{\prime \prime}$ W.

Sense of movement Presumably extension, normal.

Dip Presumably near vertical to vertical.

Dip Direction Various along caldera faults and crater rims.

Geomorphic expression Prior to a 1996 seismic swarm, Malahoff (1987) described a summit caldera $2.7 \mathrm{~km}$ in diameter containing two pit craters, East Pit and West Pit. Caplan-Auerbach and Duennebier (2001) state that, coincident with a seismic swarm in July and August 1996 (maximum $\mathrm{M}_{\mathrm{L}} 4.9$ ), part of the summit caldera (about $100 \mathrm{~m}$ high) collapsed to form a third summit crater called Pele's Pit (600 m wide and $300 \mathrm{~m}$ deep).

Age of faulted deposits $<0.5$ Ma.

Comments: Malahoff (1987) estimates $<0.5$ Ma for the age of Lō'ihi.

Timing of most recent paleoevent Historic (1996).

Comments: The formation of Pele's Pit occurred in 1996 (Caplan-Auerbach and Duennebier, 2001).

Recurrence interval Not reported.

Slip rate Unknown; probably $>5 \mathrm{~mm} / \mathrm{yr}$.

Comments: Not reported. Lō'ihi is an actively growing and deforming submarine volcano with rift zones. The estimated slip rate of $>5 \mathrm{~mm} / \mathrm{yr}$ is based on slip rates for the calderas of Hawai 'i's two other active volcanoes, Moku'āweoweo caldera [2605a] on Mauna Loa Volcano, and Kīlauea's caldera [2608a] on Kīlauea Volcano.

\section{References}

Caplan-Auerbach, J., and Duennebier, F.K., 2001, Seismicity and velocity structure of Loihi Seamount from the 1996 earthquake swarm: Bulletin of the Seismological Society of America, v. 91, no. 2, 178-190.

Malahoff, A., 1987, Geology of the summit of Loihi Submarine Volcano, in Decker, R.W., Wright, T.L., and Stauffer, P.H., eds., Volcanism in Hawaii: U.S. Geological Survey Professional Paper 1350, v. 1, p. 133-144.

Smith, J.R., Malahoff, A., and Shor, A.N., 1999, Submarine geology of the Hilina slump and morpho-structural evolution of Kilauea volcano, Hawaii: Journal of Volcanology and Geothermal Research, v. 94, p. 59-88.

\section{1b, North Rift Zone, Lō'‘ihi Seamount}

Section number $2611 b$.

Section name North rift zone.

Class of structure Not applicable.

Comments: None.

State Hawaii.

County Hawaii. 
$1^{\circ} \times 2^{\circ}$ sheet Offshore.

Reliability of location Poor.

Comments: Large contour intervals are used on maps showing the north rift zone. The bathymetric contour interval on maps from Malahoff (fig. 6.2, 1987), Smith and others (fig. 3d, 1999), and Caplan-Auerbach and Duennebier (fig. 2, 2001) are 50 fathoms (approximately $91 \mathrm{~m}$ ), $100 \mathrm{~m}$, and $100 \mathrm{~m}$, respectively. See figure 4 for the structure of the seamount.

Digital trace Small-scale maps show the north rift zone. The map scales for Malahoff (fig. 6.2, 1987), Smith and others (fig. 3d, 1999), and Caplan-Auerbach and Duennebier (fig. 2, 2001) are approximately 1:220,000, 1:740,000, and 1:240,000, respectively. Traces are generalized for this compilation.

Average strike (azimuth) N. $8^{\circ}$ E. $\pm 12^{\circ} ;+8^{\circ} \pm 12^{\circ}$.

Length $(\mathrm{km}) 7.2$ (end to end); 9.0 (cumulative).

Endpoints (lat, long) $18^{\circ} 59^{\prime} 53.99^{\prime \prime}$ N., $155^{\circ} 15^{\prime} 8.18^{\prime \prime}$ W.; $18^{\circ} 56^{\prime} 1.18^{\prime \prime}$ N., $155^{\circ} 15^{\prime} 42.35^{\prime}$ W.

Sense of movement Presumably extension, normal faulting.

Dip Presumably near vertical to vertical.

Dip Direction Generally E to SE.

Geomorphic expression The north rift zone forms a bathymetrically high ridge that trends generally north and then ends trending northeast (Malahoff, 1987). Whereas Malahoff (1987) shows a single north rift zone, Smith and others (1999) interpret the north rift zone with an additional rift zone splay to the north. Moore and Chadwick (1995) comment that significant mass wasting of the volcanic edifice has occurred on Lō 'ihi, producing steep headwalls and leaving behind rift zones that resemble "narrow blade-like ridges."

Age of faulted deposits $<0.5 \mathrm{Ma}$.

Comments: Malahoff (1987) estimates $<0.5$ Ma for the age of Lō'ihi.

Timing of most recent paleoevent Holocene and latest Pleistocene $(<15 \mathrm{ka})$.

Comments: Caplan-Auerbach and Duennebier (2001) do not report whether deformation occurred on the north rift zone as a result of the 1996 seismic swarm.

Recurrence interval Not reported.

Slip rate Unknown; probably $>5 \mathrm{~mm} / \mathrm{yr}$.

Comments: Not reported. Lō'ihi is an actively growing and deforming submarine volcano with rift zones that probably have active extension. The estimated slip rate of $>5 \mathrm{~mm} / \mathrm{yr}$ is based on slip rates for the rift zones found on Hawai 'i's two other active volcanoes, the rift zones of Mauna Loa [2605b, c] and Kīlauea [2608b, c] Volcanoes.

\section{References}

Caplan-Auerbach, J., and Duennebier, F.K., 2001, Seismicity and velocity structure of Loihi Seamount from the 1996 earthquake swarm: Bulletin of the Seismological Society of America, v. 91, no. 2, 178-190.

Malahoff, A., 1987, Geology of the summit of Loihi Submarine Volcano, in Decker, R.W., Wright, T.L., and Stauffer, P.H., eds., Volcanism in Hawaii: U.S. Geological Survey Professional Paper 1350, v. 1, p. 133-144.

Moore, J.G., and Chadwick, W.W., Jr., 1995, Offshore geology of Mauna Loa and adjacent areas, Hawaii, in Rhodes, J.M., and Lockwood, J.P., eds., Mauna Loa revealed-Structure, composition, history, and hazards: American Geophysical Union Geophysical Monograph, v. 92, p. 21-44.

Smith, J.R., Malahoff, A., and Shor, A.N., 1999, Submarine geology of the Hilina slump and morpho-structural evolution of Kilauea volcano, Hawaii: Journal of Volcanology and Geothermal Research, v. 94, p. 59-88. 


\section{1c, South Rift Zone, Lō'ihi Seamount}

Section number $2611 \mathrm{c}$.

Section name South rift zone.

Class of structure Not applicable. Comments: None.

State Hawaii.

County Hawaii.

$1^{\circ} \times 2^{\circ}$ sheet Offshore.

Reliability of location Poor.

Comments: Large contour intervals are used on maps showing the south rift zone. The bathymetric contour interval on maps from Malahoff (fig. 6.2, 1987), Smith and others (fig. 3d, 1999), and Caplan-Auerbach and Duennebier (fig. 2, 2001) are 50 fathoms (approximately $91 \mathrm{~m}$ ), $100 \mathrm{~m}$, and $100 \mathrm{~m}$, respectively. See figure 4 for the structure of the seamount.

Digital trace Small-scale maps show the south rift zone. The map scales for Malahoff (fig. 6.2, 1987), Smith and others (fig. 3d, 1999), and Caplan-Auerbach and Duennebier (fig. 2, 2001) are approximately 1:220,000, 1:740,000, and 1:240,000, respectively. Traces are generalized for this compilation.

Average strike (azimuth) N. $29^{\circ}$ W. $\pm 7^{\circ} ;-29^{\circ} \pm 7^{\circ}$.

Length (km) 17.7 (end to end); 17.8 (cumulative)

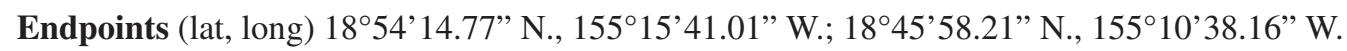

Sense of movement Presumably extension, normal faulting.

Dip Presumably near vertical to vertical.

Dip Direction Generally W to NW.

Geomorphic expression The south rift zone forms a bathymetrically high ridge that trends generally south to southsoutheast along the 17-km-long rift zone (Malahoff, 1987). Whereas Malahoff (1987) shows a single south rift zone, Smith and others (1999) interpret the south rift zone with an additional rift zone splay trending to the southwest. Moore and Chadwick (1995) comment that significant mass wasting of the volcanic edifice has occurred on Lō'ihi, producing steep headwalls and leaving behind rift zones that resemble "narrow blade-like ridges."

Age of faulted deposits $<0.5$ Ma.

Comments: Malahoff (1987) estimates $<0.5$ Ma for the age of Lō'ihi.

Timing of most recent paleoevent Holocene and latest Pleistocene $(<15 \mathrm{ka})$.

Comments: Caplan-Auerbach and Duennebier (2001) do not report whether deformation occurred on the south rift zone as a result of the 1996 seismic swarm.

Recurrence interval Not reported.

Slip rate Unknown; probably $>5 \mathrm{~mm} / \mathrm{yr}$.

Comments: Not reported. Lō'ihi is an actively growing and deforming submarine volcano with rift zones that probably have active extension. The estimated slip rate of $>5 \mathrm{~mm} / \mathrm{yr}$ is based on slip rates for the rift zones found on Hawai' i's two other active volcanoes, the rift zones of Mauna Loa [2605b, c] and Kîlauea [2608b, c] Volcanoes. 


\section{References}

Caplan-Auerbach, J., and Duennebier, F.K., 2001, Seismicity and velocity structure of Loihi Seamount from the 1996 earthquake swarm: Bulletin of the Seismological Society of America, v. 91, no. 2, 178-190.

Malahoff, A., 1987, Geology of the summit of Loihi Submarine Volcano, in Decker, R.W., Wright, T.L., and Stauffer, P.H., eds., Volcanism in Hawaii: U.S. Geological Survey Professional Paper 1350, v. 1, p. 133-144.

Moore, J.G., and Chadwick, W.W., Jr., 1995, Offshore geology of Mauna Loa and adjacent areas, Hawaii, in Rhodes, J.M., and Lockwood, J.P., eds., Mauna Loa revealed-Structure, composition, history, and hazards: American Geophysical Union Geophysical Monograph, v. 92, p. 21-44.

Smith, J.R., Malahoff, A., and Shor, A.N., 1999, Submarine geology of the Hilina slump and morpho-structural evolution of Kilauea volcano, Hawaii: Journal of Volcanology and Geothermal Research, v. 94, p. 59-88.

\section{Hawai'i Earthquakes Generating Surface Ruptures}

\section{June 1823, Kaimū Earthquake}

Name of earthquake Kaimū.

Comments: The name is based on the location given by Wyss and Koyanagi (1992). The Kaimū earthquake is the first historic Hawaiian earthquake listed by Wyss and Koyanagi (1992), who state that "The fissures at Kaimū created by the first known strong earthquake in Hawaii were examined by Ellis (1827) two months after the event. The effects described are similar to those due to the M7.2 Kalapana earthquake of November 1975" (p.35).

Affected structures Possibly the Hilina fault system [2610], including the Paliuli [2610n] and Pūlama pali [2610o] sections. Comments: Ellis (1827) comments on the ground rupture of the 1823 Kaimū earthquake, stating that "a chasm about a foot wide marked distinctly its course; this was generally open, though in some places it seemed as if the earth had closed up again" (quoted in Wyss and Koyanagi, p. 57, 1992). The ground fracture described by Ellis (1827) may correspond to the eastern tip of Paliuli [2610n] or Pūlama pali [2610o] sections. Wolfe and Morris (1996) show east-striking normal faults with hangingwall blocks down to the north for a region approximately $3 \mathrm{~km}$ southwest of Kaimū.

Date of earthquake June 1823 (date unknown), about 10:00 p.m. Hawaiian Standard Time (Wyss and Koyanagi, 1992).

Date of compilation September 16, 2006.

Compiler and affiliation Eric C. Cannon; Roland Bürgmann, University of California Berkeley.

Magnitude or intensity IX.

Comments: Modified Mercalli intensity (Wyss and Koyanagi, 1992).

Moment magnitude or seismic moment Not reported.

Location of epicenter Not reported.

Comments: Not reported by Wyss and Koyanagi (1992). The maximum intensity noted for this event is IX at Kaimū (Ellis, 1827 ; Wyss and Koyanagi, 1992), which is located at approximately $19^{\circ} 22^{\prime}$ N., $154^{\circ} 58^{\prime}$ W.

Depth of hypocenter Not reported.

Sense of movement Not reported.

Dip Not reported.

Maximum slip at surface Not reported.

Geophysical average slip Not reported. 
Length of surface rupture Not reported.

\section{References}

Ellis, W., 1827, Narrative of a tour through Hawaii, or Owhyhee, with observations on the natural of the Sandwich Islands, and remarks on the manners, customs, traditions, history and language of the inhabitants: London, H. Fisher, Son, and P. Jackson, $480 \mathrm{p}$.

Wolfe, E.W., and Morris, J., 1996, Geologic map of the island of Hawaii: U.S. Geological Survey Miscellaneous Investigations Series Map I-2524-A, 18 p., 3 pl., scale 1:100,000.

Wyss, M., and Koyanagi, R.Y., 1992, Isoseismal maps, macroseismic epicenters, and estimated magnitudes of historic earthquakes in the Hawaiian Islands: U.S. Geological Survey Bulletin 2006, 93 p.

\section{April 2, 1868, Great Ka' $\bar{u}$ Earthquake}

Name of earthquake Great Ka' $\mathrm{u}$.

Comments: This is the largest historic earthquake to strike Hawai ' $i$ (Wyss and Koyanagi, 1992). Wyss (1988) refers to this earthquake as the Great Ka' $\bar{u}$ Earthquake. There was a foreshock sequence lasting five days and an aftershock sequence lasting perhaps a decade (Wyss, 1988). An approximately M7 earthquake on March 28, 1868, at 1:28 p.m. Hawaiian Standard Time, considered to be the initial foreshock, generated a maximum IX Modified Mercalli intensity at Kahuku (approximate location at $19^{\circ} 04^{\prime}$ N., $155^{\circ} 41^{\prime}$ W.) (Wyss and Koyanagi, 1992).

Affected structures Possibly the Kahuku fault system [2604], Mauna Loa Volcano [2605], Ka‘ōiki seismic zone [2606], Ka'ōiki-Honu'apo fault system [2607], Kīlauea Volcano [2608], Koa'e fault system [2609], and Hilina fault system [2610].

Date of earthquake April 2, 1868, 3:40 p.m. Hawaiian Standard Time (Wyss and Koyanagi, 1992).

Date of compilation September 16, 2006.

Compiler and affiliation Eric C. Cannon; Roland Bürgmann, University of California Berkeley.

Magnitude or intensity Approximately M7.9, XII.

Comments: Modified Mercalli intensity is based on historic accounts of shaking and damage (Wyss and Koyanagi, 1992).

Moment magnitude or seismic moment $\mathrm{M}_{0}=10^{21} \mathrm{~N}$.

Comments: Based on the assumption of a M8 earthquake, $8 \mathrm{~m}$ dislocation, and a 4,000 $\mathrm{km}^{2}$ ruptured fault surface (Wyss, 1988).

Location of epicenter Southern Hawai 'i.

Comments: The location of the epicenter is estimated to be at $19.2^{\circ}$ N., $155.5^{\circ}$ W. (Wyss, 1988; Wyss and Koyanagi, 1992).

Depth of hypocenter Approximately $9 \mathrm{~km}$.

Comments: The earthquake may have ruptured a near-horizontal fault at a depth of approximately $9 \mathrm{~km}$ (Wyss, 1988), possibly corresponding to the boundary between the Pacific oceanic lithosphere and volcanic edifice.

\section{Sense of movement SE.}

Comments: From Wyss and Koyanagi (1992).

Dip Near horizontal.

Comments: The earthquake may have nucleated on a near-horizontal fault plane, possibly on the boundary between the Pacific oceanic lithosphere and volcanic edifice (Wyss, 1988).

Maximum slip at surface $1.2-2.1 \mathrm{~m}$.

Comments: Permanent coseismic subsidence is reported by Brigham (1909) along the coast from Kapoho to Punalu 'u (Wyss, 1988). 


\section{Geophysical average slip $8 \mathrm{~m}$.}

Comments: As calculated from a dislocation model based on an approximately M8 earthquake and a 4,000 km² fault area (Wyss, 1988).

\section{Length of surface rupture Not reported.}

\section{References}

Brigham, W.T., 1909, The volcanoes of Kilauea and Mauna Loa on the island of Hawaii: Memories of the Bernice Pauahi Bishop Museum, v. 2, p. 478-497.

Wyss, M., 1988, A proposed source model for the Great Kau, Hawaii, Earthquake of 1868: Bulletin of the Seismological Society of America, v. 78, no. 4, p. 1,450-1,462.

Wyss, M., and Koyanagi, R.Y., 1992, Isoseismal maps, macroseismic epicenters, and estimated magnitudes of historic earthquakes in the Hawaiian Islands: U.S. Geological Survey Bulletin 2006, 93 p.

\section{June 27, 1962, Ka'ōiki Earthquake}

Name of earthquake Ka‘ōiki.

Comments: This name is based on the location given by Wyss and Koyanagi (1992). Jackson and others (1992) state that fractures observed in the field termed "old cracks" might be associated with the June 27, 1962, earthquake, or possibly the 1868 Great Ka' $\mathrm{u}$ earthquake. The focal mechanisms for the 1962, 1974, and $1983 \mathrm{Ka}$ 'ōiki earthquakes are similar and are interpreted to represent right-lateral strike-slip motion on northeast-trending faults (Endo, 1985; Jackson and others, 1992).

Affected structures Possibly the Ka‘ōiki seismic zone [2606] and Ka‘ōiki-Honu‘apo fault system [2607].

Date of earthquake June 27, 1962, 6:27 p.m. Hawaiian Standard Time (Wyss and Koyanagi, 1992).

Date of compilation September 16, 2006.

Compiler and affiliation Eric C. Cannon; Roland Bürgmann, University of California Berkeley.

Magnitude or intensity $\mathrm{M}_{\mathrm{s}} 6.1$, VI.

Comments: Magnitude and Modified Mercalli intensity from Wyss and Koyanagi (1992).

Moment magnitude or seismic moment Not reported.

Location of epicenter $19.40^{\circ} \mathrm{N}$, $155.45^{\circ} \mathrm{W}$.

Comments: From Wyss and Koyanagi (1992).

Depth of hypocenter $8 \mathrm{~km}$.

Comments: From Wyss and Koyanagi (1992).

Sense of movement Right-lateral strike-slip.

Comments: Right-lateral strike-slip motion on northeast-trending faults (Jackson and others, 1992). Jackson and others (1992) discuss a zone of left-stepping en echelon cracks in basalt. The left-stepping geometry is consistent with right-lateral strike-slip motion on a northeast-trending fault.

Dip Vertical to near vertical.

Comments: Based on focal-mechanism solutions for the 1962 earthquake (Jackson and others, 1992).

Maximum slip at surface $0.88 \mathrm{~m}$.

Comments: Jackson and others (1992) report a maximum of $88 \mathrm{~cm}$ horizontal cumulative displacement across the rupture zone. An unknown number of earthquakes contributed to the cumulative displacement.

Geophysical average slip Not reported. 
Length of surface rupture Approximately $0.1 \mathrm{~km}$.

Comments: Jackson and others (fig. 13, 1992) map three fractures generally trending northeast in a left-stepping en echelon zone possibly resulting from the $1962 \mathrm{Ka}$ 'oiki earthquake. The cumulative length of the three fractures is approximately $100 \mathrm{~m}$.

\section{References}

Endo, E.T., 1985, Seismotectonic framework for the southeast flank of Mauna Loa volcano, Hawaii: Seattle, University of Washington, Ph.D. dissertation, 349 p.

Jackson, M.D., Endo, E.T., Delaney, P.T., Árnadottir, T., and Rubin, A.M., 1992, Ground ruptures of the 1974 and 1983 Kaoiki earthquakes, Mauna Loa Volcano, Hawaii: Journal of Geophysical Research, v. 97, no. B6, p. 8,775-8,796.

Wyss, M., and Koyanagi, R.Y., 1992, Isoseismal maps, macroseismic epicenters, and estimated magnitudes of historic earthquakes in the Hawaiian Islands: U.S. Geological Survey Bulletin 2006, 93 p.

\section{November 30, 1974, Ka‘ōiki Earthquake}

Name of earthquake Ka`ōiki.

Comments: This name is based on the location given by Wyss and Koyanagi (1992). Focal mechanisms for the 1962, 1974, and $1983 \mathrm{Ka}$ 'ōiki earthquakes are similar and are interpreted to represent right-lateral strike-slip motion on northeast-trending faults (Endo, 1985; Jackson and others, 1992).

Affected structures The Ka‘ōiki seismic zone [2606] and possibly the Ka‘ōiki-Honu 'apo fault system [2607].

Date of earthquake November 30, 1974, 3:54 a.m. Hawaiian Standard Time (Wyss and Koyanagi, 1992).

Date of compilation September 16, 2006.

Compiler and affiliation Eric C. Cannon; Roland Bürgmann, University of California Berkeley.

Magnitude or intensity $\mathrm{M}_{\mathrm{L}} 5.5$, IV.

Comments: Magnitude from Jackson and others (1992) and Wyss and Koyanagi (1992); Modified Mercalli intensity from Wyss and Koyanagi (1992).

Moment magnitude or seismic moment Not reported.

Location of epicenter $19.44^{\circ} \mathrm{N}$., $55.42^{\circ} \mathrm{W}$.

Comments: From Wyss and Koyanagi (1992).

Depth of hypocenter $5-8 \mathrm{~km}$.

Comments: 5 km from Endo (1985); 8 km from Wyss and Koyanagi (1992).

Sense of movement Right-lateral strike-slip.

Comments: A N. $59^{\circ}$ E., $60^{\circ}$ SE. nodal plane from the focal-mechanism solution for the 1974 earthquake (Endo, 1985) trends parallel to the mapped ground rupture (Jackson and others, 1992). The left-stepping en echelon array of fractures in conjunction with the focal-mechanism solution suggests that the earthquake generated right-lateral strike-slip motion (Jackson and others, 1992).

Dip $60^{\circ} \mathrm{SE}$.

Comments: Dip of the fault plane is based on focal-mechanism solutions from the 1974 earthquake (Endo, 1985; Jackson and others, 1992).

Maximum slip at surface $0.34 \mathrm{~m}$.

Comments: Cracks on new, non-reactivated crack segments from the $1974 \mathrm{Ka}$ 'öiki earthquake have a total displacement of as much as $34 \mathrm{~cm}$ (Jackson and others, 1992). 
Geophysical average slip Not reported.

Length of surface rupture $2.2 \mathrm{~km}$.

Comments: Jackson and others (1992) report a 2.2-km-long ground rupture trending N. 53 E. Jackson and others (1992) describe the ground rupture as being “....composed of seven 100- to 200-m-long, left-stepping, en echelon arrays of cracks... These arrays range up to $50 \mathrm{~m}$ in length and they strike N. $80^{\circ}-100^{\circ}$ E., about $30^{\circ}-50^{\circ}$ clockwise from the overall trend of the rupture. The arrays form two 600- to 700-m-long crack structures with a 100-m-wide left step between them" (p. 8,785).

\section{References}

Endo, E.T., 1985, Seismotectonic framework for the southeast flank of Mauna Loa volcano, Hawaii: Seattle, University of Washington, Ph.D. dissertation, 349 p.

Jackson, M.D., Endo, E.T., Delaney, P.T., Árnadottir, T., and Rubin, A.M., 1992, Ground ruptures of the 1974 and 1983 Kaoiki earthquakes, Mauna Loa Volcano, Hawaii: Journal of Geophysical Research, v. 97, no. B6, p. 8,775-8,796.

Wyss, M., and Koyanagi, R.Y., 1992, Isoseismal maps, macroseismic epicenters, and estimated magnitudes of historic earthquakes in the Hawaiian Islands: U.S. Geological Survey Bulletin 2006, 93 p.

\section{November 29, 1975, Kalapana Earthquake}

Name of earthquake Kalapana.

Comments: The 1975 Kalapana earthquake is the second largest historic earthquake to strike Hawai' ${ }^{\circ}$, surpassed only by the approximately M7.9 Great Ka'ū earthquake of 1868 (Wyss and Koyanagi, 1992).

Affected Structure Kîlauea Volcano [2608], Koa'e fault system [2609], and the following faults of the Hilina fault system [2610]: Kūkalau'ula Pali [2610b], Hilina Pali [2610c], Keana Bihopa [2610d], Pu'u Ka'one [2610e], Poliokeawe Pali [2610j], Hōlei Pali [26101], and 'Āpua Pali [2610m]. Probable surface rupture of the following faults: both traces of Pu'u Mo'o [2610a], Pu'u Kapukapu [2610f], Makahanu Pali [2610g], Pu'u'eo Pali [2610h], Kīpukapapālinamoku, [2610i], 'Āinahou [2610k], Paliuli [2610n], and Pūlama pali [2610o].

Date of earthquake November 29, 1975, 4:48 a.m. Hawaiian Standard Time (Tilling and others, 1976).

Date of compilation September 16, 2006.

Compiler and affiliation Eric C. Cannon; Roland Bürgmann, University of California Berkeley.

Magnitude or intensity M7, $\mathrm{M}_{\mathrm{s}} 7.2, \mathrm{M}_{\mathrm{w}} 7.7$ (mainshock), VIII.

Comments: M7 from Tilling and others (1976), M 7.2 from Wyss and Koyanagi (1992), M $_{w} 7.7$ from Nettles and Ekström (2004), and Modified Mercalli intensity from Tilling and others (1976). In the ten-minute period after the mainshock, a tsunami struck the south flank coast reaching $14.6 \mathrm{~m}$ maximum height $1.5 \mathrm{~km}$ east of Halapē. Between 5:32 a.m. and approximately 10:00 p.m., a sporadic eruption occurred on the floor of Kîlauea's caldera. Prior the mainshock, a M5.7 foreshock occurred at 3:36 a.m. (Tilling and others, 1976).

Moment magnitude or seismic moment Estimates range from $\mathrm{M}_{0}=1.2 \times 10^{20}$ to $4.1 \times 10^{20} \mathrm{Nm}$.

Comments: The smaller seismic moment from Furumoto and Kovach (1979) is based a 2,200 $\mathrm{km}^{2}$ fault area, rigidity of

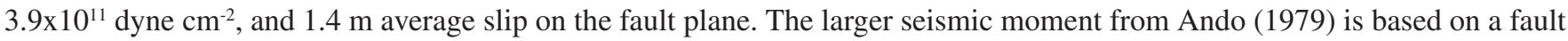
length of $40 \mathrm{~km}$, fault width of 20-30 km, rigidity of 4.0x10 11 dyne $\mathrm{cm}^{-2}$, and 3.7-5.5 m of average slip on the fault plane. Both seismic moment estimates are from analysis of P-wave data from the earthquake.

Furumoto and Kovach (1979) calculated a seismic moment of $1.2 \times 10^{27}$ dyne $\mathrm{cm}\left(1 \mathrm{dyne} \mathrm{cm}=10^{-7} \mathrm{~N} \mathrm{~m}\right)$ based on a fault area of $2,200 \mathrm{~km}^{2}$, a rigidity of $3.9 \times 10^{11}$ dyne $\mathrm{cm}^{-2}$, and an average slip of $1.4 \mathrm{~m}$ on the fault plane. Ando (1979) calculated $1.8 \times 10^{27}$ dyne $\mathrm{cm}$ for the seismic moment using a fault length of $40 \mathrm{~km}$, a fault width of $20-30 \mathrm{~km}$, a rigidity of $4.0 \times 10^{11} \mathrm{dyne}_{\mathrm{cm}}^{-2}$, and an average slip of 3.7-5.5 m on the fault plane. Furumoto and Kovach (1979) and Ando (1979) both analyzed P-wave data from the earthquake. Nettles and Ekström (2004) completed a centroid-moment-tensor analysis of the long-period body waves and estimated $3.8 \times 10^{20} \mathrm{~N} \mathrm{~m}\left(\mathrm{M}_{\mathrm{w}} 7.7\right)$ using a fault area of $1,600 \mathrm{~km}^{2}$ fault, a shear modulus of $3 \times 10^{10} \mathrm{~N} \mathrm{~m}{ }^{-2}$, and an average total slip of $7.1 \mathrm{~m}$ on the fault plane. Owen and Bürgmann (2006) analyzed geodetic data and obtained 3.6x10 $20 \mathrm{~N} \mathrm{~m}$ and 
$4.1 \times 10^{20} \mathrm{~N}$ m based on uniform slip and distributed slip models of surface deformation, respectively. Their models account for slip on the basal detachment, opening of the east rift zone [2608b] and southwest rift zone [2608c], and a summit eruption and collapse of the summit magma chamber, but do not include faults of the Hilina fault system. To account for the surface deformation detected on the Hilina fault system, the mainshock could have triggered shallow slumping that resulted in the faulting.

Location of epicenter $19^{\circ} 20.1^{\prime}$ N., $155^{\circ} 01.4^{\prime}$ W.

Comments: From Tilling and others (1976).

Depth of hypocenter Approximately $5-6 \mathrm{~km}$.

Comments: Approximately 5 km (Tilling and others, 1976), approximately 5-6 km (Lipman and others, 1985).

\section{Sense of movement SE.}

Comments: Overall southeast motion of the south flank. The focal-mechanism solution of the mainshock is controversial. Furumoto and Kovach (1979) concluded that the fault plane had an attitude of N. $64^{\circ}$ E., $04^{\circ} \mathrm{NW}$ (resulting in a low-angle thrust faulting event). Ando (1979) concluded that the fault-plane attitude was N. $70^{\circ}$ E., $20^{\circ} \mathrm{SSE}$ (resulting in low-angle normal faulting event). Nettles and Ekström (2004) obtained a fault plane of N. $64^{\circ}$ E., $09^{\circ} \mathrm{NW}$, similar to that of Furomoto and Kovach (1979). Refer to Nettles and Ekström (2004) for a complete discussion of focal-mechanism studies. Each of these focal mechanisms is consistent with southeast movement of the south flank.

Dip $04^{\circ} \mathrm{NW}, 09^{\circ} \mathrm{NW}, 20^{\circ} \mathrm{SSE}$.

Comments: Dip values for slip at the hypocenter; $04^{\circ} \mathrm{NW}$ from Furumoto and Kovach (1979), $09^{\circ} \mathrm{NW}$ from Nettles and Ekström (2004), 20 SSE from Ando (1979).

Maximum slip at surface Approximately $3.3 \mathrm{~m}$.

Comments: Total maximum slip on Hōlei Pali [26101] is based on 16 offset measurements from Mauna Ulu pāhoehoe lava flows (1969-1974) on a traverse across the Hōlei Pali fault scarp (Cannon and Bürgmann, 2001; Cannon and others, 2001).

Geophysical average slip $1.4 \mathrm{~m}, 3.7$ to $5.5 \mathrm{~m}, 7.1 \mathrm{~m}$.

Comments: $1.4 \mathrm{~m}$ slip (Furumoto and Kovach, 1979); 3.7-5.5 m pure normal dip slip (Ando, 1979); $7.1 \mathrm{~m}$ average total slip (Nettles and Ekström, 2004); $7.1 \mathrm{~m}$ slip on the dislocation representing the basal detachment in the uniform slip model (Owen and Bürgmann, 2006). Ma and others (1999) used $5.5 \mathrm{~m}$ of slip when modeling tsunami and geodetic data.

\section{Length of surface rupture $45 \mathrm{~km}$.}

Comments: Length determined from Tilling and others (fig. 16, 1976). From detailed fracture mapping, Cannon and Bürgmann (2001) measured more than $18 \mathrm{~km}$ of fractures along $6.6 \mathrm{~km}$ of fault trace.

\section{References}

Ando, M., 1979, The Hawaii earthquake of November 29, 1975-Low dip angle faulting due to forceful injection of magma: Journal of Geophysical Research, v. 84, no. B13, p. 7,616-7,626.

Cannon, E.C., and Bürgmann, R., 2001, Prehistoric fault offsets of the Hilina fault system, south flank of Kilauea Volcano, Hawaii: Journal of Geophysical Research, v. 106, no. B3, p. 4,207-4,219.

Cannon, E.C., Bürgmann, R., and Owen, S.E., 2001, Shallow normal faulting and block rotation associated with the 1975 Kalapana earthquake, Kilauea Volcano, Hawaii: Bulletin of the Seismological Society of America, v. 91, no. 6, p. 1,553-1,562.

Furumoto, A.S., and Kovach, R.L., 1979, The Kalapana earthquake of November 29, 1975-An intra-plate earthquake and its relation to geothermal processes: Physics of the Earth and Planetary Interiors, v. 18, p. 197-208.

Lipman, P.W., Lockwood, J.P., Okamura, R.T., Swanson, D.A., and Yamashita, K.M., 1985, Ground deformation associated with the 1975 magnitude-7.2 earthquake and resulting changes in activity of Kilauea Volcano, Hawaii: U.S. Geological Survey Professional Paper 1276, 45 p.

Ma, K.-F., Kanamori, H., and Satake, K., 1999, Mechanism of the 1975 Kalapana, Hawaii, earthquake inferred from tsunami data: Journal of Geophysical Research, v. 104, no. B6, p. 13,153-13,167.

Nettles, M., and Ekström, G., 2004, Long-period source characteristics of the 1975 Kalapana, Hawaii, earthquake: Bulletin of the Seismological Society of America, v. 94, no. 2, 422-429.

Owen, S.E., and Bürgmann, R., 2006, An increment of volcano collapse-Kinematics of the 1975 Lalapana, Hawaii, earthquake: Journal of Volcanology and Geothermal Research, v. 104, no. 1, p. 163-185. 
Tilling, R.I., Koyanagi, R.Y., Lipman, P.W, Lockwood, J.P., Moore, J.G., and Swanson, D.A., 1976, Earthquake and related catastrophic events, Island of Hawaii, November 29, 1975-A preliminary report: U.S. Geological Survey Circular 740, 33 p. Wyss, M., and Koyanagi, R.Y., 1992, Isoseismal maps, macroseismic epicenters, and estimated magnitudes of historic earthquakes in the Hawaiian Islands: U.S. Geological Survey Bulletin 2006, 93 p.

\section{November 16, 1983, Ka'ōiki Earthquake}

Name of earthquake Ka'ōiki.

Comments: This name is based on the location given by Wyss and Koyanagi (1992). The focal mechanisms for the 1962, 1974, and $1983 \mathrm{Ka}$ 'ōiki earthquakes are similar and are interpreted to represent right-lateral strike-slip motion on northeast-trending faults (Endo, 1985; Jackson and others, 1992).

Affected structures The Ka'ōiki seismic zone [2606] and southwest rift zone of Kīlauea Volcano [2608c]; possibly the Ka'ōiki-Honu'apo fault system [2607].

Date of earthquake November 16, 1983, 6:13 a.m. Hawaiian Standard Time (Wyss and Koyanagi, 1992).

Date of compilation September 16, 2006.

Compiler and affiliation Eric C. Cannon; Roland Bürgmann, University of California Berkeley.

Magnitude or intensity $M_{L} 6.6, M_{S} 6.6$, IX.

Comments: Surface-wave magnitude and Modified Mercalli intensity from Wyss and Koyanagi (1992). Local magnitude from the National Earthquake Information Service stated in Jackson and others (1992).

Moment magnitude or seismic moment $\mathrm{M}_{0}=0.6 \times 10^{19} \mathrm{~N} \mathrm{~m}, 1.2 \times 10^{19} \mathrm{~N} \mathrm{~m}$ Comments: Jackson and others (1992) determine the moment magnitude estimate of $M_{0}=0.6 \times 10^{19} \mathrm{~N}$ m based on a fault area of $130 \mathrm{~km}^{2}$, an average displacement of $1.5 \mathrm{~m}$ on the fault plane, and an average shear modulus of $30 \mathrm{GPa}$. The National Earthquake Information Service estimate of $\mathrm{M}_{0}=1.2 \times 10^{19} \mathrm{~N}$ m is a teleseismically-determined seismic moment (cited in Jackson and others, 1992).

Location of epicenter $19.43^{\circ} \mathrm{N} ., 155.45^{\circ} \mathrm{W}$.

Comments: From Wyss and Koyanagi (1992).

Depth of hypocenter $11 \mathrm{~km}$.

Comments: From Jackson and others (1992) and Wyss and Koyanagi (1992).

Sense of movement N. $47^{\circ}$ E.

Comments: The N. $47^{\circ}$ E. strike of the nodal plane for the mainshock focal mechanism is similar to the general N. $48^{\circ} \mathrm{E}$. to N. $55^{\circ}$ E. trend of mapped surface ruptures (Endo, 1985; Jackson and others, 1992).

Dip Vertical.

Comments: From Endo (1985), cited in Jackson and others (1992).

Maximum slip at surface $0.45 \mathrm{~m}$.

Comments: Jackson and others (1992) estimate that $0.45 \mathrm{~m}$ of maximum displacement occurred in the surficial rupture zone.

Geophysical average slip $1.5 \mathrm{~m}$.

Comments: Jackson and others (1992) calculate $1.5 \mathrm{~m}$ of average displacement at depth from the trilateration network in the Ka'ōiki area and discuss their methods in their appendix.

Length of surface rupture Greater than $7 \mathrm{~km}$.

Comments: For the Ka'ōiki-Honu'apo fault system [2607], Jackson and others (1992) state that ground cracks extended over $7 \mathrm{~km}$ along an average trend of N. $56^{\circ}$ E. Individual left-stepping cracks extended as much as $20 \mathrm{~m}$ with an average trend of 
N. $96^{\circ}$ E. Individual cracks are grouped into left-stepping en echelon arrays $25-150 \mathrm{~m}$ in length with a N. $86^{\circ}$ E. average trend. These arrays can then be grouped into several larger structures $300-900 \mathrm{~m}$ long that have an average trend of N. $65^{\circ} \mathrm{E}$. Jackson and others (1992) observed that the larger structures left step "more or less continuously" along the surface rupture with little overlap. For Kīlauea's caldera [2608a], induced ground shaking produced ground failures on steep slopes and movement on preexisting fractures, but did not produce new faulting on the caldera-concentric faults. Wyss and Koyanagi (1992) report numerous instances of ground cracking on roads in Hawai ‘i Volcanoes National Park: Crater Rim Drive, Kīlauea Military Camp, Chain of Craters, 'Āinahou Ranch, Hilina Pali, and Mauna Loa roads. Buchanan-Banks (1987) provide detailed descriptions of structural damage and ground failure resulting from the earthquake in southeastern Hawai' $\mathrm{i}$.

\section{References}

Buchanan-Banks, J.M., 1987, Structural damage and ground failures from the November 16, 1983, Kaoiki earthquake, Island of Hawaii, in Decker, R.W., Wright, T.L., and Stauffer, P.H., eds., Volcanism in Hawaii: U.S. Geological Survey Professional Paper 1350, v. 2, p. 1,187-1,220.

Endo, E.T., 1985, Seismotectonic framework for the southeast flank of Mauna Loa volcano, Hawaii: Seattle, University of Washington, Ph.D. dissertation, 349 p.

Jackson, M.D., Endo, E.T., Delaney, P.T., Árnadottir, T., and Rubin, A.M., 1992, Ground ruptures of the 1974 and 1983 Kaoiki earthquakes, Mauna Loa Volcano, Hawaii: Journal of Geophysical Research, v. 97, no. B6, p. 8,775-8,796.

Wyss, M., and Koyanagi, R.Y., 1992, Isoseismal maps, macroseismic epicenters, and estimated magnitudes of historic earthquakes in the Hawaiian Islands: U.S. Geological Survey Bulletin 2006, 93 p.

\section{June 25, 1989, Kalapana Earthquake}

Name of earthquake Kalapana.

Comments: The name is based on the location given by Wyss and Koyanagi (1992).

Affected structures Possibly the Hilina fault system [2610] on the eastern end of the Paliuli section [2610n] or the eastern end of the Pūlama pali section [2610o].

Date of earthquake June 25, 1989, 5:27 p.m. Hawaiian Standard Time (Wyss and Koyanagi, 1992).

Date of compilation September 16, 2006.

Compiler and affiliation Eric C. Cannon; Roland Bürgmann, University of California Berkeley.

Magnitude or intensity VII.

Comments: Modified Mercalli intensity (Wyss and Koyanagi, 1992).

Moment magnitude or seismic moment $\mathrm{M}_{\mathrm{L}} 6.1$.

Comments: From Wyss and Koyanagi (1992).

Location of epicenter $19.36^{\circ} \mathrm{N} ., 155.03^{\circ} \mathrm{W}$.

Comments: From Wyss and Koyanagi (1992).

Depth of hypocenter $9 \mathrm{~km}$.

Comments: From Wyss and Koyanagi (1992).

Sense of movement Not reported.

Dip Not reported. 
Maximum slip at surface $1-12$ inches $(2.5-30 \mathrm{~cm})$.

Comments: Wyss and Koyanagi (1992) state, "Ground breakage occurred with about 1-ft widening on preexisting cracks across coast road at Kalapana; inch-wide ground cracks cross Chain of Craters Road about 3 km west of Kalapana (between Kalapana and Kapa'ahu)" (p. 87). The ground deformation described by Wyss and Koyanagi (1992) may correlate with the east-striking normal faults identified approximately $1 \mathrm{~km}$ south of Kalapana (Wolfe and Morris, 1996; Trusdell and others, 2006). The fault traces indicate hanging-wall blocks down to the north. This region can be considered the eastern end of either the Paliuli [2610n] or Pūlama pali [2610o] fault. In addition, Wyss and Koyanagi (1992) state that road damage occurred in the town of Volcano and on the Volcano Road (Highway 11). For the east rift zone of Kîlauea [2608b], the Kea'au-Heiheiahulu baseline across the east rift zone extended approximately $20 \mathrm{~cm}$, probably as a result of the earthquake (Wyss and Koyanagi, 1992; Delaney and others, 1998).

\section{Geophysical average slip Not reported.}

Length of surface rupture Not reported.

\section{References}

Delaney, P.T., Denlinger, R.P., Lisowski, M., Miklius, A., Okubo, P.G., Okamura, A.T., and Sako, M.K., 1998, Volcanic spreading at Kilauea, 1976-1996: Journal of Geophysical Research, v. 103, no. B8, p. 18,003-18,023.

Trusdell, F.A., Wolfe, E.W., and Morris, J., 2006, Digital database of the geologic map of the island of Hawai 'i: U.S. Geological Survey Data Series 144, supplement to Miscellaneous Investigations Series Map I-2524-A, 18 p., 1 sheet, s cale $1: 100,000$.

Wolfe, E.W., and Morris, J., 1996, Geologic map of the island of Hawaii: U.S. Geological Survey Miscellaneous Investigations Series Map I-2524-A, 18 p., 3 sheets, scale 1:100,000.

Wyss, M., and Koyanagi, R.Y., 1992, Isoseismal maps, macroseismic epicenters, and estimated magnitudes of historic earthquakes in the Hawaiian Islands: U.S. Geological Survey Bulletin 2006, 93 p. 


\section{ॠUSGS}

U.S. DEPARTMENT OF THE NTERIOR
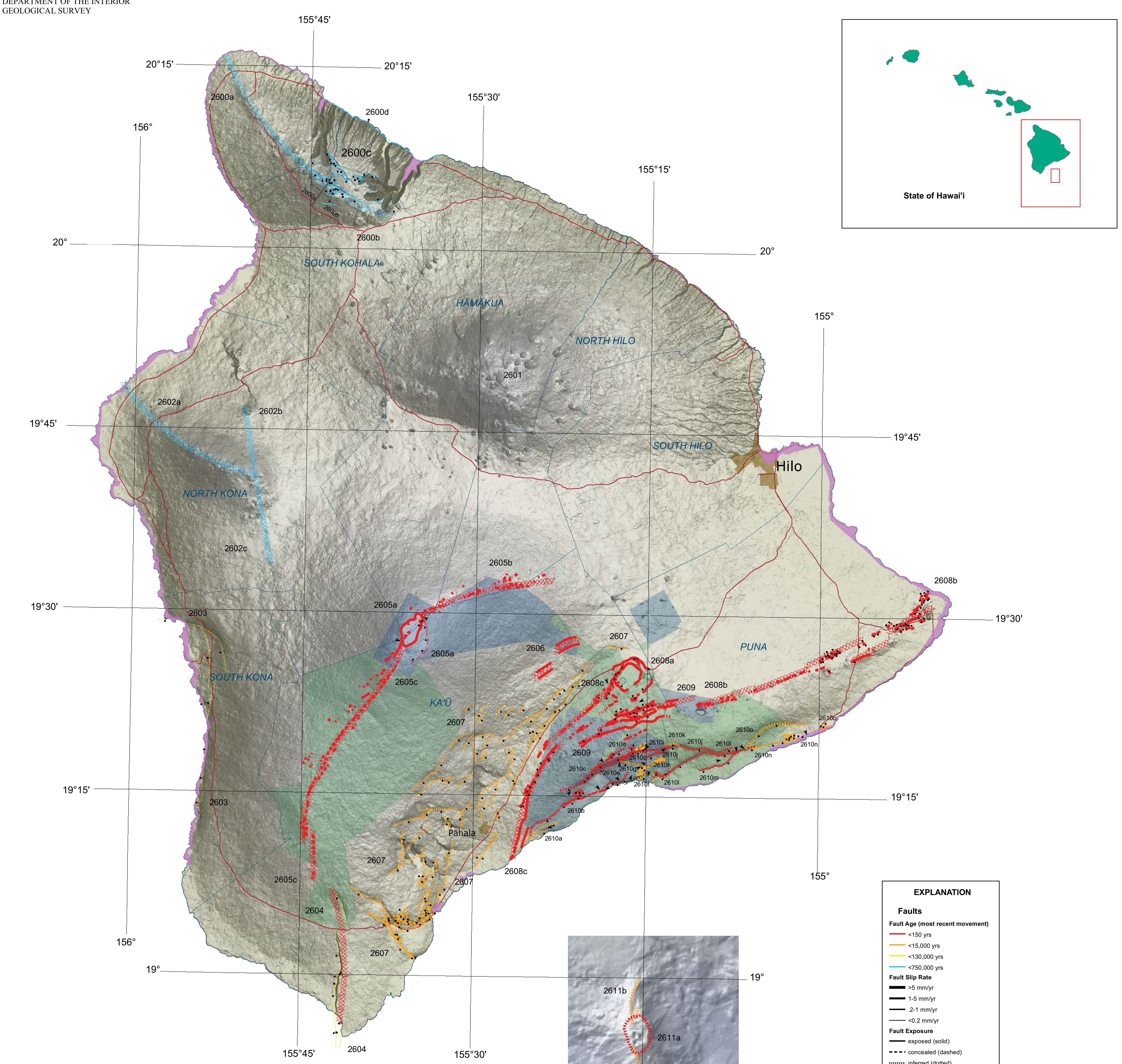

\begin{tabular}{|c|c|c|c|}
\hline No. & Name of structure & MRE & SR \\
\hline 2600 & \begin{tabular}{|l} 
Kohala Volcano \\
\end{tabular} & & \\
\hline $2600 \mathrm{a}$ & Northwest volcanic lineament & $<750 \mathrm{ka}$ & $<0.2$ \\
\hline $2600 \mathrm{~b}$ & Southeast volcanic lineament & $>750 \mathrm{ka}$ & \\
\hline & Kohala graben section & $<750 \mathrm{ka}$ & $<0.2$ \\
\hline $2600 \mathrm{~d}$ & Kohala headwall section & $<750 \mathrm{ka}$ & $<0.2$ \\
\hline 2601 & Mauna Kea Volcano & $<1.6 \mathrm{Ma}$ & $<0.2$ \\
\hline 2602 & Hualälai Volcano & & \\
\hline $2602 \mathrm{a}$ & Northwest volcanic lineament & $<750 \mathrm{ka}$ & $<0.2$ \\
\hline $2602 \mathrm{~b}$ & North volcanic lineament & $<750 \mathrm{ka}$ & $<0.2$ \\
\hline $2602 \mathrm{c}$ & South-southeast volcanic lineament & $<750 \mathrm{ka}$ & $<0.2$ \\
\hline 2603 & Kealakekua fault system & $<130 \mathrm{ka}$ & $<0.2$ \\
\hline 2604 & Kahuku fault system & $<130 \mathrm{ka}$ & $<0.2$ \\
\hline & Mauna Loa Volcano & & \\
\hline $2605 \mathrm{a}$ & Moku`āweoweo caldera & Historic (1880-1984) & $>5$ \\
\hline $2605 \mathrm{~b}$ & Northeast rift zone & Historic (1843-1984) & $>5$ \\
\hline $2605 \mathrm{c}$ & Southwest rift zone & Historic (1868-1984) & $>5$ \\
\hline & & Historic $(1974,1983)$ & $>5$ \\
\hline 2607 & 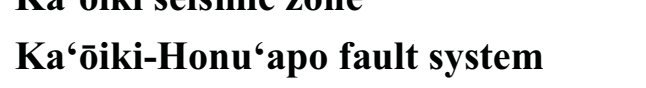 & $<15 \mathrm{ka}$ & $1-5$ \\
\hline 2608 & Kilauea Volcano & & \\
\hline $2608 \mathrm{a}$ & Kïlauea’s caldera & $<15 \mathrm{ka}$ & $>5$ \\
\hline $2608 \mathrm{~b}$ & East rift zone & Historic (1989) & $>5$ \\
\hline $2608 \mathrm{c}$ & Southwest rift zone & Historic (1983) & $>5$ \\
\hline 2609 & Koa'e fault system & Historic (1975) & $>5$ \\
\hline 2610 & Hilina fault system & & \\
\hline $2610 \mathrm{a}$ & Pưu Mo'o section & $<15 \mathrm{ka}$ & $1-5$ \\
\hline $2610 \mathrm{~b}$ & Kīkalauu ulla Pali section & Historic (1975) & $1-5$ \\
\hline $2610 \mathrm{c}$ & Hilina Pali section & Historic (1975) & $>5$ \\
\hline 2610d & Keana Bilopa section & Historic (1975) & $1-5$ \\
\hline $2610 \mathrm{e}$ & Pưu Ka' Kone section & Historic (1975) & $1-5$ \\
\hline $2610 \mathrm{f}$ & Pưu Kapukapu section & $<15 \mathrm{ka}$ & \\
\hline $2610 \mathrm{~g}$ & Makahanu Pali section & $<15 \mathrm{ka}$ & \\
\hline $2610 \mathrm{~h}$ & Pu'u'eo Pali section & $<15 \mathrm{ka}$ & $>5$ \\
\hline $2610 \mathrm{i}$ & Kīpukapapāilinamoku section & $<15 \mathrm{ka}$ & $1-5$ \\
\hline & Poliokeawe Pali section & Historic (1975) & $>5$ \\
\hline $2610 \mathrm{k}$ & 'Āinahou section & $<15 \mathrm{ka}$ & $1-5$ \\
\hline 26101 & Hōlei Pali section & Historic (1975) & $>5$ \\
\hline $2610 \mathrm{~m}$ & 'Āpua Pali section & Historic (1975) & $1-5$ \\
\hline & Paliuli section & $<15 \mathrm{ka}$ & $1-5$ \\
\hline & Pülama pali section & $<15 \mathrm{ka}$ & $>5$ \\
\hline & Lơơihi Seamount & & \\
\hline $2611 \mathrm{a}$ & Lō'ihi's caldera & Historic (1996) & $>5$ \\
\hline $2611 \mathrm{~b}$ & North rift zone & $<15 \mathrm{ka}$ & $>5$ \\
\hline $2611 \mathrm{c}$ & South rift zone & $<15 \mathrm{ka}$ & $>5$ \\
\hline
\end{tabular}

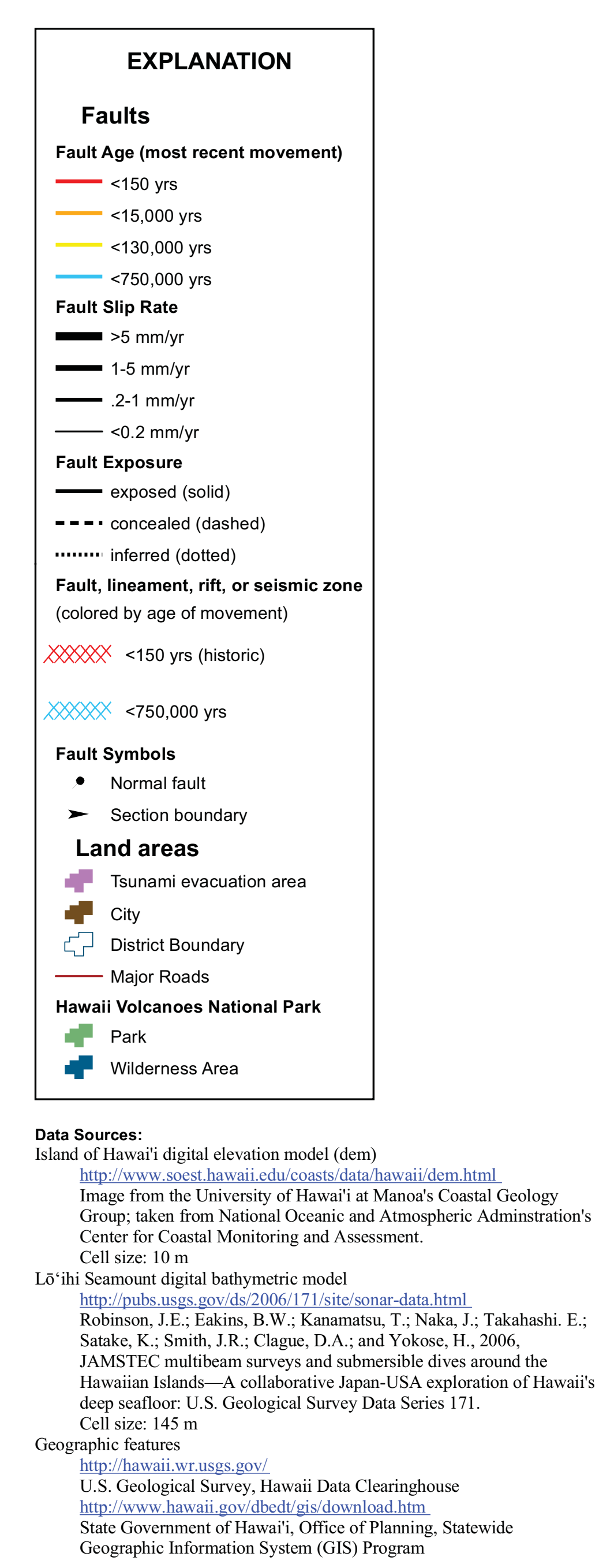

Map of Quaternary Faults and Fault Systems on the Island of Hawai'i

Eric C. Cannon, Roland Bürgmann, Anthony J. Crone, Michael N. Machette, and Richard L. Dart 2007

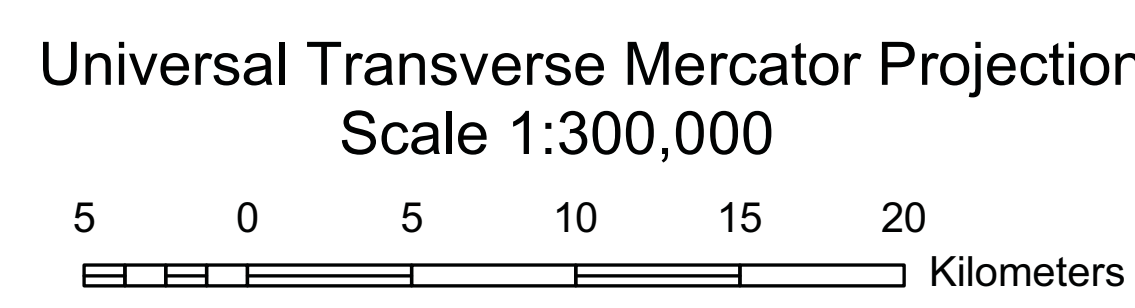

